\title{
A Geochemical and Statistical Investigation of the Big Four Springs Region in Southern Missouri
}

Jordan Jasso Vega

Missouri State University, Vega017@live.missouristate.edu

As with any intellectual project, the content and views expressed in this thesis may be considered objectionable by some readers. However, this student-scholar's work has been judged to have academic value by the student's thesis committee members trained in the discipline. The content and views expressed in this thesis are those of the student-scholar and are not endorsed by Missouri State University, its Graduate College, or its employees.

\section{Follow this and additional works at: https://bearworks.missouristate.edu/theses \\ Part of the Applied Statistics Commons, Environmental Monitoring Commons, Geology Commons, Hydrology Commons, Multivariate Analysis Commons, and the Statistical Models Commons}

\section{Recommended Citation}

Vega, Jordan Jasso, "A Geochemical and Statistical Investigation of the Big Four Springs Region in Southern Missouri" (2020). MSU Graduate Theses. 3558.

https://bearworks.missouristate.edu/theses/3558

This article or document was made available through BearWorks, the institutional repository of Missouri State University. The work contained in it may be protected by copyright and require permission of the copyright holder for reuse or redistribution.

For more information, please contact BearWorks@library.missouristate.edu. 


\title{
A GEOCHEMICAL AND STATISTICAL INVESTIGATION OF THE BIG FOUR SPRINGS REGION IN SOUTHERN MISSOURI
}

\author{
A Master's Thesis \\ Presented to \\ The Graduate College of \\ Missouri State University
}

\author{
In Partial Fulfillment \\ Of the Requirements for the Degree \\ Master of Science, Geospatial Sciences
}

By

Jordan Jasso Vega

August 2020 
Copyright 2020 by Jordan Jasso Vega 


\title{
A GEOCHEMICAL AND STATISTICAL INVESTIGATION OF THE BIG FOUR SPRINGS REGION IN SOUTHERN MISSOURI
}

Geography, Geology, and Planning

Missouri State University, August 2020

Master of Sciences

Jordan Jasso Vega

\begin{abstract}
The Big Four Springs region hosts four major first-order magnitude springs in southern Missouri and northern Arkansas. These springs are Big Spring (Carter County, MO), Greer Spring (Oregon County, MO), Mammoth Spring (Fulton County, AR), and Hodgson Mill Spring (Ozark County, MO). Based on historic dye traces and hydrogeological investigations, these springs drain an area of approximately 1500 square miles and collectively discharge an average of 780 million gallons of water per day. The rocks from youngest to oldest that are found in Big Four Springs region are the Cotter and Jefferson City Dolomite (Ordovician), Roubidoux Formation (Ordovician), Gasconade Dolomite (Ordovician), and the Eminence Dolomite (Cambrian).

The objectives of this study were to (1) establish the baseline geochemistry data of the Big Four Springs, providing insight on water-quality conditions, (2) Investigate calcite and dolomite saturation of the Big Four Springs and determine water type, (3) Determine whether the spring chemistries are significantly different from each other using a multivariate statistical approach.

The geochemical evaluation was completed using geochemical software (PHREEQC and GW_Chart). Groundwater samples from the Big Four Springs were undersaturated with respect to calcite and dolomite. The predominant water type of the study area is magnesium-calciumbicarbonate. The statistical analysis revealed that the chemistries at each spring site are significantly different from each other. The linear discriminant analysis in SAS 9.4 classified 100 percent of randomly selected groundwater samples from the study area to their respective spring locations. The statistical analysis provides insight into the independent recharge areas of the Big Four Spring Region.
\end{abstract}

KEYWORDS: karst, springs, geochemistry, groundwater, water quality, linear discriminant function analysis 


\title{
A GEOCHEMICAL AND STATISTICAL INVESTIGATION OF THE BIG FOUR SPRINGS REGION IN SOUTHERN MISSOURI
}

\author{
By \\ Jordan Jasso Vega
}

August 2020

Approved:

Douglas R. Gouzie, Ph.D., Thesis Committee Chair

Melida Gutierrez, Ph.D., Committee Member

Xiaomin Qiu, Ph.D., Committee Member

Julie Masterson, Ph.D., Dean of the Graduate College

In the interest of academic freedom and the principle of free speech, approval of this thesis indicates the format is acceptable and meets the academic criteria for the discipline as determined by the faculty that constitute the thesis committee. The content and views expressed in this thesis are those of the student-scholar and are not endorsed by Missouri State University, its Graduate College, or its employees. 


\section{ACKNOWLEDGEMENTS}

I wish to express my sincerest thanks to my thesis advisor, Dr. Douglas Gouzie for his patience and efforts during this project. His guidance and knowledge have been much appreciated. I also thank the Missouri State University Geography, Geology, and Planning Department for providing ample opportunities to expand my academic and professional development. I am grateful for the financial support provided by Missouri State University's Graduate College Research Fund and the Karst Fund.

Further, I extend my gratitude to the Missouri Geological Survey who provided the geochemical analysis for this study and provided bountiful support for my efforts.

It has been a pleasure working with the Park Rangers at the Mammoth Spring State Park and the National Park Service at Big Spring of the Ozark National Scenic Riverways. I thank the USDA National Forest Service Rangers at Greer Spring who were just as enthused with this project as I was.

Additionally, I would like to express my sincerest appreciation to my committee members, Dr. Melida Gutierrez and Dr. Xiaomin Qiu, for providing helpful suggestions, insight, and guidance in contaminant geochemistry and statistics.

I would like to express my sincerest appreciation to my family-- tia Te, tia Chata, Johnny, Ryan, Daniel, uncle Charles, and my lovely Abuelita, who encouraged me to be brave like my grandfather.

Thank you to all my friends who greatly provided me support when I needed it the most. Thank you, Breanna Birkett, and Brooke Birkett for your suggestions and support during this project.

Finally, I would like to give my special gratitude to my mother, Blanca, and my late uncle, Jose Luis, for their infinite support, encouragement, and love. 


\section{TABLE OF CONTENTS}

Introduction 1

Karst 1

Geochemistry 3

Statistics 4

Physiographic Regions of Missouri 5

Big Four Springs Region $\quad 5$

$\begin{array}{ll}\text { Purpose } & 6\end{array}$

Methods $\quad 8$

Study Area $\quad 8$

Sample Collection $\quad 12$

Laboratory Analysis $\quad 20$

Data Analysis 20

Results 25

$\begin{array}{ll}\text { Chemistry Data } & 25\end{array}$

Geochemical Evaluation $\quad 25$

Statistical Modeling $\quad 28$

Discussion $\quad 32$

Water Quality $\quad 32$

Chemical Analysis $\quad 32$

Groundwater Classification $\quad 37$

Statistical Analysis $\quad 38$

General Discussion $\quad 39$

$\begin{array}{ll}\text { Conclusion } & 46\end{array}$

$\begin{array}{ll}\text { Future Work } & 48\end{array}$

References Cited 49

Appendices 53

Appendix A. - Geochemical Data 53

Appendix B. - Statistical Data 58 


\section{LIST OF TABLES}

Table 1. Sample site GPS coordinates and elevation data.

Table 2. Generalized hydrogeologic sequence of the Big Four Springs region

Table 3. Descriptive statistics comparing Big Four Spring chemistry 26

Table 4. Calcite saturation summary statistics 28

Table 5. Dolomite saturation summary statistics 28

Table 6. KMO and Bartlett's Test results 31

Table 7. Factor analysis communalities and components results 31 


\section{LIST OF FIGURES}

Figure 1. Karst geology and hydrology 3

Figure 2. Principal physiographic regions of Missouri 7

$\begin{array}{ll}\text { Figure 3. Big Spring sample site photo } & 14\end{array}$

Figure 4. Greer Spring sample site photo 14

$\begin{array}{ll}\text { Figure 5. Mammoth Spring sample site photo } & 15\end{array}$

Figure 6. Hodgson Mill Spring sample site photo 15

Figure 7. Stratigraphic column of the Big Four Springs region 16

Figure 8. Water table DEM with dye traces of the Big Four Springs 18

Figure 9. Dye tracing map of the Big Four Region recharge area 19

Figure 10. Normal P-P plot of regression standardized residual 30

Figure 11. Nitrogen variation plot $\quad 41$

Figure 12. Conductivity variation plot $\quad 42$

Figure 13. Piper diagram-Salem Plateau springs and Springfield 42

Plateau springs

Figure 14. Calcite and dolomite saturation index box and whisker 43 graphs

Figure 15. Model one discriminant functions $\quad 44$

Figure 16. Linear discriminant scores of model one $\quad 44$

Figure 17. Model two discriminant functions $\quad 45$

Figure 18. Linear discriminant scores of model two 45 


\section{INTRODUCTION}

The Ozark aquifer is an important source of water in south-central Missouri. The water from the Ozark aquifer discharges from many karst springs in the Salem Plateau. South-central Missouri is home to more than 1,100 springs that range from small seeps and fens to first order magnitude springs (Vineyard and Feder, 1974). Springs are classified as first order-magnitude when discharge rates are greater than or equal to 100 cubic feet per second (Vineyard and Feder, 1974). As plans for future development in the area are being considered, studies on significant water resources have been a major focus for the state of Missouri.

This study is significant to Missouri residents and everyone who utilizes the Ozark aquifer in the region because it provides information about sources that influence the water quality. The data evaluated in this project provide a better understanding of the relationship between agricultural land use, regional geology, and the geochemical characteristics of the water discharging from each of the Big Four Springs. The Big Four Springs are Big Spring (Carter

County, MO), Greer Spring (Oregon County, MO), Mammoth Spring (Fulton County, AR), and Hodgson Mill Spring (Ozark County, MO). Additionally, the major springs studied in this project provide significant amounts of recharge to rivers in the Ozark National Scenic Riverways and other locally important streams that bring people from across the United States to fish, kayak, and hike.

\section{Karst}

Karst is a term used to describe a terrain characterized by distinct landforms such as sinking streams, sinkholes, caves, and springs within soluble bedrock (Figure 1). The study area 
is underlain by dolomite with some interbedded sandstones and limestone. Limestone is mostly composed of the mineral calcite $\left(\mathrm{CaCO}_{3}\right)$, whereas dolomite rocks are composed of the mineral dolomite $\left(\mathrm{MgCa}\left(\mathrm{CO}_{3}\right)_{2}\right)$. The dissolution of limestone and dolostone occurs when these rocks are exposed to mildly acidic waters (Drever, 1982). Carbonic acid is most associated with the dissolution of carbonate rocks as it forms from the hydration of atmospheric $\mathrm{CO}_{2}$ gas during precipitation events (Ford and Williams, 2007). Carbonic acid can also form from water mixing with soil $\mathrm{CO}_{2}$ gas sourced from the respiration of plant root systems (Drever, 1982).

Karst Features. Sinking streams, sinkholes, and caves are common karst features. These features can be hydrologically connected, as surface streams flow into sinkholes and continue to flow through underground cave systems. Cave systems in the Missouri Ozarks have the potential for transporting large volumes of water (Schumacher and Kleeschulte, 2010). These karst features are important for aquifer recharge and are highly susceptible to contamination as little natural filtration is done to the recharge waters. Conduit flow occurs where groundwater moves quickly, recharging the aquifer through sinkholes, fractures, and caves. Recharge also occurs diffusely in the study area, as water moves through soil and bedrock-matrix porosity (Schumacher and Kleeschulte, 2010).

Karst springs are commonly found in the Missouri Ozarks. They can range in size from small seeps to large pools which can develop into spring-fed lakes or spring-fed rivers (i.e. Spring River, AR and Mammoth Spring State Park, AR). These features provide useful information about the characteristics and dynamics of karst aquifers without having to drill through the bedrock and into the water table. 


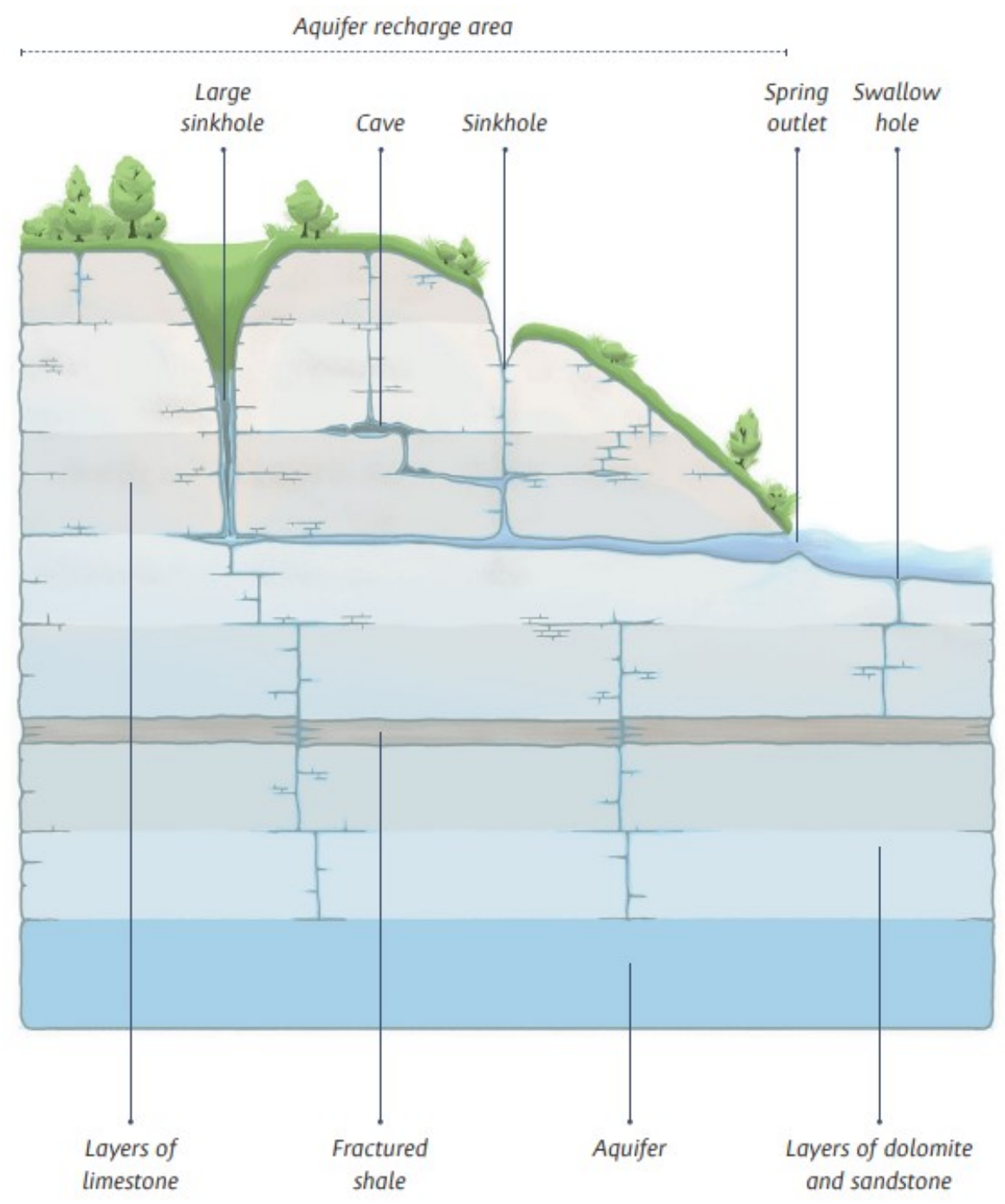

Figure 1: Illustration of karst geology and hydrology in the Ozarks (Watershed Committee of the Ozarks, 2017).

\section{Geochemistry}

Geochemical analysis of spring water has been widely used to study the characteristics and evolution of groundwater in karst systems. As it flows along a channel, it erodes rock and reacts with organic matter. These mechanisms for the transfer of solid and gaseous components are essential factors in determining the composition of groundwater (Hem, 1985).

The dissolution of carbonate rocks is the primary source of dissolved ions found in karst groundwater (Drever, 1982; Newell and others, 2008). Commonly studied ions in groundwater 
include calcium $\left(\mathrm{Ca}^{2+}\right)$, magnesium $\left(\mathrm{Mg}^{2+}\right)$, sodium $\left(\mathrm{Na}^{+}\right)$, potassium $\left(\mathrm{K}^{+}\right)$, barium $\left(\mathrm{Ba}^{2+}\right)$, and zinc $\left(\mathrm{Zn}^{2+}\right)$. Major anions measured in this study were chloride $\left(\mathrm{Cl}^{-}\right)$, sulfate $\left(\mathrm{SO}_{4}{ }^{2-}\right)$ and $\mathrm{N}$ as $\mathrm{NO}_{2}{ }^{-}+\mathrm{NO}_{3}{ }^{-}$. Ions are supplied to the aquifer via surface water infiltration and groundwater interaction with the dolomite host rock. Calcium and magnesium concentrations are due to the groundwater and aquifer rock interaction as acidic waters are dissolving dolomite. Dolomite and calcite dissolution respectively follow the equations (Drever, 1982):

$$
\begin{gathered}
\mathrm{CaMg}\left(\mathrm{CO}_{3}\right)_{2}+2 \mathrm{CO}_{2(\mathrm{aq})}+2 \mathrm{H}_{2} \mathrm{O}=\mathrm{Ca}^{2+}+\left(\mathrm{HCO}_{3}\right)_{2}+\mathrm{Mg}^{2+}+\left(\mathrm{HCO}_{3}\right)_{2} \quad \text { (dolomite) } \\
\mathrm{CaCO}_{3}+\mathrm{H}_{2} \mathrm{O}+\mathrm{CO}_{2}=\mathrm{Ca}^{2+}+2 \mathrm{HCO}_{3}^{-} \quad \text { (calcite) }
\end{gathered}
$$

The concentration of calcite and dolomite that water can dissolve is limited to the amount of dissolved $\mathrm{CO}_{2}$ in a closed system. However, dissolution largely takes place in an open system since the recharge waters from precipitation receive soil-derived $\mathrm{CO}_{2}$ gas and dissolve it into solution.

As surface waters move underground into the aquifer and out through springs, the water develops chemical signatures that depict substrates that it has encountered (Shuster and White, 1971). The geochemistry is related to the water-rock interaction that occurs along the flow path (Hanshaw and Back, 1985). Lockwood (2018) found that springs within relative proximity to each other can have unique chemical signatures.

\section{Statistics}

Statistical analysis of karst groundwater has been used to investigate different chemistries at spring locations (Jeelani and others, 2011; Lockwood, 2018). Multivariate statistical techniques, such as linear discriminant function analysis, factor analysis, principal component analysis, and linear regression analysis, have been useful in identifying origins responsible for 
variations in water quality and the grouping of similar components (Michalik, 2008; Nabi and others, 2009).

\section{Physiographic Provinces of Missouri}

There are five principal physiographic regions in Missouri (Figure 2). The Big Four Springs region is in the Salem Plateau Physiographic Province. The Salem Plateau encompasses an area of approximately 24,800 square miles (Figure 2). The Salem Plateau is one of the most significant groundwater provinces of the five in Missouri, providing much of south-central Missouri's groundwater. The St. Francois aquifer underlays the Ozark aquifer and is another significant aquifer in the Salem Plateau. However, most of the water within the study area is taken from the shallower more prolific Ozark aquifer. Of the two major aquifers, the Ozark aquifer is the most widespread and most widely used. The Ozark aquifer is approximately 800 to 1,000 feet thick, but can reach thicknesses up to approximately 3,000 feet in some locations and is unconfined in the Salem Plateau (Imes and Emmett, 1994).

\section{Big Four Springs Region}

The recharge area of Big Spring, Greer Spring, Mammoth Spring and Hodgson Mill Spring covers approximately 1,500 square miles. Elevation, county and coordinate data can be found in Table 1. Together the springs discharge groundwater at a rate of approximately 1,200 cubic feet per second (cfs) or 780 million gallons of water per day. The recharge area of the springs is referred to as the Big Four Springs Region in this study. The hydrography of the Big Four Springs Region was first investigated by Doll (1938), followed by widespread dye tracing investigations beginning with Aley (1972) to further understand groundwater flow of the Big 
Four Spring Region. The most recent dye tracing study was completed by Duley and Boswell (2017) to further delineate the recharge areas of each spring.

\section{Purpose}

The primary objective of this project is to evaluate the inorganic chemistry and water quality as it pertains to human consumption and use for future development of the region. This project does not evaluate the organic chemistry of the groundwater samples.

The secondary objective was to evaluate the water chemistry data of the Big Four Springs, classify the water type and determine the degree of calcite and dolomite saturation.

The third objective of this project was to expand previous work by Gouzie (1986) and Lockwood (2018) using membership probabilities to classify unidentified (blind) spring water samples to their respective springs. It is hypothesized that there is a significant difference in the geochemistry of the spring waters at each site, allowing them to be distinguished from each other using statistical modeling. 


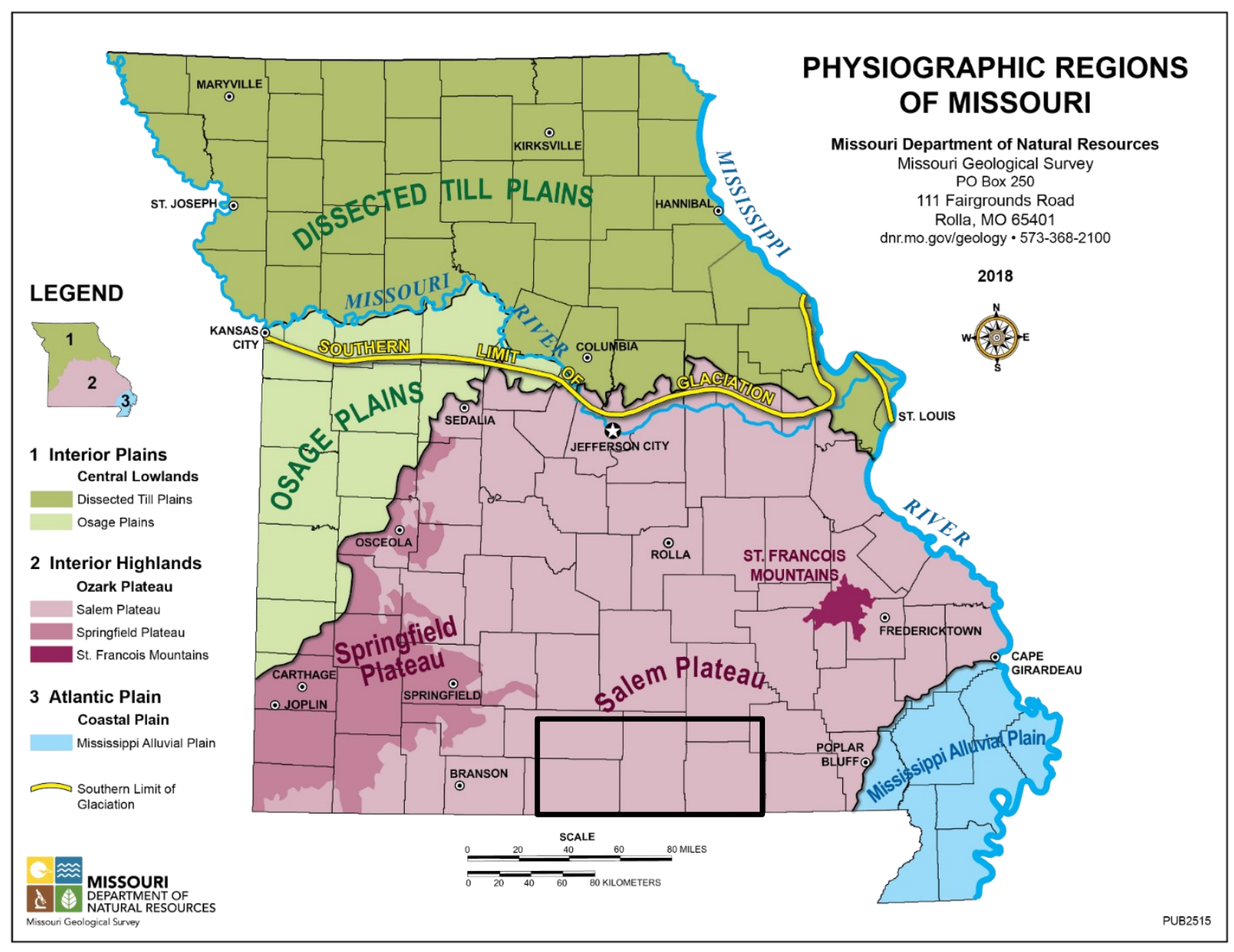

Figure 2: Principle physiographic regions of Missouri. The Big Four region spring sampling sites are located in the Salem Plateau. Study area is boxed in (black) (Missouri Geological Survey, 2018).

Table 1: GPS coordinates for each sample site (decimal degrees) and spring elevation.

\begin{tabular}{lcccc} 
Spring Name & Lat. & Long. & County & Elev. (ft) \\
\hline Big Spring & 36.952242 & -90.994290 & Carter & 433 \\
Greer Spring & 36.786605 & -91.348640 & Oregon & 519 \\
Mammoth Spring & 36.4497512 & -91.535770 & Fulton & 528 \\
Hodgson Mill Spring & 36.709710 & -92.266632 & Ozark & 656 \\
\hline
\end{tabular}




\section{METHODS}

\section{Study Area}

Big Spring. Big Spring was one of Missouri's first National Parks and is now part of the Ozark National Scenic Riverways located in Carter County. Missouri donated Big, Alley, and Round Spring State Parks to the National Park Service which became part of the Ozark National Scenic Riverways. Big Spring is the largest spring in the Ozark Plateau Region. Discharge averages about $478 \mathrm{cfs}$ with an estimated recharge area of approximately 423 square miles to the west. Big Spring is stratigraphically situated near the base of the Ozark Aquifer (Figure 3).

Greer Spring. Greer Spring is in Oregon County, Missouri (Figure 4). Greer Spring is the second largest spring in Missouri and the third largest in the Ozarks. Greer Spring discharges $369 \mathrm{cfs}$ at base flow, with an estimated recharge area of 344 square miles located to the northwest. There are two spring outlets at this spring site. The upper spring outlet was studied in this investigation.

Mammoth Spring. Mammoth Spring, located in Fulton County, Arkansas is the third largest spring in the Ozarks and the largest spring in Arkansas (Figure 5). Mammoth Spring has an average flow rate of approximately $351 \mathrm{cfs}$ with an estimated recharge area of approximately 348 square miles located to the northwest (Duley and Boswell, 2017). The spring water forms a 10-acre lake, then flows over a dam forming the Spring River.

Hodgson Mill Spring. Hodgson Mill Spring is in Ozark County, Missouri, approximately 100 miles southeast of Springfield, Missouri (Figure 6). The average discharge from Hodgson Mill Spring is 36.4 cfs. It has an estimated recharge area of approximately 15 square miles, located to the northwest of the Bryant Creek watershed. Hodgson Mill Spring is 
part of the Rainbow and North Fork Spring complex; their combined flow rate is in excess of $200 \mathrm{cfs}$. Dye tracesestablished the connectivity of the three springs (Duley and Bowell, 2017).

Geology. The surface bedrock of the study area in the Salem Plateau includes, in descending order, the Cotter and Jefferson City Dolomites (undifferentiated), Roubidoux Formation, the Gasconade Dolomite, and the Eminence Dolomite (Figure 7). The rocks of the Salem Plateau are comprised predominantly of Ordovician to Cambrian aged fractured dolomites, limestones, and shales. Cave and sinkhole distribution occurs mostly parallel to subparallel to bedding planes with higher densities of caves occurring at the Roubidoux FormationGasconade Dolomite contact and the Gasconade Dolomite-Eminence Dolomite contact (Lowell and others, 2010).

Cotter And Jefferson City Dolomite (Lower-Ordivician). The Cotter and Jefferson City Dolomite formations are undifferentiated in many parts of the Ozarks due to limited bedrock exposure. These dolomites are the host rock for Mammoth Spring (Figure 7). These formations consist of buff colored dolomite, medium to fine-grained sandstone, with white chert nodules (Hedden, 1968; Weary and others, 2014). Both the Cotter and Jefferson City Dolomites are sparsely fossiliferous. The combined thickness of both formations is approximately 400 feet. The Cotter and Jefferson City Dolomites have relatively lower hydraulic conductivities compared to the underlying dolomites. Shallow wells in the Cotter and Jefferson City dolomites yield less than 25 gallons per minute (Table 2) (Imes and Emmett, 1994). Most wells in the region penetrate deeper into the Ozark Aquifer until they reach the underlying dolomite Roubidoux Formation (Duley and Boswell, 2017).

Roubidoux Formation (lower-Ordovician). The Roubidoux Formation is a principal water-bearing formation in the study area. This is due to its increased thickness and permeability 
compared to other formations in the region (Imes and Emmett, 1994). Wells reaching the Roubidoux formation have been reported to yield 30 to 50 gallons per minute on average and can reach 150-600 gallons per minute of water from the Ozark aquifer of the Salem Plateau in some areas (Table 2) (Imes and Emmett, 1994). The lower-Ordovician Roubidoux Formation is approximately $250 \mathrm{ft}$ thick, consisting of loosely to well-cemented, poorly sorted sandstone, dolomite, sandy dolomite, and chert (Weary and others, 2014). The Roubidoux Formation makes up a significant portion of the river-cut valleys in south-central Missouri.

Gasconade Dolomite (Lower-Ordovician). The Gasconade Dolomite has been known to yield 75 gallons of water per minute on average and greater (Duley and Boswell, 2017). This significant water-bearing formation of the Ozark Aquifer is the host rock for Hodgson Mill Spring and Greer Spring (Figure 7) (Table 2). The upper-Gasconade Dolomite is medium to coarse-grained thickly-bedded, vuggy and light gray (Weary and others, 2014). The middle member contains fine to coarse grained, light-gray, dolomite with white to light-gray chert nodules (Weary and others, 2014). The lower Gasconade member contains a layer known as the Gunter Sandstone Member which consists of a loosely cemented sandstone and sandy dolomite with orthoquartzite interbedded with gray to tan, finely-grained, dolomite (Thompson, 1991; Imes and Emmett, 1994). The entire Gasconade Dolomite ranges about 150 to 300 feet in thickness (Weary and others, 2014).

Eminence And Potosi Dolomites (Upper-Cambrian). Big Spring is located within the Eminence Dolomite (Figure 7) (Duley and Boswell, 2017). The Eminence Dolomite is the basal formation of the Ozark aquifer and is undifferentiated with the Potosi Dolomite (Imes and Emmett, 1994). Together, these formations are approximately 400 feet thick in the Salem Plateau. Both dolomite formations are lithologically similar. However, in parts of the Missouri 
Ozarks, where the Potosi is differentiated from the Eminence, it is highly permeable due to interconnected vugs and solution channel systems (Imes and Emmett, 1994). Although the Eminence and Potosi Dolomites are generally permeable they are less permeable and less interconnected within the study area (Table 2) (Imes and Emmett, 1994).

Hydrology. The Ozark aquifer recharges largely from precipitation onto the Salem Plateau. The groundwater of the Ozark aquifer of the Salem Plateau is strongly influenced by the topographic features in the region (Figure 8) (Imes and Emmett, 1994). The altitude of the potentiometric surface ranges from approximately $200 \mathrm{ft}$ to $1450 \mathrm{ft}$ above sea level. Groundwater movement in this area is generally correlated to the regional topographic features. Past dye tracing injection points are in topographic and potentiometric highs. Groundwater flows towards the topographic low and potentiometric lows discharging at springs and into major rivers. During low-flow conditions, Big Spring contributes more than $30 \%$ of water to the Current River (Hays and others, 2016). The incision of the Current River exposes the Eminence and Potosi Dolomite Formation, producing relatively steep bluffs with mountainous topography and local relief of hundreds of feet (Lowell and others, 2010). Greer Spring discharges into the Eleven Point River. The incision of the Eleven Point River exposes bluffs of the Gasconade Dolomite Formation and the Gunter Sandstone. The flow pattern is topographically controlled in this region of the study area.

Dye Tracing. Previous work carried out in the Big Four Region used dye tracing techniques to understand how sinking streams and springs were connected, which established the geohydrology of the region (Aley 1975; Vandike, 1979; Mugel and others, 2009). The latest publication (Duley and Boswell, 2017) further delineated the Big Four Region and established a 
more refined recharge region for each of the major springs within the study area. Many legacy traces were confirmed in addition to new injection locations. It was confirmed that deep connecting conduits connect the region of the Eleven Point River to Big Spring on the Current River (Duley and Boswell, 2017). The same connecting conduit system also recharges Greer Spring. Also, new traces from replicated injection points revealed that the northern part of the

recharge area for Mammoth Spring is shared with Greer Spring (Figure 9). Recent studies from Duley and Boswell (2017) indicate that Greer Spring and Big Spring share recharge areas.

Recovered traces also demonstrate that flow to Greer Spring mostly occurs through openings that pass beneath a gaining segment of the Eleven Point River. Hodgson Mill Spring has its own local recharge area apart from sharing recharge from two other significant springs in relatively close proximity.

\section{Sample Collection}

Ten sampling events were completed during the summer season, from June 2019 through October 2019. Sample collection was done at the spring orifices of Hodgson Mill Spring, Mammoth Spring, Greer Spring, and Big Spring. The waters that issue from the study sites represent the primary water source for private and public use in the region. Water samples were collected at the spring orifices to minimize the effect of turbulence that would otherwise have altered the chemistry of the water by the release of $\mathrm{CO}_{2(\mathrm{aq})}$ from solution.

Water samples were taken at each sample site following standard operating procedures (SOP) provided by the Missouri Geological Survey, part of the Missouri Department of Natural Resources. Five grab samples were collected at each site, all in accordance with scientific research and collecting permits or guidelines (Big Spring; Permit\#: OZAR-0219-SCI-0001, 
Mammoth Spring; Permit 048-2019, Greer Spring; written and verbal approval from the USDA National Forest Service, and Hodgson Mill Spring; following guidelines located onsite). There were some challenges when sampling from Mammoth Spring. There was considerable vegetation and algae that inhabited the waters, about two feet from the bank of spring lake. Any attempt to collect water by using the standard grab sample technique by hand would introduce bits of algae if the water were to be disturbed. All samples at Mammoth Spring were collected using a peristaltic pump and a three meter long Tygon plastic tubing with a weight attached at the end. This technique provided sampling beyond the vegetation and algae. The spring orifices at Big Spring, Greer Spring, and Hodgson Mill Spring were easily accessible allowing for the handdipping grab sample technique.

Sampling events at each spring required collecting two $250 \mathrm{~mL}$ bottles of water for chloride and sulfate analysis, one $1000 \mathrm{~mL}$ sample preserved with concentrated sulfuric acid for Nitrogen analysis, and two $500 \mathrm{~mL}$ samples preserved with nitric acid for total recoverable and total dissolved metals. Samples used for total dissolved metals were filtered through 0.45 -micron Whatman filters attached to $100 \mathrm{ml}$ syringes dedicated to each spring location to avoid contamination. Syringes were rinsed three times using the spring water at each site before water samples were collected.

Twenty water samples were collected during each sampling event and stored at $<6^{\circ} \mathrm{C}$ at Missouri State University. The Missouri Department of Natural Resources, Environmental Services Program, provided SOP approved Nalgene bottles, concentrated nitric acid, concentrated sulfuric acid, and laboratory analyses. Water samples were delivered to the lab no more than two weeks after collection following chain of custody procedures. Results from the laboratory analysis were received approximately one month after drop-off. 


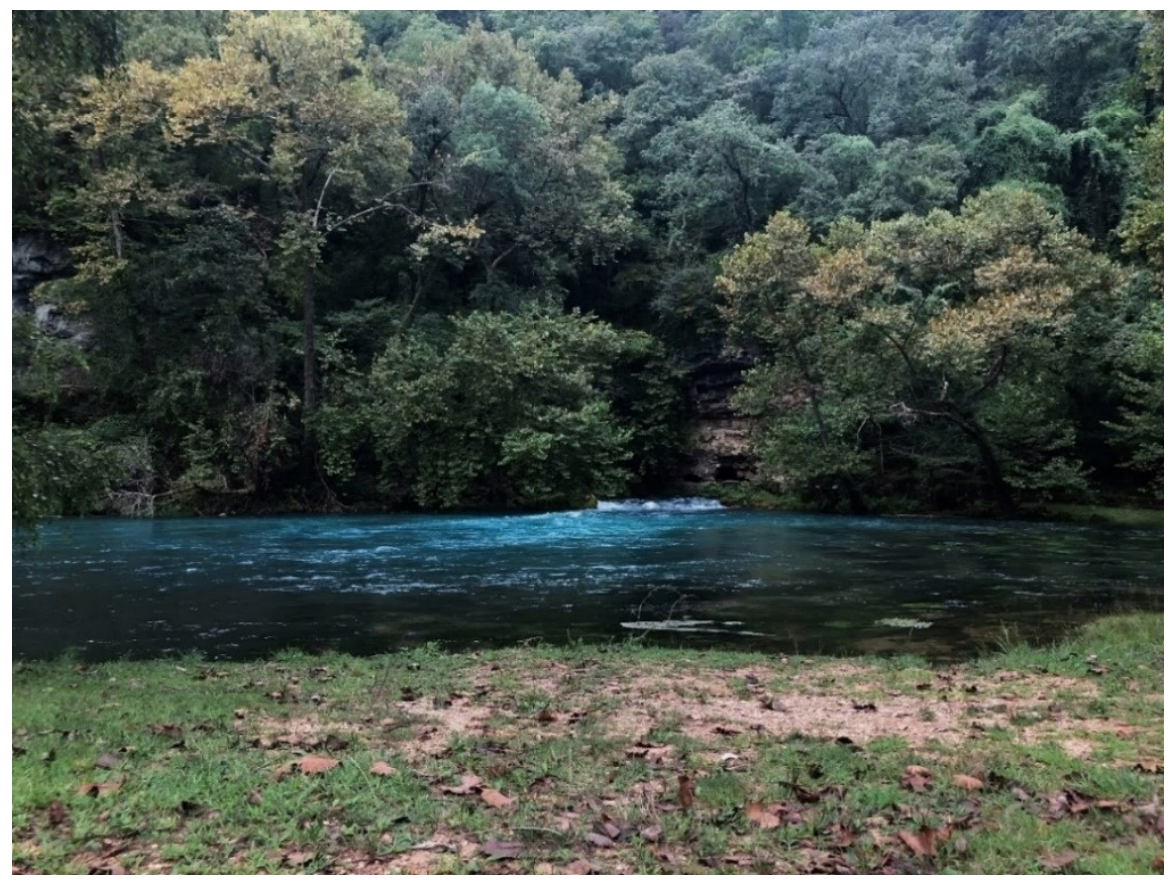

Figure 3: Sample collection site location at Big Spring. Water was collected alongside the bluff just before the rapids in the photo.

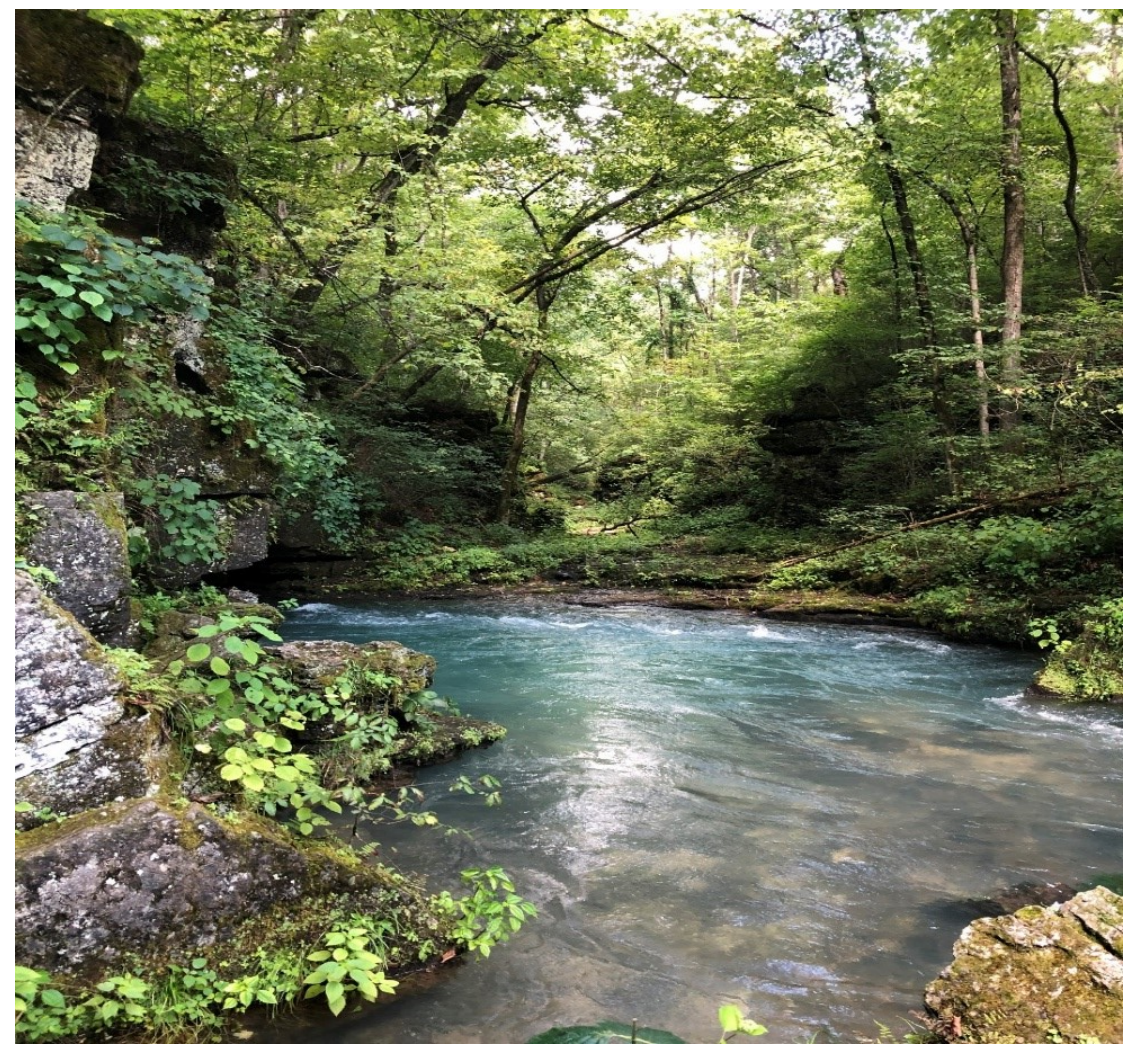

Figure 4: Sample collection site at Greer Spring near the cave entrance on the left side of the photo. 


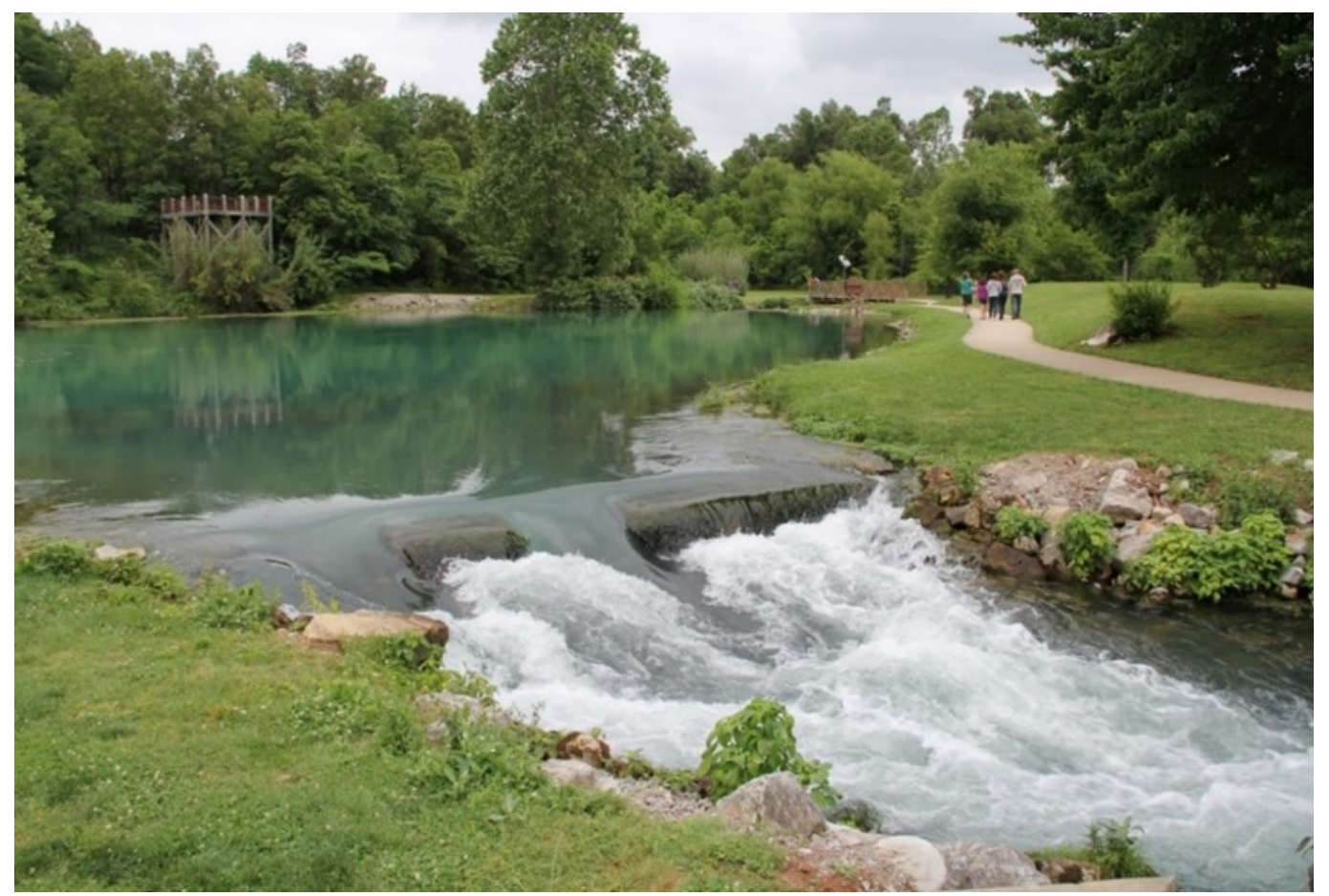

Figure 5: Sample collection site at Mammoth Spring. Samples collected at the approximate location of the visitors in the photo.

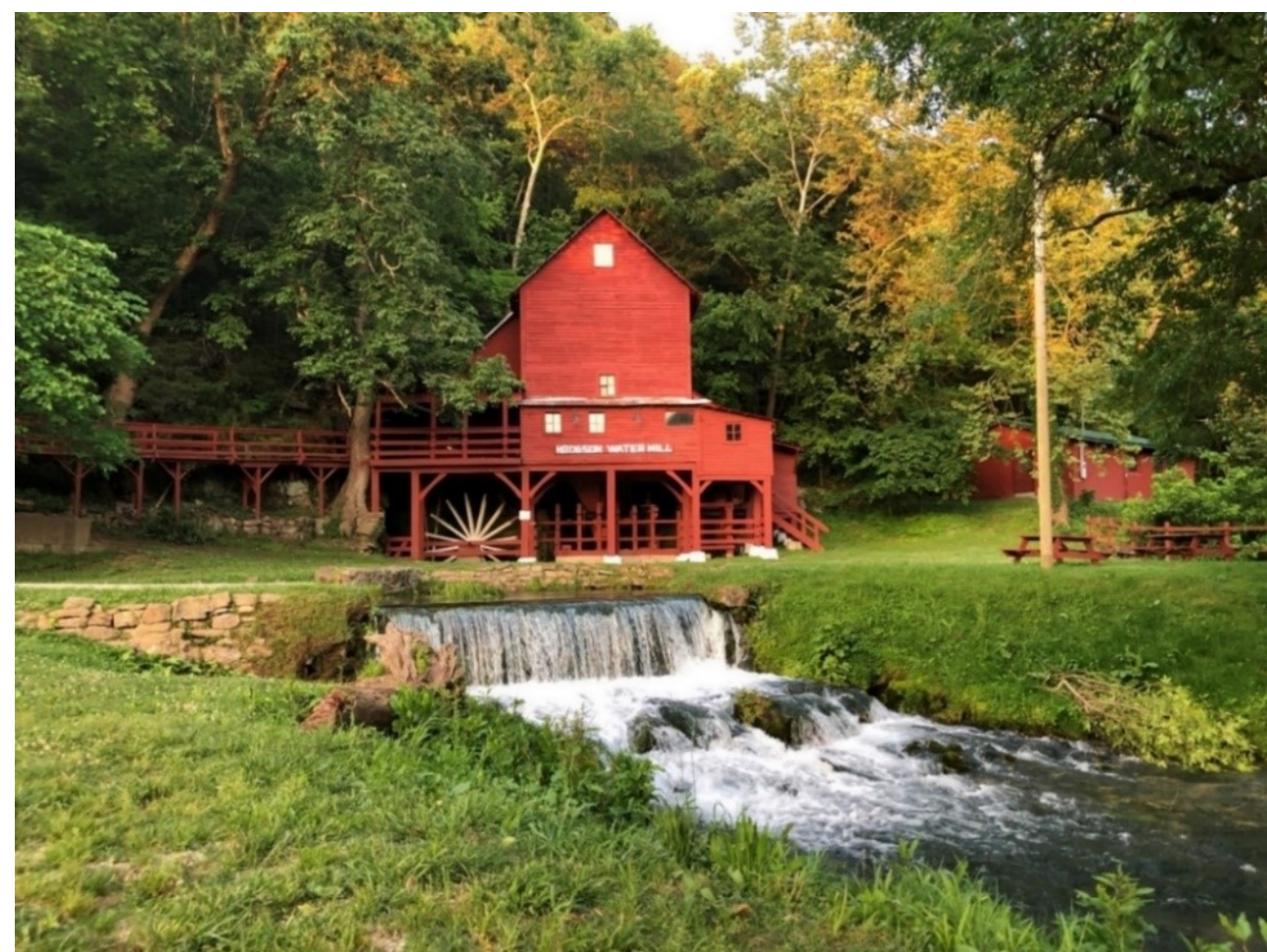

Figure 6: Sample collection site at Hodgson Mill Spring near the concrete steps left adjacent to the water wheel. 


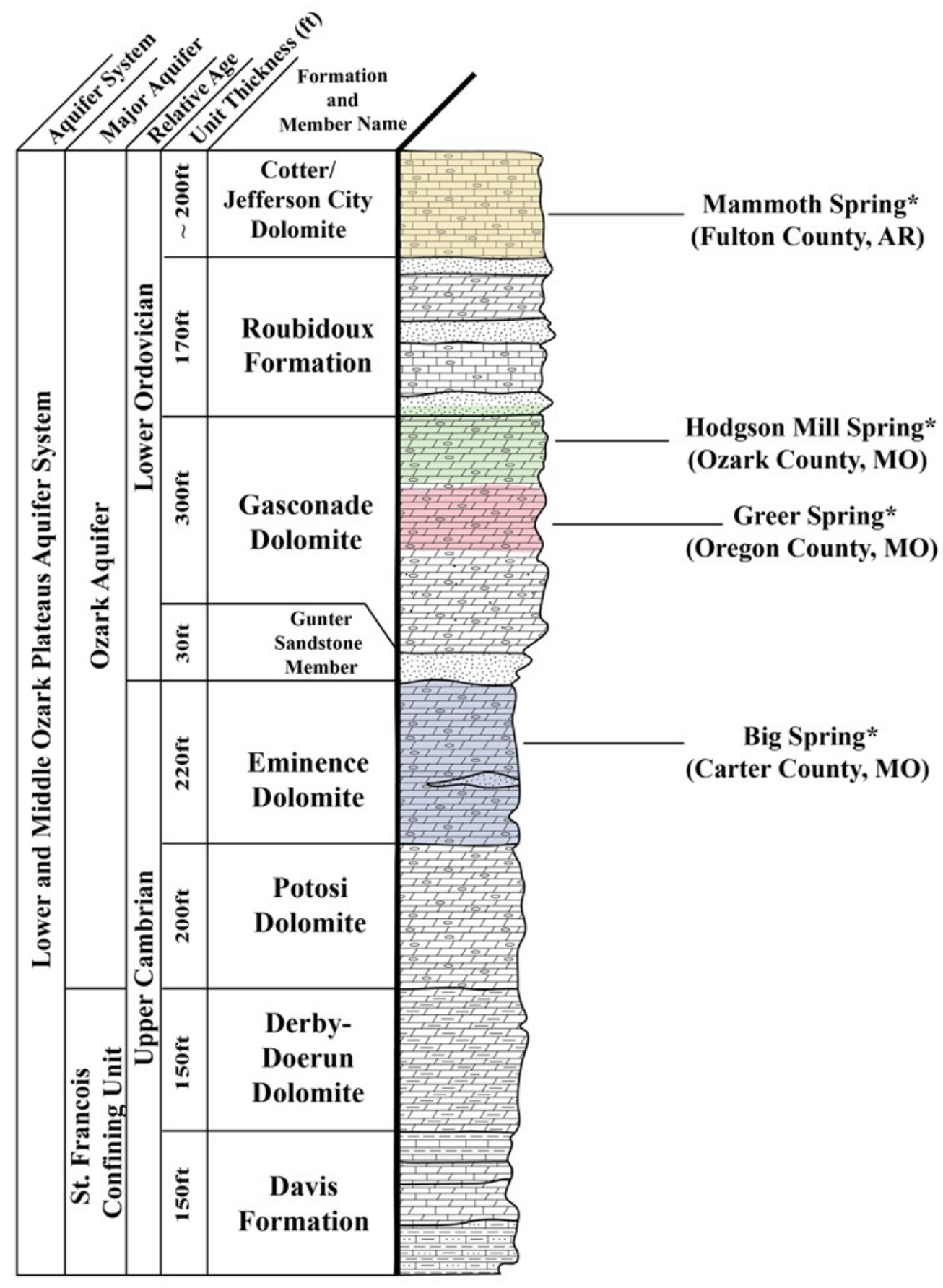

Figure 7: Stratigraphic sequence of the Big Four Springs region depicting the Lower-Ordovician and Upper-Cambrian dolomite formations that make up the Ozark aquifer. Stratigraphic column modified from Thompson (1991). 
Table 2: Generalized hydrogeologic sequence of the Big Four Springs region in the Salem Plateau.

\begin{tabular}{|c|c|c|c|c|c|c|}
\hline System & Geologic Unit & $\begin{array}{c}\text { Thickness in } \\
\text { Feet }\end{array}$ & $\begin{array}{l}\text { Lithologic } \\
\text { Character }\end{array}$ & $\begin{array}{c}\text { Hydrologic } \\
\text { Remarks/Well } \\
\text { Yield in } \\
\text { Gallons/Minute } \\
\text { (gpm) } \\
\end{array}$ & Classification & $\begin{array}{l}\text { Associated Spring } \\
\text { Orifice(s) in the } \\
\text { Study Area }\end{array}$ \\
\hline \multirow{6}{*}{ Orodvician } & Cotter Dolomite & 200 (Avg) & $\begin{array}{l}\text { Fine to medium } \\
\text { crystalline cherty } \\
\text { dolomite with }\end{array}$ & & \multirow{7}{*}{ Ozark Aquifer } & \\
\hline & $\begin{array}{l}\text { Jefferson City } \\
\text { Dolomite }\end{array}$ & 200 (Avg) & $\begin{array}{l}\text { green shale } \\
\text { laminations and } \\
\text { some thin } \\
\text { sandstone beds }\end{array}$ & 5 to $15 \mathrm{gpm}$ & & Mammoth Spring \\
\hline & $\begin{array}{l}\text { Roubidoux } \\
\text { Formation }\end{array}$ & 170 (Avg) & $\begin{array}{c}\text { Cherty, sandy } \\
\text { dolomite and } \\
\text { dolomitic } \\
\text { sandstone; oolitic }\end{array}$ & $\begin{array}{c}15 \text { to } 35 \mathrm{gpm} \\
\text { where shallow, } 50 \\
\text { to } 75 \text { where } \\
\text { deeply buried }\end{array}$ & & \multirow{4}{*}{$\begin{array}{c}\text { Hodgson Mill } \\
\text { Spring Greer Spring }\end{array}$} \\
\hline & Upper Gasconade & 40 (Avg) & $\begin{array}{l}\text { Massively- } \\
\text { bedded, coarse- } \\
\text { crystaline chert- } \\
\text { free dolomite }\end{array}$ & \multirow{2}{*}{$\begin{array}{l}\text { yields } 50 \text { to } 75 \\
\text { gpm }\end{array}$} & & \\
\hline & $\begin{array}{l}\text { Lower Gasconade } \\
\text { Dolomite }\end{array}$ & 250 (Avg) & $\begin{array}{c}\text { Very cherty } \\
\text { doloimte, } \\
\text { stramatolitic reef } \\
\text { zones in upper } \\
\text { part }\end{array}$ & & & \\
\hline & Gunter Sandtone & 25-30 (Avg) & Sandstone & $\begin{array}{l}40 \text { to } 50 \text { gpm- } \\
\text { normal yield, } 200 \\
\text { to } 500 \text { gpm } \\
\text { locally }\end{array}$ & & \\
\hline Cambrian & $\begin{array}{l}\text { Eminence } \\
\text { Dolomite }\end{array}$ & 220 (Avg) & $\begin{array}{l}\text { Medium to coarse } \\
\text { grained doloimte } \\
\text { with low chert } \\
\text { content. }\end{array}$ & $\begin{array}{l}\text { Yields from } 75 \text { to } \\
250 \mathrm{gpm}\end{array}$ & & Big Spring \\
\hline
\end{tabular}




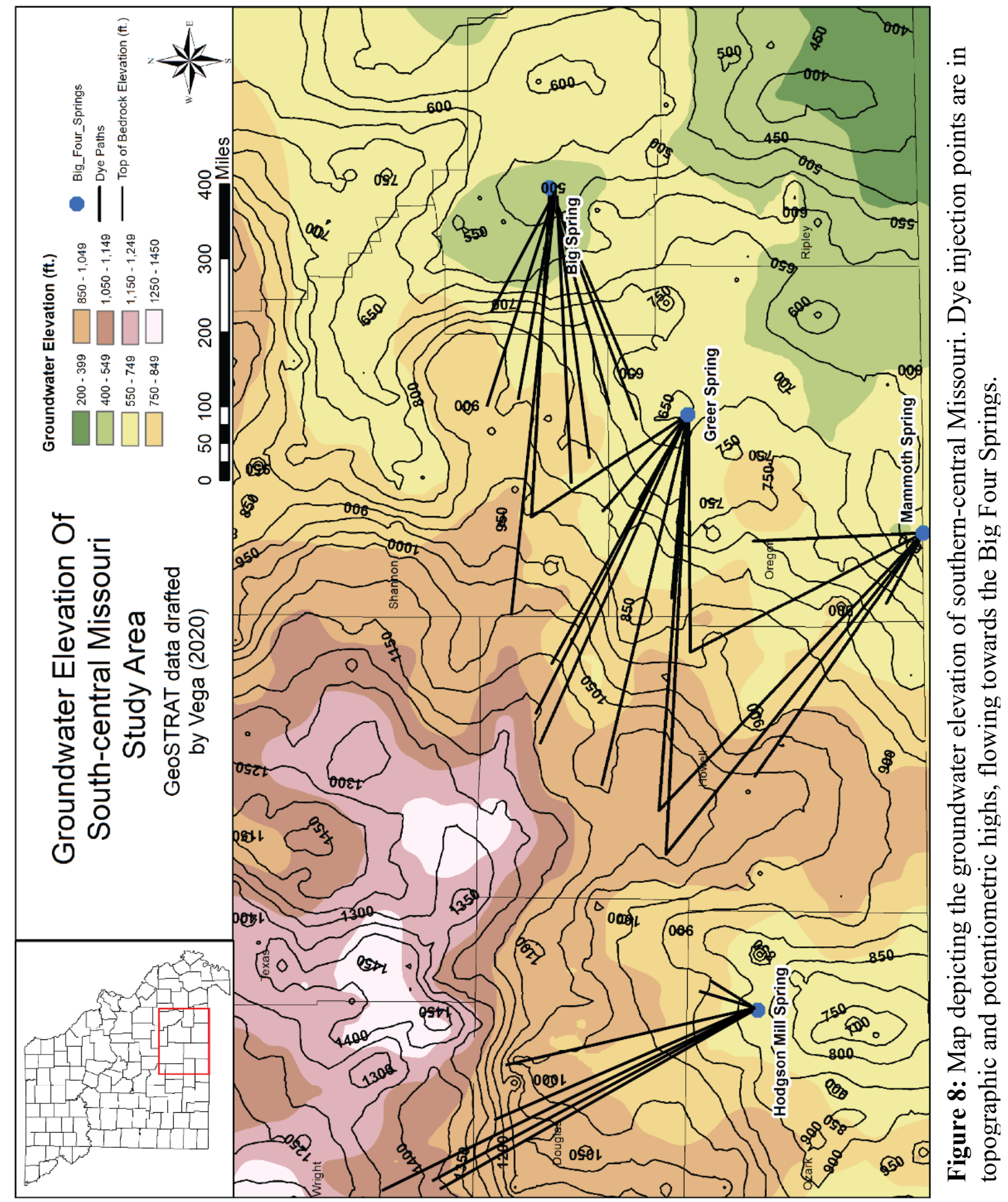




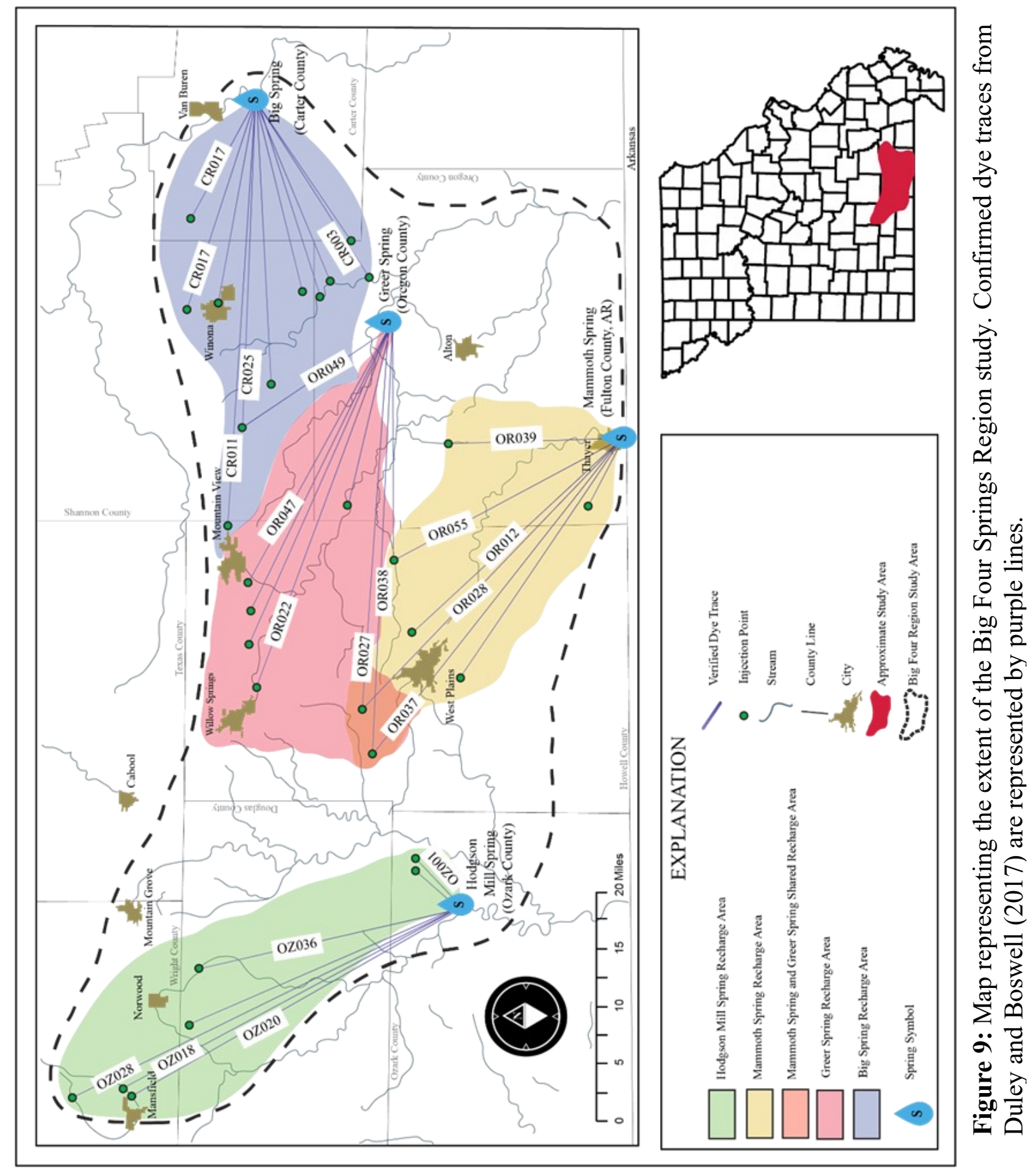




\section{Laboratory Analysis}

Laboratory analyses measured sulfate $\left(\mathrm{SO}_{4}^{-}\right)$, chloride $\left(\mathrm{Cl}^{-}\right), \mathrm{N}$ as $\mathrm{NO}_{2}{ }^{-}+\mathrm{NO}_{3}^{-}$, total recoverable metals, and total dissolved metals following standard methods (U.S. EPA., 2015; Baird and others, 2017). Metals that were evaluated using Inductively Coupled Plasma-Atomic Emission Spectroscopy (ICP-AES) were: calcium $\left(\mathrm{Ca}^{2+}\right)$, magnesium $\left(\mathrm{Mg}^{2+}\right)$, barium $\left(\mathrm{Ba}^{2+}\right)$, sodium $\left(\mathrm{Na}^{+}\right)$, potassium $\left(\mathrm{K}^{+}\right)$, iron $\left(\mathrm{Fe}^{3+}\right)$, boron $\left(\mathrm{B}^{3+}\right)$, titanium $\left(\mathrm{Ti}^{4+}\right)$, strontium $\left(\mathrm{Sr}^{2+}\right)$, and vanadium $\left(\mathrm{V}^{5+}\right)$. Trace elements analyzed using Inductively Coupled Plasmas Mass Spectroscopy (ICP-MS) were lead $\left(\mathrm{Pb}^{2+}\right)$, manganese $\left(\mathrm{Mn}^{2+}\right)$, and zinc $\left(\mathrm{Zn}^{2+}\right)$. The geochemical results of total dissolved metals for each sample from each spring are in Appendix A.

\section{Data Analysis}

Geochemical Modeling. Laboratory results and field measurements were evaluated using PHREEQC (Parkhurst and Appelo, 2013). This geochemical software follows an iterative approach to solve nonlinear algebraic equations such as chemical reactions, charge balance, and mass balance equations (Bethke, 1996; Thyne, 2007). The minteq.v4 master database was used to evaluate the spring waters, as it is an EPA-approved database specializing in metals (Thyne, 2007). PHREEQC provided descriptions of the charge balance error (CBE) of each sample.

$$
\text { Charge balance error }=\frac{(\text { cations }-\mid \text { anions } \mid)}{(\text { cations }+\mid \text { anions } \mid)} \times 100
$$

The CBE can be positive or negative, which indicates weather the waters had higher concentrations of cations $(+)$ or anions $(-)$. The CBE is reflective of ion bias and error from the results of the geochemical analysis. 
PHREEQC was used to determine the degree of saturation of aqueous mineral species using the equation below:

$$
\text { Saturation Index }(\mathrm{SI})=\frac{\text { IAP (ion activity product) }}{\text { Ksp (solubilityproduct) }}
$$

Where the ion activity product (IAP) is actual measured activities in a real solution and the solubility product $(\mathrm{Ksp})$ is the equilibrium constant for a solid substance dissolving in an aqueous solution (Thyne, 2007). The saturation index is reported in units of log SI where SI $=0$ is saturated, $\mathrm{SI}>0$ is super-saturated, and $\mathrm{SI}<0$ is under-saturated. Calcite and dolomite saturation of spring water at each site was evaluated using two different models.

Water classification was determined using GW_Chart (USGS, 2018) and plotting $\mathrm{Ca}^{2+}$, $\mathrm{Mg}^{2+}, \mathrm{Na}^{+}, \mathrm{K}^{+}$, alkalinity, $\mathrm{Cl}^{-}$, and $\mathrm{SO}_{4}{ }^{2-}$ into a piper diagram. The Big Four Springs water type was compared with other significant springs throughout the Ozarks in Missouri.

Statistical Modeling. IBM SPSS was used to screen the geochemical data to ensure they comply with assumptions encountered with linear discriminant analyses. The classification model in this project uses equal sample sizes with no missing data and as a result ignores the test for homogeneity of variance-covariance. Tests for outliers, normality, and multicollinearity were ran before the linear discriminant analysis in the classification model.

The factor analysis technique in was used through SPSS Version 24 to modify model one and use less predictor variables (dependent variables). The factor analysis further evaluates the predictor variables used in the linear discriminant analysis and identifies factors which reflect correlations among variables (Tabachnick and Fidell, 2013). This technique is useful in determining factors (a combination of geochemical variables) that provide the highest percentage of variance with the least number of independent variables. The Kaiser-Meyer-Olkin (KMO) 
Measure of Sampling Adequacy and the Bartlett's Test of Sphericity were initial tests to determine whether the factor analysis could be used (IBM SPSS, 2020).

The DISCRIM procedure utilized in SAS 9.4 was used to create a linear discriminant analysis model (LDA) to reduce dimensionality among dependent variables of groups, increasing group separability (Tharwat and others, 2017) and predict group membership. The LDA model establishes a criterion assuming linear relationships among all dependent variables associated with each independent variable (spring location). The dependent variables in this case are $\mathrm{pH}$, temperature, conductivity, alkalinity, $\mathrm{Ca}^{2+}, \mathrm{Mg}^{2+}, \mathrm{N}$ as $\mathrm{NO}_{2}{ }^{-}+\mathrm{NO}_{3}{ }^{-}, \mathrm{SO}_{4}{ }^{2-}, \mathrm{Na}^{+}$, and $\mathrm{Cl}^{-}$.

Of the geochemical variables measured in this project, only ten were used for the statistical analysis. The chosen dependent variables (DV) were $\mathrm{pH}$, temperature, conductivity, alkalinity, $\mathrm{Ca}^{2+}, \mathrm{Mg}^{2+}, \mathrm{N}$ as $\mathrm{NO}_{2}^{-}+\mathrm{NO}_{3}^{-}, \mathrm{SO}_{4}{ }^{2-}, \mathrm{Na}^{+}$, and $\mathrm{Cl}^{-}$. Model one used all ten variables to test the original model used by Lockwood (2018). Model two used a refined version of model one that best fits the Big Four Spring data. The dependent variables used in model two were $\mathrm{pH}$, $\mathrm{N}$ as $\mathrm{NO}_{2}{ }^{-}+\mathrm{NO}_{3}{ }^{-}, \mathrm{Mg}^{2+}$, and $\mathrm{Na}^{+}$.

The DISCRIM procedure was calibrated using $80 \%$ of the water samples (32 samples) from the Big Four Springs before testing the classification criterion. The remaining $20 \%$ of the water samples (8 samples) from the Big Four Springs were used as blind samples to test the classification criterion. The blind samples were chosen at random using the Microsoft Excel "Randbetween" function to generate random sample ID numbers. The percent classified output table determined the accuracy and robustness of the classification (Lockwood, 2018).

The DISCRIM procedure computes the probability of $\mathrm{x}$ belonging to group $\mathrm{t}$ by applying the Bayes' theorem: 


$$
p(t \mid x)=\frac{q_{t} f_{t}(x)}{f(x)}
$$

(SAS Institute Inc., 2018)

Where $\mathrm{q}_{\mathrm{t}}$ is the prior probability of membership in group $\mathrm{t}, \mathrm{f}_{\mathrm{t}}(\mathrm{x})$ is the group specific density estimate at $\mathrm{x}$ from group $\mathrm{t}$ and $\mathrm{f}(\mathrm{x})$ is the estimated unconditional density at $\mathrm{x}$ (SAS Institute Inc., 2018). The DISCRIM procedure develops a classification criterion (discriminant function) using a measure of generalized squared distances (SAS Institute Inc., 2018). The DISCRIM procedure uses the squared Mahalanobis distance equation. The classification criterion is based on withingroup covariance matrices and considers the prior probabilities of each group. The dependent variables are placed into the classes with the smallest generalized squared distance. The squared Mahalanobis distance equation is:

$$
\mathrm{d}_{\mathrm{t}}^{2}(\mathrm{x})=\left(\mathrm{x}-m_{t}\right)^{\prime} \mathrm{V}_{\mathrm{t}}^{-1}\left(\mathrm{x}-\mathrm{m}_{\mathrm{t}}\right)
$$

(SAS Institute Inc., 2018)

Where $\mathrm{V}_{\mathrm{t}}=$ the covariance matrix within group $\mathrm{t}\left(\mathrm{S}_{\mathrm{t}}\right)$ and $\mathrm{m}_{\mathrm{t}}$ is the $\mathrm{p}$-dimensional vector containing variable means in group $\mathrm{t}$. The group-specified density estimate at $\mathrm{x}$ from group $\mathrm{t}$ is given by the equation:

$$
f_{t}(x)=(2 \pi)^{-\frac{p}{2}}\left|V_{t}\right|^{-\frac{1}{2}} \exp \left(-0.5 d_{t}^{2}(x)\right)
$$

(SAS Institute Inc., 2018)

The posterior probability of $\mathrm{x}$ belonging to a group $\mathrm{t}$ is defined using Bayes' theorem:

$$
\mathrm{p}(\mathrm{t} \mid \mathrm{x})=\frac{\mathrm{q}_{\mathrm{t}} \mathrm{f}_{\mathrm{t}}(\mathrm{x})}{\Sigma_{u} q_{u} f_{u}(\mathrm{x})}
$$

(SAS Institute Inc., 2018) 
Where the summation is over all of the groups $u$. The generalized squared distance from $\mathrm{x}$ to group $t$ is defined as:

$$
\mathrm{D}_{\mathrm{t}}^{2}(\mathrm{x})=\mathrm{d}_{\mathrm{t}}^{2}(\mathrm{x})+g_{1}(\mathrm{t})+g_{2}(t)
$$

(SAS Institute Inc., 2018)

Where $g_{1}(t)=\ln \left|S_{t}\right|$ since the within-group covariance matrices are used and $g_{2}=-2 \ln \left(\mathrm{q}_{\mathrm{t}}\right)$ if the prior probabilities are not all equal or $\mathrm{g}_{2}=0$ if the prior probabilities are all equal.

The posterior probability of $\mathrm{x}$ belonging to group $\mathrm{t}$ is equal to:

$$
p(t \mid x)=\frac{\exp \left(-0.5 D_{t}^{2}(x)\right)}{\Sigma_{u} \exp \left(-0.5 D_{t}^{2}(x)\right)}
$$

(SAS Institute Inc., 2018)

Where $-0.5 D_{t}^{2}(x)$ are the discriminant scores. Mean discriminant scores are the mean centroids of the groups that determine how far groups are from each other. 


\section{RESULTS}

\section{Chemistry Data}

Table 3 summarizes the results from the Missouri Department of Natural Resources water analysis. The concentration data from each of the Big Four Springs were compared to the U.S. EPA (2018) drinking water standards. The Maximum Contaminant Level (MCL), Secondary Drinking Water Regulations (SDWR), and the Drinking Water Advisory standard limits were compared to the mean, median, minimum, and maximum concentrations of the results to better understand the water quality. The descriptive statistics of each constituent were also compared with the State of Missouri Safe Drinking Water Commission standard limits (State of Missouri, 2020). A full list of geochemical concentrations from each water sample at each spring site is in the appendices section of this report (Appendix A).

\section{Geochemical Evaluation}

Calcite And Dolomite Saturation Indices. All the Big Four Springs plotted below the saturation limits. Saturation index values for calcite ranged from -0.89 to -0.31 for Big Spring, 1.02 to -0.43 for Greer Spring, -0.63 to -0.29 for Mammoth Spring, and -0.66 to -0.18 for Hodgson Mill Spring (Table 4). Dolomite saturation appears to reflect similar trends as calcite, increasing over the sampling period and remaining undersaturated. Dolomite saturation indices ranged from -1.75 to -0.6 for Big Spring, -2.07 to -0.85 for Greer Spring, -1.24 to -0.56 for Mammoth Spring, and -1.33 to -0.36 for Hodgson Mill Spring (Table 5). 
Table 3. Descriptive statistics comparing Big Four Spring chemistry.

\begin{tabular}{|c|c|c|c|c|c|c|c|c|c|c|}
\hline Sampling locations & $\begin{array}{c}\text { Temp. } \\
\left({ }^{\circ} \mathrm{C}\right)\end{array}$ & $\mathbf{p H}$ & $\begin{array}{l}\text { Cond. } \\
\text { (uS/cm) }\end{array}$ & $\begin{array}{c}\text { Alk. } \\
\text { (CaCO3, } \\
\text { mg/L) }\end{array}$ & $\underset{(\mathrm{mg} / \mathrm{L})}{\mathrm{Ca}}$ & $\underset{(\mathrm{mg} / \mathrm{L})}{\mathrm{Mg}}$ & $\begin{array}{c}\mathrm{Cl} \\
(\mathrm{mg} / \mathrm{L})\end{array}$ & $\begin{array}{c}\text { Nitrogen } \\
(\mathrm{mg} / \mathrm{L})\end{array}$ & $\begin{array}{l}\text { Sulfate } \\
(\mathrm{mg} / \mathrm{L})\end{array}$ & $\begin{array}{c}\mathrm{Na} \\
(\mathrm{mg} / \mathrm{L})\end{array}$ \\
\hline \multicolumn{11}{|c|}{ Big Spring (10 samples) } \\
\hline Mean & 16.9 & 7.3 & 345 & 135 & 37.9 & 22.2 & 1.51 & 0.57 & 3.43 & 1.53 \\
\hline Median & 16.5 & 7.31 & 358 & 110 & 39 & 23 & 1.57 & 0.6 & 3.7 & 1.47 \\
\hline Min & 14.3 & 7.06 & 259 & 76 & 30.6 & 17.5 & 0.75 & 0.44 & 1.75 & 1.36 \\
\hline $\operatorname{Max}$ & 19.8 & 7.38 & 400 & 241 & 40.9 & 23.7 & 2.67 & 0.63 & 6.16 & 1.81 \\
\hline \multicolumn{11}{|c|}{ Greer Spring (10 samples) } \\
\hline Mean & 15.7 & 7.2 & 333 & 116 & 36.5 & 21.5 & 2.32 & 1.14 & 3.51 & 1.66 \\
\hline Median & 15.75 & 7.25 & 345 & 122 & 38.3 & 23 & 2.53 & 1.16 & 4.07 & 1.66 \\
\hline Min & 13.8 & 7.05 & 260 & 62 & 28.7 & 17.5 & 0.75 & 1.02 & 1.75 & 1.46 \\
\hline Max & 16.6 & 7.4 & 374 & 171 & 40.1 & 23.7 & 3.75 & 1.23 & 5.8 & 1.86 \\
\hline \multicolumn{11}{|c|}{ Mammoth Spring (10 samples) } \\
\hline Mean & 18.94 & 7.17 & 429 & 190 & 47.92 & 27.79 & 3.88 & 1.4 & 5.32 & 2.19 \\
\hline Median & 19.35 & 7.18 & 435 & 185 & 48.1 & 28.3 & 3.82 & 1.38 & 5.31 & 2.1 \\
\hline Min & 14.5 & 6.98 & 389 & 148 & 44.4 & 24.8 & 3.03 & 1.1 & 3.85 & 1.76 \\
\hline Max & 21.4 & 7.38 & 470 & 244 & 51.7 & 29.4 & 4.83 & 1.64 & 7.06 & 2.73 \\
\hline \multicolumn{11}{|c|}{ Hodgson Mill Spring (10 samples) } \\
\hline Mean & 17.48 & 7.23 & 399 & 189 & 43.48 & 24.94 & 5.19 & 1.65 & 5.67 & 2.27 \\
\hline Median & 18.15 & 7.27 & 407 & 192 & 44.55 & 26 & 5.04 & 1.7 & 5.52 & 2.3 \\
\hline Min & 13.6 & 7.07 & 340 & 137 & 37 & 21 & 4.58 & 0.62 & 4.29 & 2.1 \\
\hline Max & 19.7 & 7.33 & 444 & 251 & 48.4 & 26.6 & 6.67 & 2.09 & 7.77 & 2.46 \\
\hline EPA Standards & - & $6.5-8.5$ & - & - & - & - & 250 & 10 & 500 & 20 \\
\hline \multicolumn{11}{|c|}{ Missouri Water Quality } \\
\hline Standards & - & $6.5-8.5$ & - & - & - & - & 250 & 10 & 250 & - \\
\hline
\end{tabular}


Table 3 continued. Descriptive statistics comparing Big Four Spring chemistry.

\begin{tabular}{|c|c|c|c|c|c|c|c|c|c|c|c|}
\hline Sampling locations & $\begin{array}{c}\mathrm{K} \\
(\mathrm{mg} / \mathrm{L})\end{array}$ & $\begin{array}{c}\mathbf{B a} \\
(\mathbf{u g} / \mathbf{L})\end{array}$ & $\underset{(\mathrm{ug} / \mathrm{L})}{\mathrm{Cu}}$ & $\begin{array}{c}\mathrm{Fe} \\
(\mathrm{ug} / \mathrm{L})\end{array}$ & $\begin{array}{c}\mathrm{Pb} \\
(\mathrm{ug} / \mathrm{L})\end{array}$ & $\begin{array}{c}\text { Mn } \\
\text { (ug/L) }\end{array}$ & $\begin{array}{c}\mathbf{N i} \\
(\mathrm{ug} / \mathrm{L})\end{array}$ & $\begin{array}{c}\text { Sn } \\
(\mathbf{u g} / \mathbf{L})\end{array}$ & $\begin{array}{c}\mathbf{T i} \\
(\mathrm{ug} / \mathrm{L})\end{array}$ & $\begin{array}{c}\mathrm{Zn} \\
(\mathbf{u g} / \mathrm{L})\end{array}$ & $\begin{array}{c}\text { V } \\
(\mathrm{ug} / \mathrm{L})\end{array}$ \\
\hline \multicolumn{12}{|l|}{ Big Spring (10 samples) } \\
\hline Mean & 0.55 & 30.5 & 0.77 & 2.7 & $<0.50$ & $<0.50$ & 1.25 & 2.27 & 9.77 & 2.64 & $<1$ \\
\hline Median & 0.68 & 30.7 & $<0.50$ & $<0.50$ & $<0.50$ & $<0.50$ & 1.1 & 0.99 & 9.14 & 1.75 & $<1$ \\
\hline Min & $<0.1$ & 28.1 & $<0.50$ & $<0.50$ & $<0.50$ & $<0.50$ & 0.25 & $<0.5$ & $<0.5$ & 1.16 & $<1$ \\
\hline Max & 1.29 & 31.9 & 2.85 & 14.8 & $<0.50$ & 0.95 & 2.88 & 10.7 & 17.6 & 7.95 & 1.67 \\
\hline \multicolumn{12}{|l|}{ Greer Spring (10 samples) } \\
\hline Mean & 1.1 & 38.7 & $<0.5$ & 5.7 & $<0.50$ & 0.5 & 1.2 & 1.3 & 9.23 & 2.66 & $<1$ \\
\hline Median & 1.3 & 36.7 & $<0.5$ & $<0.5$ & $<0.50$ & $<0.50$ & 0.95 & $<0.50$ & 8.52 & 2.12 & $<1$ \\
\hline Min & 0.39 & 33.7 & $<0.5$ & $<0.5$ & $<0.50$ & $<0.50$ & $<0.50$ & $<0.50$ & $<0.50$ & 0.88 & $<1$ \\
\hline Max & 1.71 & 64.6 & 1.49 & 20.2 & $<0.50$ & $<0.50$ & 2.36 & 8.58 & 17.2 & 5.68 & 2.56 \\
\hline \multicolumn{12}{|l|}{ Mammoth Spring (10 samples) } \\
\hline Mean & 1.5 & 39 & 0.64 & 6.11 & $<0.50$ & 1.21 & 1.52 & 3.9 & 12.08 & 4.75 & $<1$ \\
\hline Median & 1.63 & 36.3 & $<0.5$ & 1.05 & $<0.50$ & 1.11 & 1.45 & 3.85 & 12.15 & 2.68 & $<1$ \\
\hline Min & 0.78 & 32.7 & $<0.50$ & $<1$ & $<0.50$ & 0.66 & $<0.5$ & 1.27 & $<0.5$ & 2.18 & $<1$ \\
\hline Max & 2.24 & 68.8 & 2.69 & 41.5 & $<0.50$ & 1.85 & 3.2 & 6.3 & 22.5 & 17.8 & 1.54 \\
\hline \multicolumn{12}{|l|}{ Hodgson Mill Spring (10 samples) } \\
\hline Mean & 1.49 & 40.5 & $<0.50$ & 3.76 & $<0.50$ & $<0.50$ & 1.32 & 1.33 & 11.19 & 3.1 & 1 \\
\hline Median & 1.48 & 41.1 & $<0.50$ & $<1$ & $<0.50$ & $<0.50$ & 1.1 & $<0.50$ & 9.89 & 3.02 & $<1$ \\
\hline Min & 0.63 & 37 & $<0.50$ & $<1$ & $<0.50$ & $<0.50$ & $<0.50$ & $<0.50$ & $<0.50$ & 2.4 & $<1$ \\
\hline Max & 2.24 & 41.9 & 0.63 & 16.7 & $<0.50$ & 0.78 & 2.82 & 8.58 & 19.6 & 4.33 & 2.67 \\
\hline EPA Standards & - & 2000 & 1300 & 300 & 15 & 50 & - & - & - & 500 & - \\
\hline Missouri Water Quality Standards & - & 2000 & 1300 & 300 & 15 & 50 & - & - & - & 500 & - \\
\hline
\end{tabular}


Table 4: Calcite saturation summary statistics

\begin{tabular}{cccccc}
\hline \hline Springs & Mean & Median & Min & Max & SD \\
\hline Big Spring & -0.57 & -0.59 & -0.89 & -0.31 & 0.19 \\
Greer Spring & -0.71 & -0.70 & -1.02 & -0.43 & 0.21 \\
Mammoth Spring & -0.40 & -0.39 & -0.63 & -0.29 & 0.10 \\
Hodgson Mill Spring & -0.41 & -0.4 & -0.66 & -0.18 & 0.16 \\
\hline
\end{tabular}

Table 5: Dolomite saturation summary statistics

\begin{tabular}{cccccc}
\hline Springs & Mean & Median & Min & Max & SD \\
\hline Big Spring & -1.12 & -1.18 & -1.75 & -0.6 & 0.37 \\
Greer Spring & -1.42 & -1.26 & -2.07 & -0.85 & 0.44 \\
Mammoth Spring & -0.77 & -0.75 & -1.24 & -0.56 & 0.19 \\
Hodgson Mill Spring & -0.83 & -0.84 & -1.33 & -0.36 & 0.31 \\
\hline
\end{tabular}

\section{Statistical Modeling}

Data Screening. A Normal Predicted Probability (P-P) plot (Figure 10) was used to test for normality. Outliers in the data set were examined by comparing Mahalanobis Distances to chi-square distributions with ten degrees of freedom which are the number of variables used in model one. No multivariate outliers were detected in the statistical dataset where P-values for all variables used in the statistical model is $>0.001$ (Appendix B) (Tabachnick and Fidell, 2013). The assumption test for homogeneity was ignored since this model utilizes equal sample sizes for each group. The SAS 9.4 DISCRIM procedure protects against multicollinearity checking for tolerance thus, no formal evaluation is necessary (Tabachnick and Fidell, 2013).

Model One. Results from the calibration cross-validation procedure of model one predicted that $100 \%$ of the calibration water samples from Big Spring, Greer Spring, and 96\% of the samples from Mammoth Spring would be classified correctly and the probability of error is 
low. Hodgson Mill Spring has more error than the other Big Four Springs, with approximately $75 \%$ of the spring water samples correctly classified. On all three runs of model one, approximately $25 \%$ of the calibration samples from Hodgson Mill Spring were likely to be Mammoth Spring water samples. Samples 24 and 25 from the Hodgson Mill Spring calibration samples have a $99 \%$ and $98 \%$ posterior probability of being classified as Mammoth Spring samples, respectively. Mammoth Spring, sample 40, has a 99\% posterior probability of being misclassified as a Greer Spring sample, indicating that the sample closely resembles water samples similar to Greer Spring. Results regarding the unknown sample classification of model one showed that $100 \%$ of the unknown samples were classified correctly to their spring even with error present in the model.

Factor Analysis. The KMO statistic is near 1.0, at a value of 0.705 indicating that the factor analysis is useful with the chemical data. Values less than 0.50 indicates that factor analysis is likely not very useful with the data provided (IBM SPSS, 2020). The Bartlett's test is less than 0.05 (significance level), at 0.000 indicating that the factor analysis is useful with the data corresponding with the KMO statistic (Table 6). The communalities in Table 7A described the proportion of variance accounted for in each variable small values in the extraction column indicate that variables do not fit well with the factor solution and should likely be dropped from the analysis (IBM SPSS, 2020). An extraction value less than 0.650 was used to reduce the predictor variables. The extraction limit method suggested that conductivity, nitrogen, $\mathrm{Cl}^{-}, \mathrm{Ca}^{2+}$, $\mathrm{Mg}^{2+}$, and $\mathrm{Na}^{+}$are suitable to use in the following classification model. The components in Table 7B corresponds with the variables in the extraction table showing relatively high correlation values in component one than component two. 
Model Two. Results from the calibration cross-validation of model two indicate changes in probability classification for Mammoth Spring and Hodgson Mill Spring. Classification error for Hodgson Mill Spring was reduced from 25\% to $12.50 \%$ of misclassification potential. In contrast, Mammoth Spring exhibits an increase in error from $4 \%$ to approximately $22 \%$. Mammoth Spring, sample 33, has an approximate $74 \%$ posterior probability that it will be classified as a Hodgson Mill Spring sample. Sample 40 from Mammoth Spring has a 60\% posterior probability of being misclassified as a Greer Spring sample, a $<1 \%$ probability of being classified as a Hodgson Mill Spring sample, and approximately $39 \%$ chance of being classified as a Mammoth Spring sample. Results regarding the unknown sample classification of model two revealed that an unknown Mammoth Spring sample was misclassified as a Hodgson Mill Spring sample. Model two exhibited a decrease in classification accuracy when classifying unknowns compared to model one.

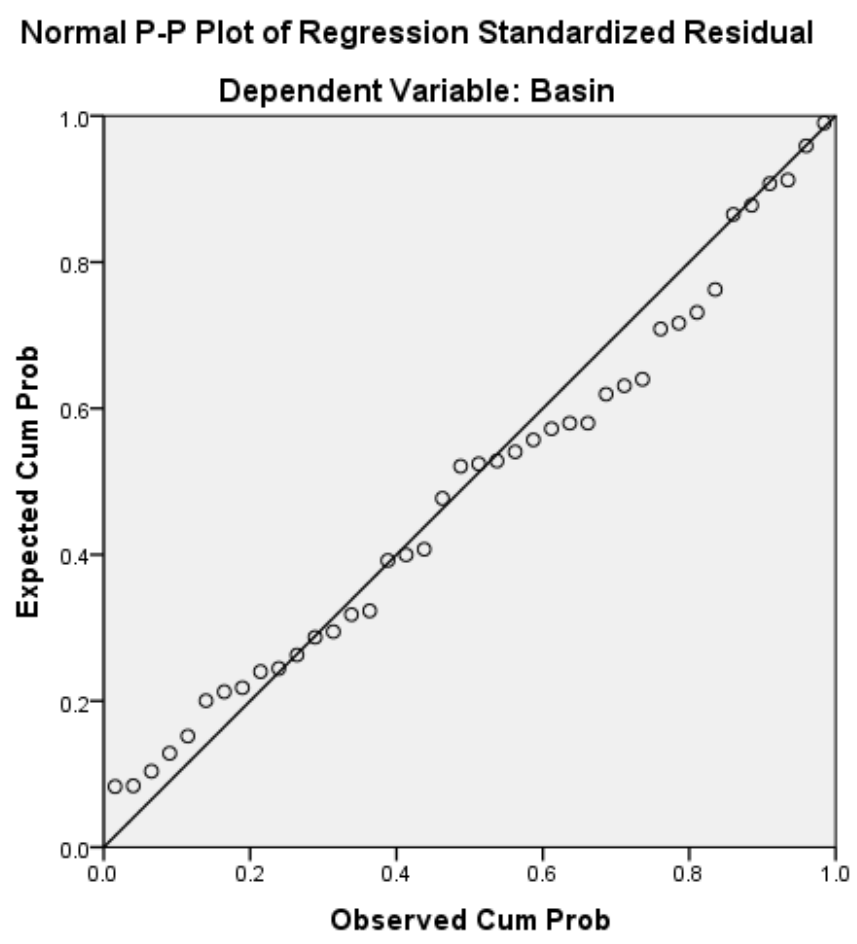

Figure 10: Normal P-P plot depicting normality of water samples in the classification model. 
Table 6: KMO and Bartlett's Test suggesting factor analysis is useful with the chemistry data KMO and Bartlett's Test

\begin{tabular}{llr}
\hline Kaiser-Meyer-Olkin measure of sampling adequacy: & 0.7 \\
Bartlett's Test of Sphericity: & Approx. Chi-Square & 460.05 \\
& df & 45 \\
& Sig. & 0
\end{tabular}

Table 7: Communalities (A) and components (B) results used to determine which variables to drop and which to keep for model two.

\begin{tabular}{|c|c|c|c|c|c|}
\hline \multicolumn{3}{|c|}{ A. Communalities } & \multicolumn{3}{|c|}{ B. Components } \\
\hline & Initial & Extraction & & One & Two \\
\hline pH & 1 & 0.6 & pH & 0.14 & -0.76 \\
\hline temp & 1 & 0.48 & temp & 0.06 & 0.69 \\
\hline conduct & 1 & 0.95 & conduct & 0.97 & 0 \\
\hline alk & 1 & 0.59 & alk & 0.74 & 0.2 \\
\hline $\mathrm{Cl}$ & 1 & 0.73 & Cl & 0.65 & 0.55 \\
\hline SO4 & 1 & 0.62 & SO4 & 0.13 & 0.77 \\
\hline nitrogen & 1 & 0.75 & nitrogen & 0.48 & 0.72 \\
\hline $\mathbf{C a}$ & 1 & 0.91 & $\mathbf{C a}$ & 0.94 & 0.12 \\
\hline Mg & 1 & 0.88 & Mg & 0.94 & 0.05 \\
\hline $\mathbf{N a}$ & 1 & 0.88 & $\mathbf{N a}$ & 0.56 & 0.75 \\
\hline
\end{tabular}

Extraction Method: Principal Component

Analysis. 


\section{DISCUSSION}

\section{Water Quality}

All the inorganic components in this project are below the Missouri Drinking Water Standards that reflect the 2018 U.S EPA Primary Drinking Water Standards and the U.S EPA Secondary Drinking Water Regulations (Table 3) (State of Missouri, 2020; U.S. EPA, 2018). Contaminants of major concerns such as arsenic, antimony, mercury, beryllium, boron, cadmium, chromium, cobalt, molybdenum, selenium, silver and thallium that were analyzed in this study are below the detection limit of the analysis and do not exceed the safe drinking water limits (State of Missouri, 2020; U.S. EPA, 2018). These data indicate that the waters collected at each spring site are safe to use under natural conditions. Caution must be taken when these waters are used, since the springs are located in mature karst terrains that will allow contaminants to quickly flow through the subsurface and into the aquifer. Use of water at the spring sites is currently not allowed for human consumption or development. Sampling activities were conducted following permits provided with special guidelines. The conductivities of these springs are well within the freshwater and drinking water ranges, which are between 300 to 800 $\mathrm{uS} / \mathrm{cm}$ and drinking water 50 to $500 \mathrm{uS} / \mathrm{cm}$ respectively (Rusydi, 2018).

\section{Chemical Analysis}

Nitrogen ( $\mathbf{N}$ as $\left.\mathbf{N O}_{2}^{-}+\mathbf{N O}_{3}{ }^{-}\right)$. Nitrate was found to be less than the U.S. EPA maximum contaminant level (MCL) and the Missouri Water Quality Standards MCL of $10 \mathrm{mg} / \mathrm{L}$ (U.S. EPA., 2018; State of Missouri, 2020;. The highest concentrations of nitrogen are found in Hodgson Mill Spring compared to the rest of the spring sites, ranging between 1.47 to 2.09 
$\mathrm{mg} / \mathrm{L}$. Mammoth Spring had nitrogen levels between 1.1 to $1.64 \mathrm{mg} / \mathrm{L}$. Greer Spring had a lesser range compared to Mammoth Spring, with nitrogen concentrations ranging between 1.02 to 1.23 $\mathrm{mg} / \mathrm{L}$. Big Spring had the lowest range in nitrogen concentration, between 0.44 to $0.63 \mathrm{mg} / \mathrm{L}$. Excessive nitrate in the water may cause restrictions in oxygen transport in the blood and is more hazardous to infants which may cause blue baby syndrome. Concentrations at all four study sites are considered to be natural background levels and are not hazardous to human health (DeSimone and others, 2009). Nitrogen levels in the Big Four Springs corresponds with National Water-Quality Assessment Program (NWQAP) studies that were performed on domestic wells in the Ozarks in Missouri. The NWQAP results measured groundwater from the Ozark aquifer and determined that nitrogen concentrations were greater than $1 \mathrm{mg} / \mathrm{L}$ but less than the U.S EPA health limit of $10 \mathrm{mg} / \mathrm{L}$ (DeSimone and others, 2009). Nitrogen variations can be seen in Figure 11 during the sampling period at each spring site.

Temperature And Conductivity. Greer Spring's water is the coldest out of the four springs with water temperature ranging between 13.8 to $16.6^{\circ} \mathrm{C}$. It is also less conductive with conductivity ranging between 260 to $374 \mathrm{uS} / \mathrm{cm}$. Big Spring had similar temperature to Mammoth Spring and Hodgson Mill Spring, with a temperature ranging between 14.3 to 19.8 ${ }^{\circ} \mathrm{C}$. Hodgson Mill Spring is relatively cooler (between 13.6 to $19.7^{\circ} \mathrm{C}$ ) and less conductive $(340$ to $444 \mathrm{uS} / \mathrm{cm}$ ) than Mammoth Spring. Mammoth Spring tends to be the warmest waters of the four spring sites as well as the most conductive with temperature ranging between 14.5 to 21.4 ${ }^{\circ} \mathrm{C}$ and conductivity ranging between 389 to $470 \mathrm{uS} / \mathrm{cm}$. Conductivity variations can be observed in Figure 12. Conductivity is almost twice as high at Mammoth Spring and Hodgson Mill Spring compared to Greer Spring and Big Spring suggesting that the groundwater is in contact with the aquifer rock longer than Mammoth Spring and Hodgson Mill Spring. 
Alkalinity. Bicarbonate is the dominant species of alkalinity considering that all spring locations in the Big Four Region were near neutral ( $\mathrm{pH}$ of 7). Alkalinity titration revealed that Mammoth Spring and Hodgson Mill Spring have similar alkalinity measurements which ranged between 148 to $244 \mathrm{mg} / \mathrm{L}$ and 137 to $251 \mathrm{mg} / \mathrm{L}$ respectively. Big Spring had alkalinity measurements ranging between 76 to $241 \mathrm{mg} / \mathrm{L}$ and Greer Spring with alkalinity measurements ranging between 62 to $171 \mathrm{mg} / \mathrm{L}$. Big Spring and Greer Spring alkalinity measurements were typically less than Mammoth Spring and Hodgson Mill Spring. Differences from each spring are likely linked to residence times within the aquifer. The data suggests that the water from Mammoth Spring and Hodgson Mill Spring likely spends more time with the aquifer rock dissolving more dolomite aquifer rock compared to Big Spring and Greer Spring.

Magnesium/Calcium Ratio $\left(\mathrm{Mg}^{2+} / \mathrm{Ca}^{2+}\right)$. The $\mathrm{Mg}^{2+} / \mathrm{Ca}^{2+}$ ratio is an indicator of the lithological composition of the aquifer matrix (Razowska-Jaworek, 2014). The $\mathrm{Mg}^{2+} / \mathrm{Ca}^{2+}$ ratios of all four spring are near 1:1, reflecting dolomite dissolution. The Big Four Springs have nearly similar $\mathrm{Mg}^{2+} / \mathrm{Ca}^{2+}$ ratios ranging from 0.95 to 0.97 . The calculated $\mathrm{Mg}^{2+} / \mathrm{Ca}^{2+}$ ratios compared with the geology of the Big Four Springs confirms that the groundwater interacts mostly with the dolomite formations of the Ozark aquifer. In comparison, Springfield Plateau springs have average $\mathrm{Mg}^{2+} / \mathrm{Ca}^{2+}$ ratios between 0.05 to 0.07 which is indicative of limestone dissolution of the aquifer rock (Razowska-Jaworek, 2014). The Big Four Springs waters are considered to have very hard water and may form deposits on substrates (i.e. glassware, hands, hair, water heaters and laundry) when the water is heated and evaporated (DeSimone and others, 2009). These waters are not dangerous at these levels but are unsightly and may cause damage in pipes and appliances. 
Redox Reactions. The redox state of the groundwater samples collected at all four sites were classified as oxic. This was determined based on $\mathrm{N}$ as $\mathrm{NO}_{2}{ }^{-}+\mathrm{NO}_{3}{ }^{-}, \mathrm{Mn}^{2+}, \mathrm{Fe}^{3+}, \mathrm{SO}_{4}{ }^{2-}$ and historical dissolved oxygen data from the national Water Quality Monitoring Council. Dissolved oxygen data spans from 1990 until 2019. Concentrations of $\mathrm{Mn}^{2+}$ and $\mathrm{Fe}^{3+}$ at all sites were less than $50 \mathrm{ug} / \mathrm{L}$ and $100 \mathrm{ug} / \mathrm{L}$ limits established by Jurgens and others (2009) (Table 3). All spring sites had $\mathrm{SO}_{4}{ }^{2-}$ concentrations that were less than the $250 \mathrm{mg} / \mathrm{L}$ MCL per the Missouri Water Quality Standards (Table 3) and historical mean oxygen levels above $7 \mathrm{mg} / \mathrm{L}$ (Big Spring: 8.5 mg/L, Greer Spring: 9.3 mg/L, Mammoth Spring: 7.2 mg/L, and Hodgson Mill Spring: 8.3 mg/L). (McMahon and Chapelle, 2007).

Mammoth Spring Hydrology. Sappa and others (2014) reported high concentrations of total dissolved solids, conductivity, magnesium, and calcium ions indicated longer groundwater residence times. The most recent dye tracing study in the Big Four Springs Region by Duley and Boswell (2017) reveals dye paths to the Big Four Springs have similar average lengths. This data coupled with Sappa and others (2014) and Hays and others (2016) geochemical residence time indicators can provide insight into relative groundwater interaction and relative flow velocity at each spring site. The relatively high ionic concentrations found in Mammoth Spring and Hodgson Mill Spring, compared to Big Spring and Greer Spring, are linked to the geologic formations of the Big Four Springs. Groundwater flow to Mammoth Spring begins at the lesspermeable middle-Ozark aquifer consisting of the Cotter/Jefferson City Dolomite before moving through the more permeable Roubidoux Formation which was confirmed through dye traces in a previous study (Imes and Emmett, 1994; Hays and others, 2016). Previous dye tracing studies completed by Duley and Boswell (2017) revealed that recharge and groundwater flows through the Roubidoux Formation toward Mammoth Spring (Figure 9). Waters flowing through the 
Cotter/Jefferson City Dolomite and Roubidoux Formation before surfacing at Mammoth Spring are likely reacting with the host rock for longer time compared to rest of the spring sites.

Hodgson Mill Spring Hydrology. Hodgson Mill Spring likely has similar hydrology to Mammoth Spring, although recharge waters flow through the Cotter/ Jefferson City and into the Roubidoux Formation before flowing and surfacing in the upper-Gasconade Dolomite at Hodgson Mill Spring. Hodgson Mill Spring typically has relatively lower ionic concentrations compared to Mammoth Spring. This is likely due to recharge flowing into Hodgson Mill Spring occurring quickly compared to recharge at Mammoth Spring. Dye tracing studies performed by Duley and Boswell (2017) indicated that dye could be detected approximately one week earlier at Hodgson Mill Spring opposed to Mammoth Spring at similar dye path distances.

Big Spring Hydrology. The lower ionic concentrations at Big Spring are also linked to residence times. Recharge typically flows through the Cotter/Jefferson City Dolomite, into the Roubidoux Formation, and the Gasconade Dolomite before surfacing in the Eminence Dolomite at Big Spring. Although recharge water enters the water table through the less permeable Cotter/Jefferson City Dolomite, the area in which recharge occurs for Big Spring has higher cave densities than Mammoth Spring and Hodgson Mill Spring. The Gasconade Dolomite and the Eminence Dolomite are known to be highly permeable water bearing strata with large caves existing within them (Imes and Emmett, 1994; Lowell and others, 2010).

Greer Spring Hydrology. Ionic concentrations at Greer Spring tend to be similar to Big Spring. This is due to similar flow paths through higher cave density and permeable region of the recharge area for Greer Spring. Recharge occurs similarly to Big Spring. Recharge waters move through the cave dense section of the Cotter/Jefferson City Dolomite in the Greer Spring 
recharge area. Water rapidly continues to flow into the Roubidoux Formation before surfacing at the lower-Gasconade Dolomite.

\section{Groundwater Classification}

Water samples collected from the Big Four Springs are classified as calcium-magnesiumbicarbonate water type. This is consistent with other springs located in the Salem Plateau and is what would be expected of water from the Ozark Aquifer discharging from dolomite formations. Springs from the Springfield, Missouri area are located on Mississippian limestone, known as the Burlington-Keokuk Formation. These springs were plotted on the Piper Diagram to compare water type with those of the Big Four Springs (Figure 13). A clear deviation can be seen from the limestone aquifer matrix of the Springfield aquifer of the Springfield Plateau compared to the dolomite aquifer matrix of the Ozark aquifer of the Salem Plateau. These springs plot

predominantly as calcium-bicarbonate water type, which is expected from waters discharging from limestone formations.

Calcite Saturation. Calcite saturation index provides insight to whether water will deposit calcite or maintain it in solution. Calcite saturation data suggests that groundwater emerging from Mammoth Spring and Hodgson Mill Spring likely spend more time reacting with the aquifer rock than the waters at Big Spring and Greer Spring. Figure 14A shows in calcite saturations indices at each spring location. The longer that the waters are in contact with the aquifer rock and use up dissolved $\mathrm{CO}_{2}$ the more saturated the groundwater becomes with respect to calcite (Shuster and White, 1971). Since the waters are all undersaturated with respect to calcite, the calcite saturation index suggests that the groundwaters are corrosive enough to continue to dissolve the aquifer rock. Some factors that may explain these signatures are the 
relative distances that groundwater must move through from each springs' recharge area. Dye tracing data indicates that some dye paths ranged from 20 to 40 miles at each spring site and provided times that dye detection peaked. Dye peaks were usually detected within one to two weeks at Big Spring and Greer Spring and two to three weeks at Hodgson Mill Spring and Mammoth Spring (Duley and Boswell, 2017).

Dolomite Saturation. Dolomite saturation mirrors the calcium saturation at each site (Figure 14B). Mammoth Spring and Hodgson Mill Spring dolomite saturation is closer to the mean and less varied compared to Big Spring and Greer Spring. Big Spring and Greer Spring have relatively more variation. The differences are the result from the different lengths of time the groundwaters are in contact with the dolomite rocks (Shuster and White, 1971). The lesser time the groundwater was in contact with the aquifer rock at Big Spring and Greer Spring resulted in dolomite indices that were further away from equilibrium. Dolomite saturation indices from Mammoth Spring and Hodgson Mill Spring samples were twice as close to equilibrium than Big Spring and Greer Spring. As previously stated, dye tracing data also confirms the relative residence times of the groundwater that supplies each spring (Duley and Boswell, 2017).

\section{Statistical Analysis}

Model One. Model one classified 100\% of the unknown samples (8 of 8) from the Big Four Springs dataset. This indicates that if an unknown sample were to be collected from any of the Big Four Springs during the sampling period, there is a high probability that the unknown sample could be classified correctly to its respective basin. The increase in classification probability is likely due to the same number of samples collected at each spring at the Big Four 
Spring study area compared to a model with uneven number of samples. Different weights would be needed to adjust the robustness of springs with fewer samples or uneven sample set sizes. Although model one classified $100 \%$ of the unknown samples, cross-validation reveal that the model does contain error. Figure 15 illustrates the group centroids of the model one. The spring centroids reveals that there is overlap between Mammoth Spring and Hodgson and slight overlap between Big Spring and Greer Spring. This suggests that unknown samples may be misclassified in future projects. Figure 16 depicts the discriminant ability of model one by using the linear discriminant scores from each spring site.

Model Two. Model two classified 88\% (7 of 8 ) of the blind samples to their respective spring location. The distance to each centroid for Hodgson Mill Spring and Mammoth Spring are much closer compared to model one (Figure 17). Figure 18 demonstrates the overlap of the discriminant scores of the model two. This indicates that although fewer variables can be used to successfully develop a classification model, more error is expected. The classification model is significant at determining blind water samples with a relatively high degree of accuracy in comparison to the previous model (Lockwood, 2018). This is likely attributed with the previous issue regarding uneven sample sizes and missing data.

\section{General Discussion}

Purpose One. It was noticeable during the data collection period that Big Spring and Greer Spring were similar in chemistry as were Mammoth Spring and Hodgson Mill Spring. Temperature, $\mathrm{pH}$, conductivity, and alkalinity provided a preliminary field assessment in distinguishing the similarities and the differences of each group of the Big Four Springs. This study offers insight to potential contamination from human development. The chemical data in 
this study suggests that human development and agriculture do not negatively impact the water quality of the Big Four Springs. Instead, the concentrations depict natural background concentrations of the Ozark Aquifer in the Salem Plateau (Vineyard and Feder, 1974; Imes and Emmett, 1994).

Purpose Two. This study also determined that the water discharging from the Big Four Springs were not equilibrated with the aquifer rock. All the waters sampled from the Big Four Springs were undersaturated with respect to calcite and dolomite indicating that these waters are not precipitating calcite at the orifice of the springs and are corrosive enough to dissolve the aquifer rock. There was an overall increasing trend in calcite saturation and dolomite saturation as the sampling period moved closer to late summer/early fall.

This project was able to determine the water that issues from these four major springs is calcium-magnesium-bicarbonate water type. The water type discharging from the OrdovicianCambrian dolomites of the Salem Plateau are different than the water type discharging from the Springfield Plateau that discharges from the Springfield aquifer and out from Mississippian Limestones.

Purpose Three. This study refined models that identified unique signatures in spring water basins. The discriminant function analysis from SAS 9.4 was used to predict the membership probability of a randomly selected unknown (blind) to each of the Big Four Springs. Two models were developed and tested for accuracy and efficiency. The first in this study used all ten constituents $\left(\mathrm{pH}\right.$, temperature, conductivity, alkalinity, $\mathrm{Ca}^{2+}, \mathrm{Mg}^{2+}, \mathrm{N}$ as $\mathrm{NO}_{2}^{-}+\mathrm{NO}_{3}^{-}$, $\mathrm{SO}_{4}{ }^{2-}, \mathrm{Na}^{+}$, and $\mathrm{Cl}^{-}$) used by Lockwood (2018). The first model was $100 \%$ accurate classifying 8 out of 8 unknown samples even with a 100\% spring classification during calibration of the model. The second factor analysis ran by Lockwood (2018) identified that $\mathrm{pH}$, temperature, 
conductivity, alkalinity (bicarbonate), and chloride were the most significant variables in that study. However, since the Big Four Springs are in a different region it was decided to use factor analysis to establish principal predictor variables. The six variables identified were conductivity, nitrogen, $\mathrm{Cl}^{-}, \mathrm{Ca}^{2+}, \mathrm{Mg}^{2+}$, and $\mathrm{Na}^{+}$. Model two in this study revealed that six variables, if robust enough, can still be used to develop a membership probability model using linear discriminant analysis. Note that new models that are established to predict membership probability must be screened to determine principle components unique to each study. This is especially true when combining springs with different chemistries (i.e. the dolomite springs of the Big Four Springs and the limestone springs from Springfield, Missouri).

The statistical analyses support the findings from Duley and Boswell (2017), that the Big Four Springs have separate recharge areas. The chemical variables used in these analyses show that the Mohalonobis distance matrix (Appendix B) shows that the each of the spring sites have a level of significance that is $<0.0001$. This is less than alpha $(0.05)$ indicating that the chemical variables in each spring group are significantly different (IBM SPSS, 2020).

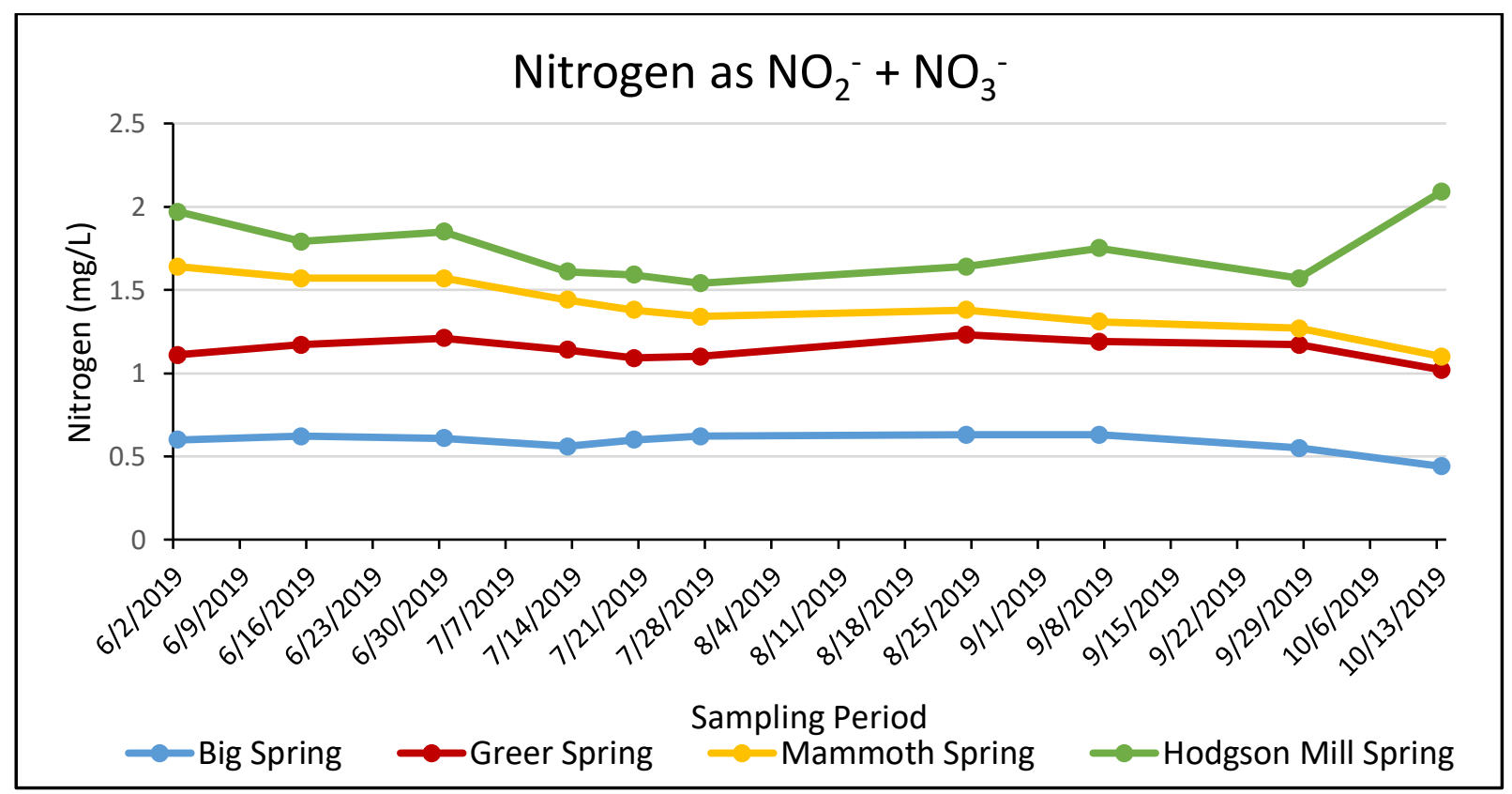

Figure 11: Nitrogen concentrations of the Big Four Springs during the sampling period. 


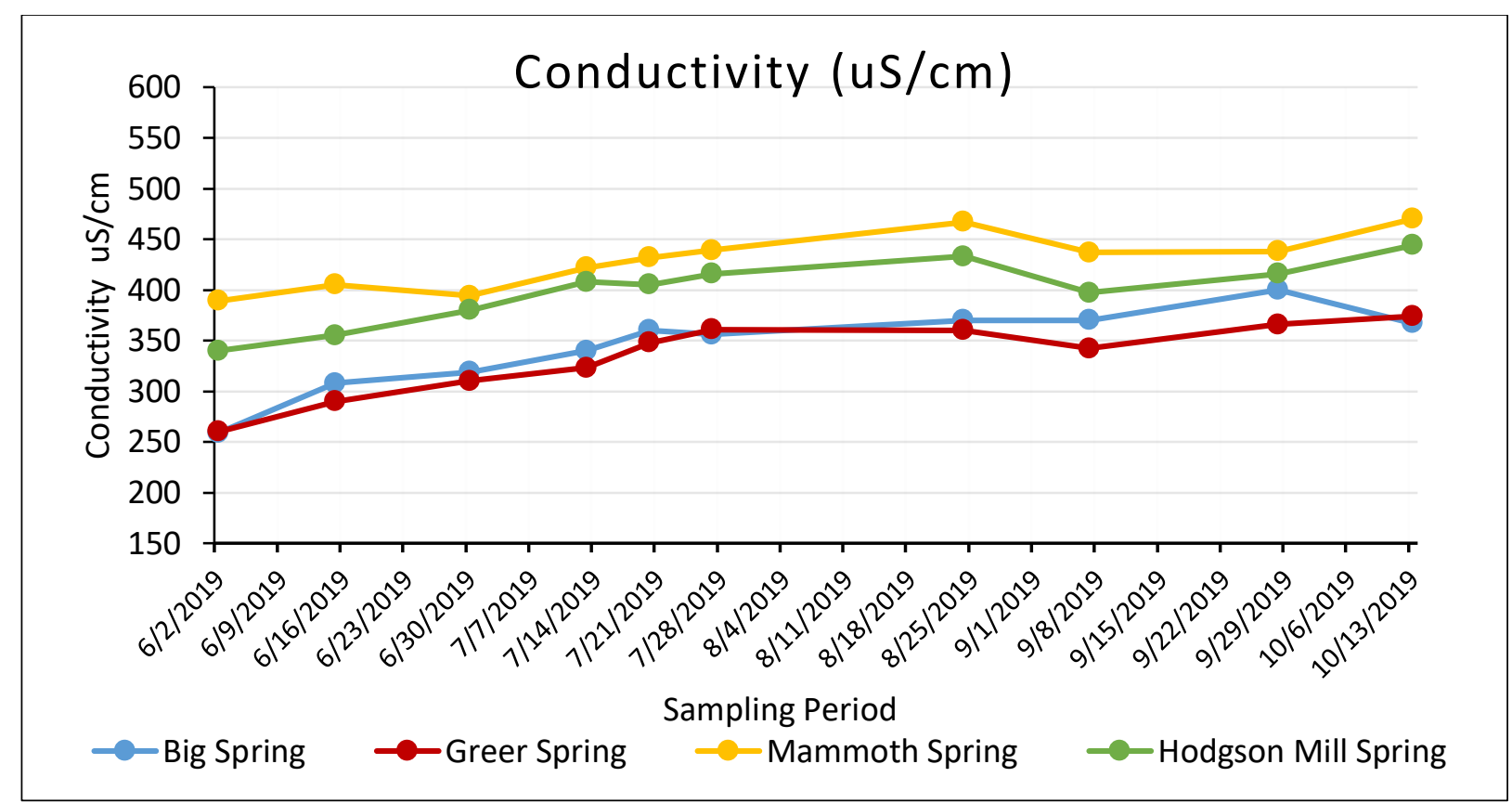

Figure 12: Conductivity variations of the water samples throughout the sampling period.

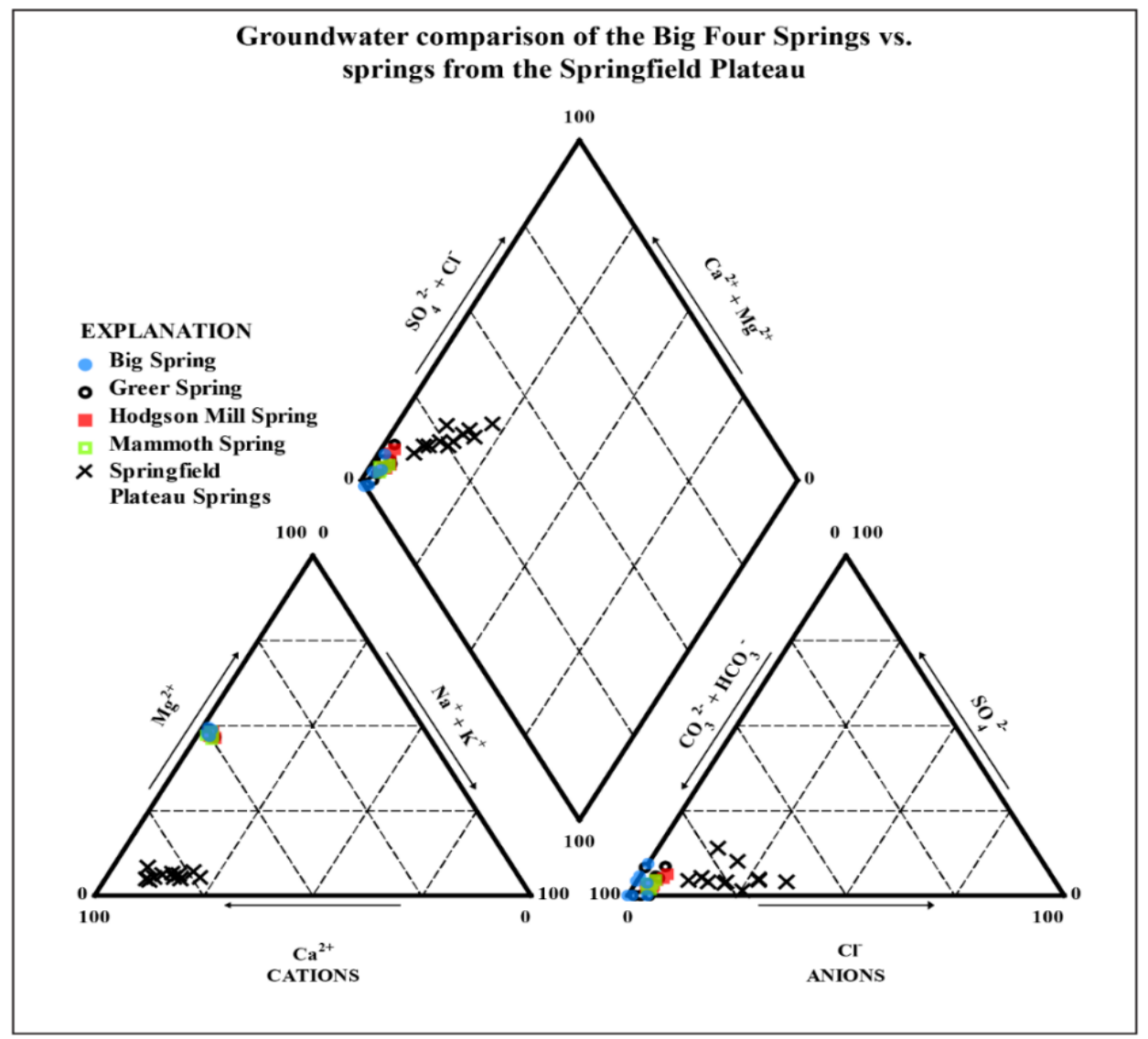

Figure 13: Piper diagram representing groundwater type of the Big Four Springs and Springs in located in Springfield, MO. Comparison data from Springfield, MO, is from Lockwood (2018). 


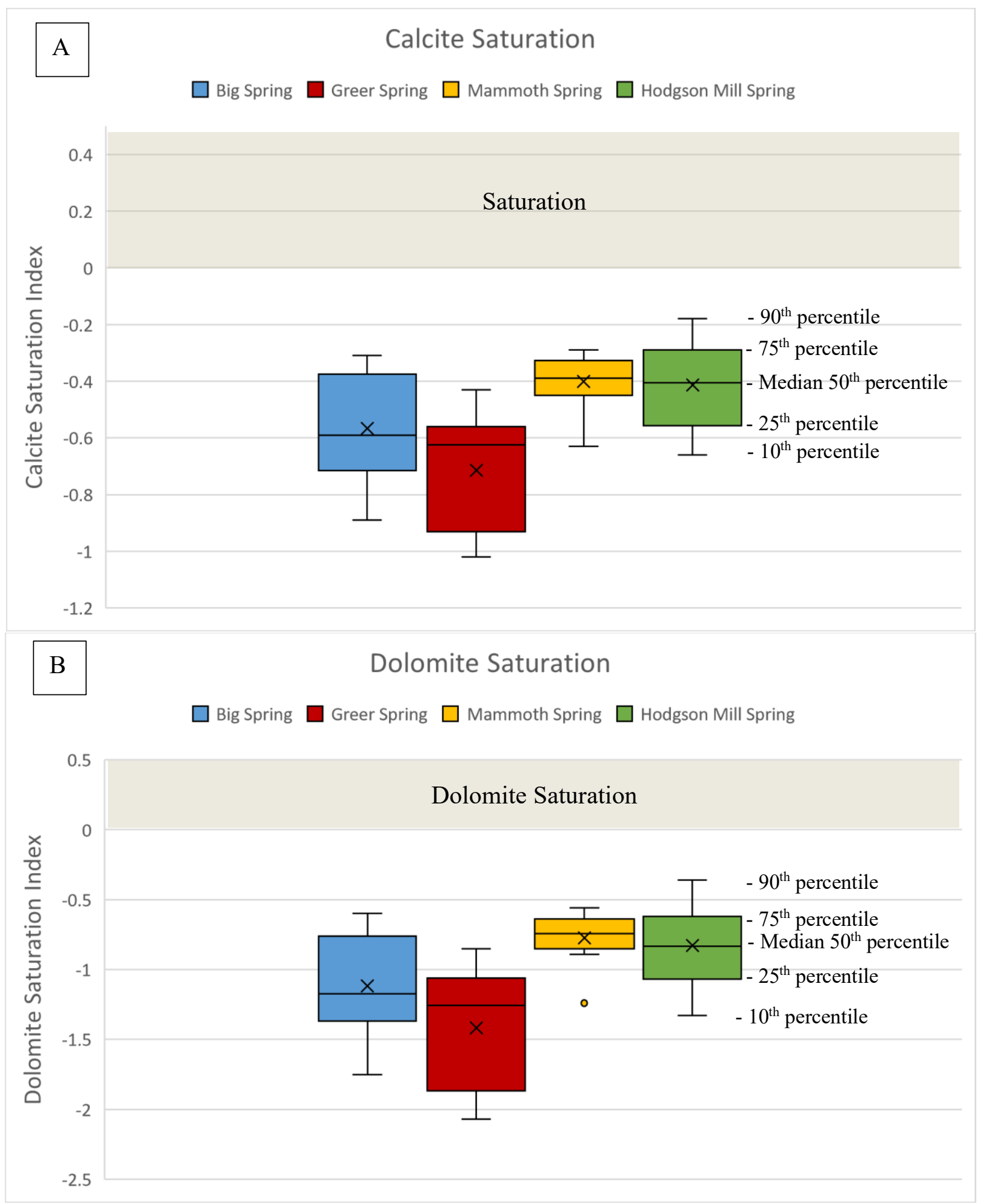

Figure 14: Box and Whisker graphs depicting the median, shape, and variation of calcite (A) and dolomite (B) saturation indices from each spring site. 


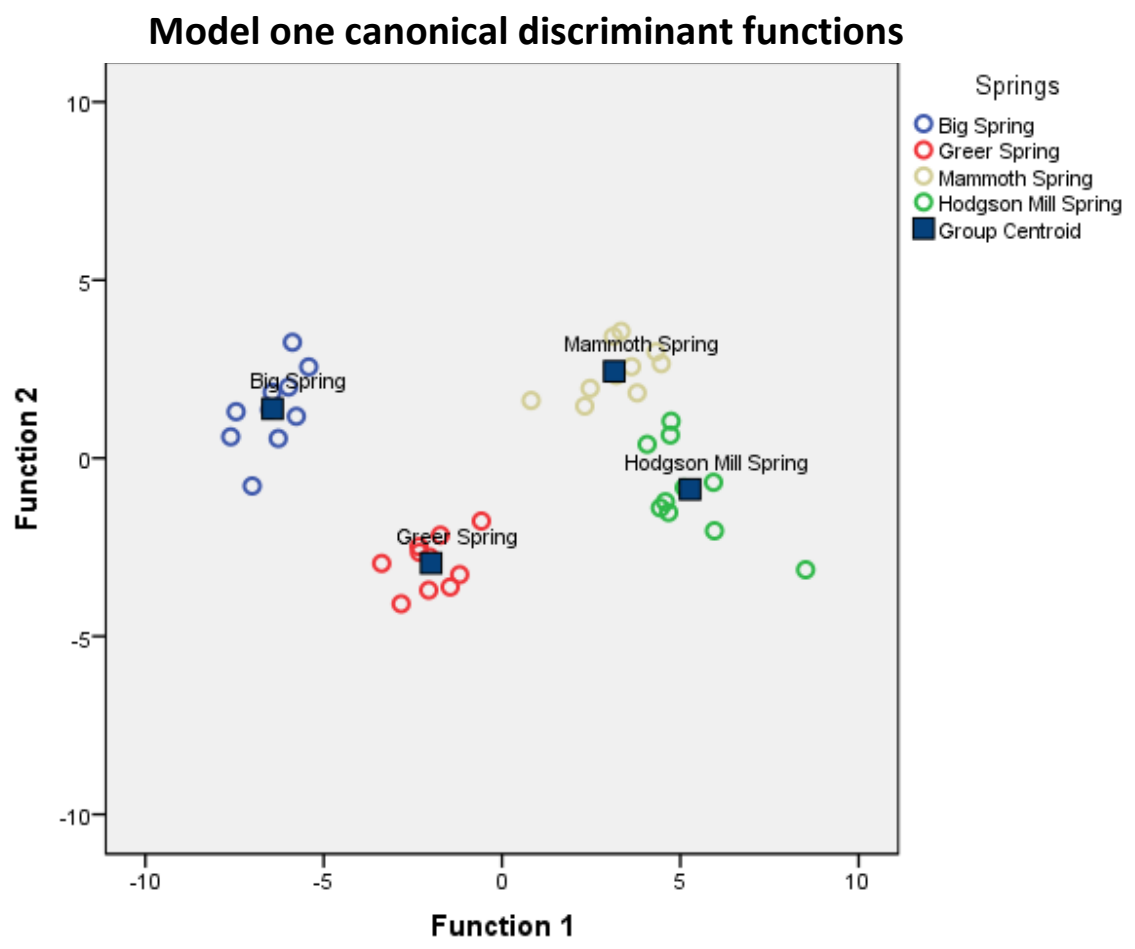

Figure 15: Graphically represents the discriminant ability of model one using all ten variables.

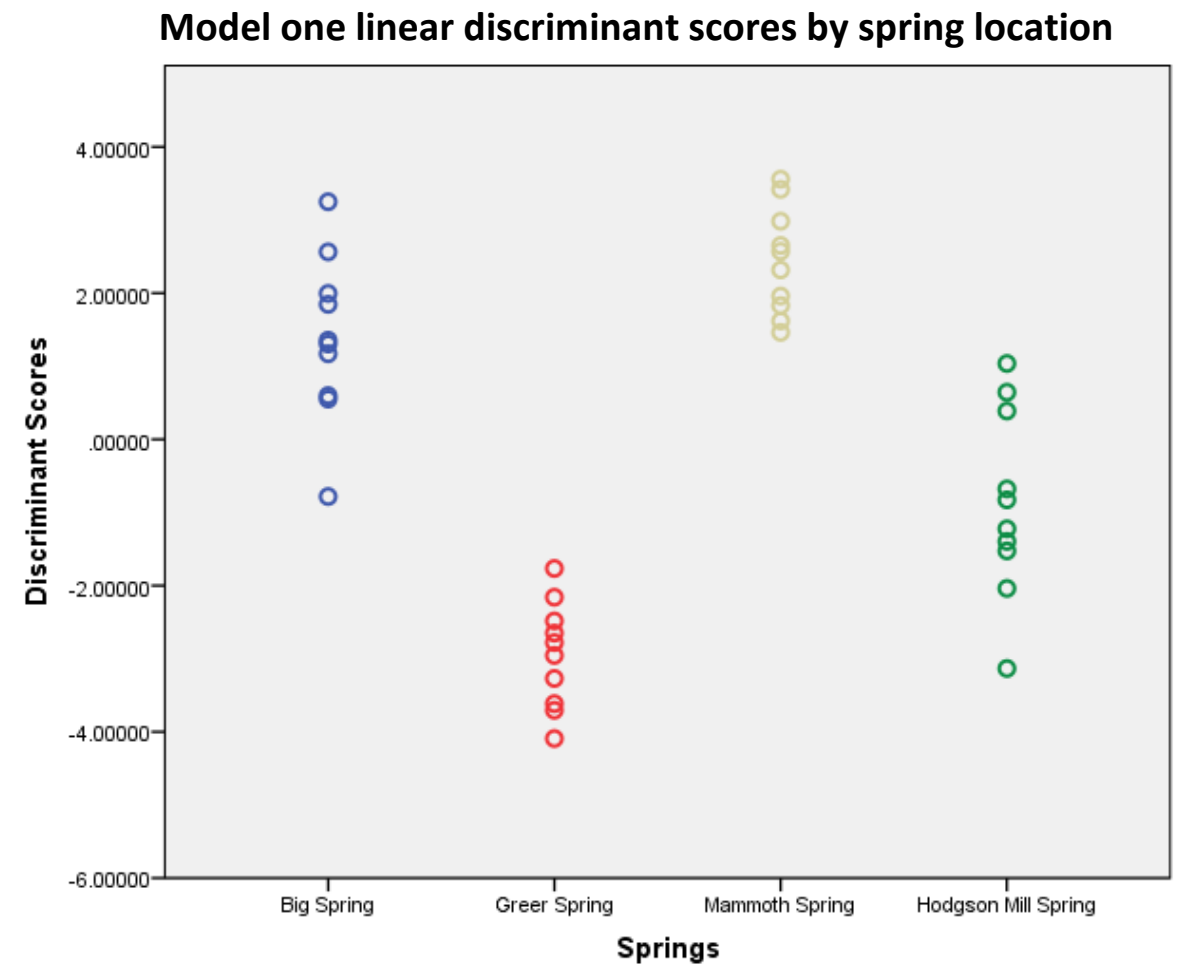

Figure 16: Linear discriminant scores from each spring site illustrating the discriminant ability of model one. 


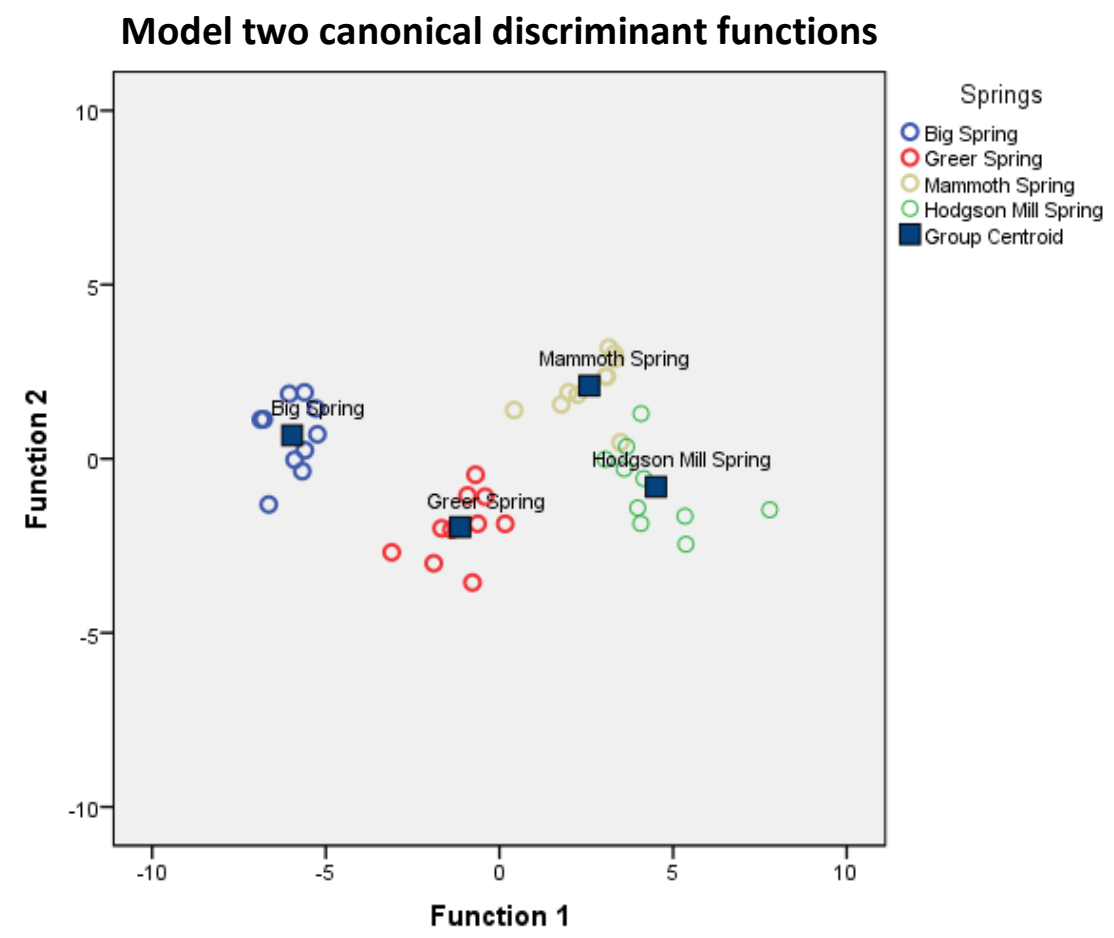

Figure 17: Graphically represents the discriminant ability of model two

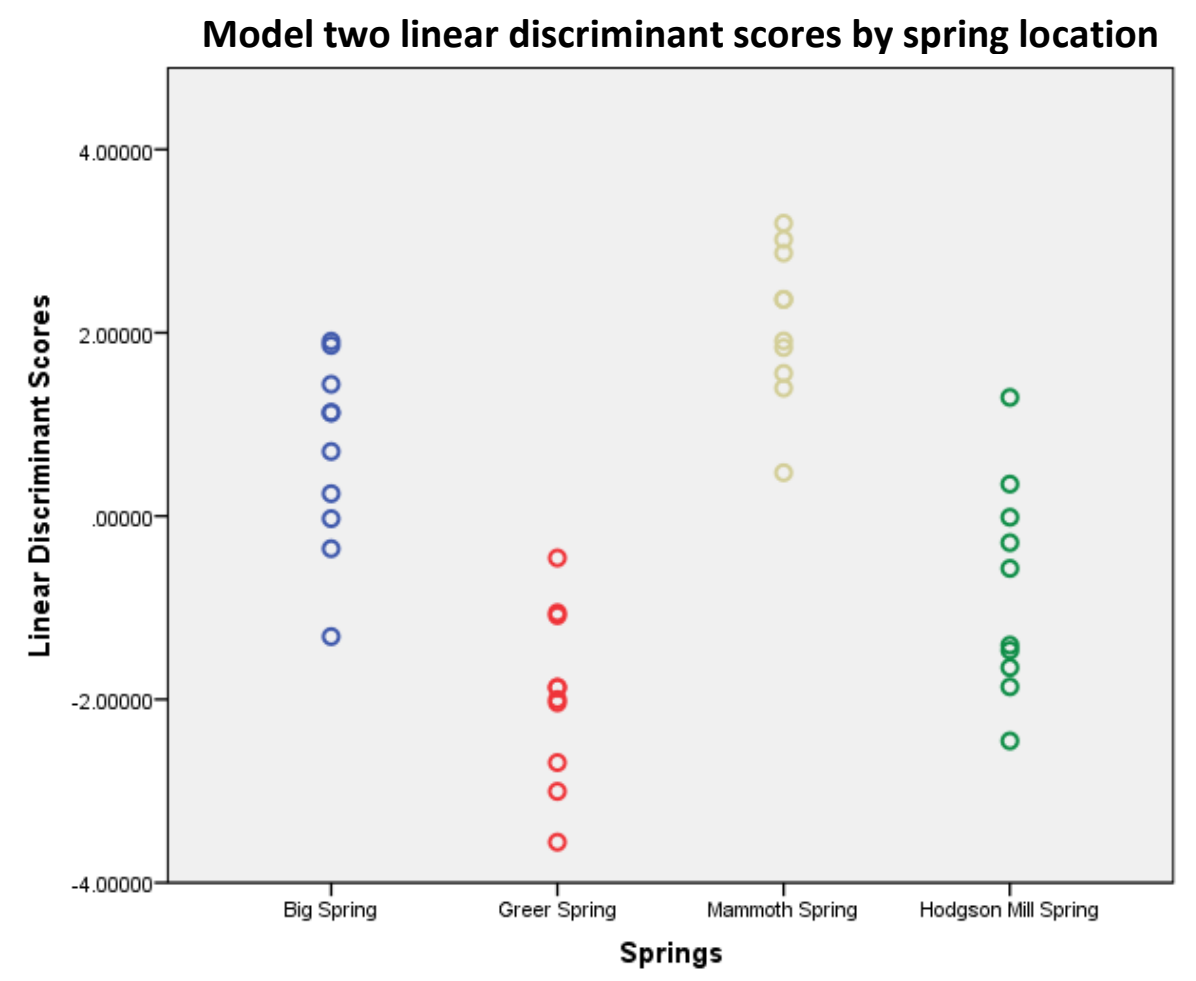

Figure 18: Discriminant ability of model two using only using conductivity, nitrogen, $\mathrm{Cl}^{-}, \mathrm{Ca}^{2+}$, $\mathrm{Mg}^{2+}$, and $\mathrm{Na}^{+}$as predictor variables. 


\section{CONCLUSION}

The baseline chemistry evaluated in this study shows that the chemical signatures are consistent with the Ozark aquifer chemistry found in the region (Vineyard and Feder, 1974; Imes and Emmett, 1994; Schumacher and Kleeschulte, 2010). The water sample data provided insights into the quality of the water being discharged from the four spring sites. In this case, waters discharging from each of the four spring sites are safe to use when comparing the inorganic concentration limits set forth by the Missouri Drinking Water Standards and the EPA Safe Drinking Water Standards. This information is helpful where many southern Missouri residents are already using groundwater from the region.

The degree of calcite and dolomite saturation were determined based on the water chemistry and using PHREEQC. The waters discharging from all four springs sites were undersaturated with respect to calcite and dolomite, indicating that the springs are not in equilibrium with the aquifer rock. The data suggests that the groundwater discharging from the Big Four Springs can dissolve the aquifer rock.

The $\mathrm{Mg}^{2+} / \mathrm{Ca}^{2+}$ ratios at each spring site are near one. There are minor differences in $\mathrm{Mg}^{2+} / \mathrm{Ca}^{2+}$ ratios between each spring site indicating that the groundwater recharge, which is mostly dedicated to each spring, occurs in dolomite rocks that are overall geochemically similar.

A linear discriminant analysis using SAS 9.4 was used to develop two classification models. The study confirmed that using ten samples from each spring site along with all ten variables $\left(\mathrm{pH}\right.$, temperature, conductivity, alkalinity, $\mathrm{Ca}^{2+}, \mathrm{Mg}^{2+}, \mathrm{N}^{2} \mathrm{NO}_{2}{ }^{-}+\mathrm{NO}_{3}{ }^{-}, \mathrm{SO}_{4}{ }^{2-}, \mathrm{Na}^{+}$, and $\mathrm{Cl}^{-}$) is robust enough to reveal that the water chemistries at each site are significantly different than one another. It also confirmed that $100 \%$ of the blind samples 8 of 8 were correctly 
identified. These findings support dye tracing and groundwater monitoring done by Duley and Boswell (2017), which indicated that although there may be overlapping dye traces, most of the groundwater that discharges at the Big Four Springs are from independent recharge areas dedicated to each spring site. A second discriminant analysis model (conductivity, nitrogen, $\mathrm{Cl}$, $\mathrm{Ca}^{2+}, \mathrm{Mg}^{2+}$, and $\mathrm{Na}^{+}$) used six of the ten variables which was also robust enough differentiate each spring site. The model was $88 \%$ ( 7 of 8 ) accurate in correctly identifying blind samples to their respective spring locations when dropping $40 \%$ of the predictor variables. 


\section{FUTURE WORK}

It is recommended that additional studies include testing for bacteria, viruses, and other organics before the groundwater in the region is to be used for drinking purposes. Statistical refinement is needed to increase the overall accuracy of the classification model. This requires more water samples from each site to establish a more robust classification of each spring or basin studied. It is recommended that each spring or spring basin should have the same number of samples to reduce overlap of linear discriminant scores. This may require collecting more samples at each site to better delineate each spring location. This could increase the accuracy of the model for sites with fewer samples if uneven samples were collected. 


\section{REFERENCES CITED}

Aley, T.J., 1972, Groundwater contamination from sinkhole dumps: The Journal of Caves and Karst, v. 14, p. 17-23.

Baird, R.B., Eaton, A.D., and Rice, E.W., 2017, APHA, Standard methods for the examination of water and wastewater, American Public Health Association: Washington, DC., American Public Health Association.

Bethke, C.M., 1996, Geochemical reaction modeling: concepts and applications: New York, Oxford University Press, Inc., 389 p.

DeSimone, L.A., Hamilton, P.A., and Gilliom, R.J., 2009, Quality of water from domestic wells in principal aquifers of the United States, 1991-2004 Overview of major findings: National Water-Quality Assessment Program, Cicular 1332, 1991-2004 p., doi:9781411323506

Doll, W.L., 1938, Hydrography of the larger springs of the Ozark region of Missouri: [Unpublished thesis], University of Missouri Rolla, 106 p.

Drever, J.I., 1982, The geochemistry of natural waters: Englewood Cliffs, Prentice-Hall, Inc., $385 \mathrm{p}$.

Duley, J.W., and Boswell, C., 2017, An update on the recharge areas of selected large springs in the Big Four Region of the Ozarks: Water Resources Report Number 76, p. 155.

Ford, F. and Williams, P., 2007, Karst hydrogeology and geomorphology, DOI:10.1002/9781118684986.

Gouzie, D.R., 1986, Carbonate geochemistry and chemical discrimination of ground water basins in portions of the Inner Bluegrass karst region, Kentucky [Ph.D. thesis]: Lexington, University of Kentucky.

Hanshaw, B.B., and Back, W., 1985, Deciphering hydrological systems by means of geochemical processes: Hydrological Sciences Journal, v. 30, p. 257-271, doi:10.1080/02626668509490988.

Hays, P.D., Knierim, K.J., Breaker, B., Westerman, D.A., and Clark, B.R., 2016, Hydrogeology and hydrologic conditions of the Ozark Plateaus aquifer system: U.S. Geological Survey Scientific Investigations Report, p. 61.

Hedden, W.J., 1968, The geology of the Thayer area emphasizing the stratigraphy of the Cotter and the Jefferson City formations [M.S. thesis]: University of Missouri-Rolla, $159 \mathrm{p}$.

Hem, J.D., 1985, Study and interpretation of the chemical characteristics of natural water, Washington, U.S. Department of the Interior, $253 \mathrm{p}$. 
IBM SPSS, $2020 \mathrm{KMO}$ and Bartlett's Test, https://www.ibm.com/support/knowledgecenter/SSLVMB_23.0.0/spss/tutorials/fac_telco_k mo_01.html (accessed April 2020).

Imes, J.L., and Emmett, L.F., 1994, Geohydrology of the Ozark Plateaus Aquifer system in parts of Missouri, Arkansas, Oklahoma, and Kansas: USGS Professional Paper 1414-D, p. 140.

Jeelani, G.H., Bhat, N.A., Shivanna, K., and Bhat, M.Y., 2011, Geochemical characterization of surface water and spring water in SE Kashmir valley, western Himalaya: Implications to water-rock interaction: Journal of Earth System Science, v. 120, p. 921-932, doi:10.1007/s12040-011-0107-0.

Jurgens, B.C., McMahon, P.B., Chapelle, F.H., and Eberts, S.M., 2009, An Excel workbook for identifying redox processes in groundwater: U.S. Geological Survey Open-File Report 2009-1004, p. 8.

Lockwood, B.E., 2018, Chemical and statistical analysis of karst groundwater basin signatures Springifeld, Mo [M.S. thesis]: Missouri State University, 88 p., https://bearworks.missouristate.edu/theseshttps://bearworks.missouristate.edu/theses/3254.

Lowell, G.R., Harrison, R.W., Weary, D.J., Orndorff, R.C., Repetski, J.E., and Pierce, H.A., 2010, Rift-related volcanism and karst geohydrology of the southern Ozark dome: v. 17, 99-158 p., doi:10.1130/2010.0017(06).

McMahon, P.B., and Chapelle, F.H., 2007, Redox processes and water quality of selected principal aquifer systems: Ground Water, v. 46, p. 259-271, doi:https://doi.org/10.1111/j.1745-6584.2007.00385.x.

Michalik, A., 2008, The use of chemical and cluster analysis for studying spring water quality in Wietokrzyski National Park: Polish Journal of Environmental Studies, v. 17, p. 357-362.

Missouri Geological Survey, 2019, Physiographic regions of Missouri: Department of Natural Resources Publication 2515, https://dnr.mo.gov/pubs/docs/pub2515.pdf

Mugel, D.N., Richards, J.M, and Schumacher, J.G., 2009, Geohydrology investigations and landscape characteristics of areas contriubuting water to springs, the Current River, and Jacks Fork, Ozark National Scenic Riverways, Missouri: USGS Scientific Investigations Report 2009-5138, 80 p.

Nabi, R., Karbassi, A.R., Mehrdadi, N., and Bidhendi, M.E., 2009, Evaluation of spatial and seasonal variations in surface water quality using multivariate statistical techniques: International Journal of Environmental Science \& Technology, v. 6, p. 467-476, doi:10.1007/BF03326086. 
Newell, D.L., Jessup, M.J., Cottle, J.M., Hilton, D.R., Sharp, Z.D., and Fischer, T.P., 2008, Aqueous and isotope geochemistry of mineral springs along the southern margin of the Tibetan plateau, Implications for fluid sources and regional degassing of $\mathrm{CO} 2$ :

Geochemistry, Geophysics, Geosystems: An Electronic Journal of the Earth Sciences, v. 9, p. 1-20, doi:10.1029/2008GC002021.

Parkhurst, D.L. and Appelo, C.A.J., 2013, Description of input and examples for PHREEQC version 3: a computer program for speciation, batch-reaction, one-dimensional transport, and inverse geochemical calculations: United States Geological Survey, Techniques and Methods Series 6-A43, doi: 10.3133/tm6A43.

Razowska-Jaworek, L., 2014, Calcium and magnesium in groundwater, occurrence and significance for human health: Boca Raton, Taylor \& Francis Group, LLC, $221 \mathrm{p}$.

Rusydi, A.F., 2018, Correlation between conductivity and total dissolved solid in various type of water: A review: IOP Conference Series: Earth and Environmental Science, v. 118, doi:10.1088/1755-1315/118/1/012019.

Sappa, G., Ergul, S., and Ferranti. F., 2014, Water quality assessment of carbonate aquifers in southern Latium region, Central Italy: a case study for irrigation and drinking purposes: Appl Water Sci 4, 115-128, https://doi.org/10.1007/s13201-013-0135-9

SAS Institute Inc., 2018, SAS/STAT® 15.1 User’s Guide, Cary, NC.

Schumacher, J.G., and Kleeschulte, M.J., 2010, Investigation of a monitoring well completed in the St . Francois Aquifer in Oregon County, Missouri, 2005 - 08 USGS - Scientific Investigations Report 2010 - 5041:, doi:10.3133/sir20105041.

Shuster, E.T., and White, W.B., 1971, Seasonal fluctuations in the chemistry of limestone springs: A possible means for characterizing carbonate aquifers: Journal of Hydrology, doi:10.1016/0022-1694(71)90001-1.

State of Missouri, 2020, Code of state regualtions, https://www.sos.mo.gov/adrules/csr/current/10csr/10csr\#10-60

Tabachnick, B. G., and Fidell, L. S., 2013, Using multivariate statistics, $6^{\text {th }}$ edition, doi:10.1007/978-94-009-1217-5.

Tharwat, A., Gaber, T., Ibrahim, A., and Hassanien, A.E., 2017, Linear discriminant analysis: A detailed tutorial: AI Communications, v. 30, p. 169-190, doi:10.3233/AIC-170729.

Thompson, T.L., 1991, Paleozoic succession in Missouri part 2 Ordovician system: Missouri Department of Natural Resources' Division of Geology and Land Survey, Report of Investigations 70 Part 2, p. 202.

Thyne, G.D., 2007, PHREEQC Manual for short course: Science Based Solutions LLC. 
U.S. EPA., 2018, Drinking water standards and health advisories tables: https://www.epa.gov/sdwa/2018-drinking-water-standards-and-advisory-tables

U.S. EPA., 2015, Method 6020B, revision 2 and method 6010D, revision 4: Test methods for evaluating solid waste, physical/chemical methods, EPA publication SW-846, Third Edition, Final Updates 2015, https://www.epa.gov/hw-sw846/sw-846-compendium (accesed January, 2020)

Vandike, J.E., 1979, Hydrogeology of the North Fork River basin above Tecumseh, Missouri, Missouri Speleology, v. 19, no. 1 and 2, 77p.

Vineyard, J.D., and Feder, G.L., 1974, Springs of Missouri: Missouri Geological Survey and Water Resources, Water Resources Report Number 29, p. 212.

Walk, M., Chase, R., and Screpetis, A., 2001, Standard operating procedures rivers-4 For pH and alkalinity: Massachusetts Water Watch Partnership, p. 1-12.

Watershed Committee of the Ozarks, 2017, Springs and groundwater: Early warning systems for our groundwater, p. 2, https://watershedcommittee.org/wp-content/uploads/2017/02/WCOSprings-Factsheet.pdf.

Weary, D.J., Harrison, R.W., Orndorff, R.C., Weems, R.E., Schindler, J.S., Repetski, J.E., and Pierce, H.A., 2014, Bedrock geologic map of the Spring Valley, West Plains, and parts of the Piedmont and Poplar Bluff 30' $\times$ 60' Quadrangles, Missouri, Including the upper Current River and Eleven Point River drainage basins: U.S. Geological Survey Scientific Investigations Map 3280, 2 sheets, scale 1:100,000, p. 55, doi:http://dx.doi.org/10.3133/sim3280. 


\begin{tabular}{|c|c|c|c|c|c|c|c|c|c|c|}
\hline Date & Location & $\mathbf{C u}$ & $\mathbf{K}$ & $\mathbf{N i}$ & $\mathbf{V}$ & Mn & $\mathbf{B a}$ & $\mathbf{Z n}$ & $\mathbf{T i}$ & Sn \\
\hline & & $(\mathrm{ug} / \mathrm{L})$ & $(\mathrm{mg} / \mathrm{L})$ & $(\mathrm{ug} / \mathrm{L})$ & $(\mathrm{ug} / \mathrm{L})$ & $(\mathrm{ug} / \mathrm{L})$ & $(\mathrm{ug} / \mathrm{L})$ & $(\mathrm{ug} / \mathrm{L})$ & $(\mathrm{ug} / \mathrm{L})$ & $(\mathrm{ug} / \mathrm{L})$ \\
\hline \multirow[t]{4}{*}{$6 / 2 / 2019$} & Big Spring & 0.75 & 1.02 & $<.5$ & $<1$ & $<.5$ & 29.7 & 3.38 & 3.65 & 10.7 \\
\hline & Greer Spring & 1.49 & 1.71 & $<.5$ & $<1$ & 0.52 & 34 & 5.02 & 1.74 & 8.58 \\
\hline & Hodgson Mill Spring & 0.63 & 2.24 & $<.5$ & $<1$ & $<.5$ & 68.8 & 3.46 & 2.84 & 1.75 \\
\hline & Mammoth Spring & 0.61 & 2.09 & $<.5$ & $<1$ & 1.66 & 41.3 & 17.8 & 4.43 & 1.87 \\
\hline \multirow[t]{4}{*}{$6 / 15 / 2019$} & Big Spring & 2.85 & 1.29 & 2.88 & $<1$ & 0.95 & 30.7 & 7.95 & 2.28 & 3.46 \\
\hline & Greer Spring & 0.66 & 1.63 & 2.11 & 1.35 & $<.5$ & 34.5 & 2.47 & 2.87 & 0.25 \\
\hline & Hodgson Mill Spring & 0.58 & 2.18 & 2.51 & $<1$ & 0.78 & 40.1 & 2.78 & 5.11 & 2.91 \\
\hline & Mammoth Spring & 1.36 & 2.24 & 3.2 & $<1$ & 1.85 & 35.8 & 4.12 & 2.14 & 4.72 \\
\hline \multirow[t]{4}{*}{$6 / 30 / 2019$} & Big Spring & $<0.50$ & $<0.1$ & $<0.50$ & $<1$ & $<0.50$ & 30.6 & 1.47 & 8.54 & 2.65 \\
\hline & Greer Spring & $<0.50$ & 0.59 & $<0.50$ & $<1$ & 2.87 & 36.6 & 0.88 & 5.73 & $<0.50$ \\
\hline & Hodgson Mill Spring & $<0.50$ & 1.03 & $<0.50$ & $<1$ & $<0.50$ & 41.1 & 2.82 & 10.1 & 1.27 \\
\hline & Mammoth Spring & $<0.50$ & 1.38 & $<0.50$ & $<1$ & 1.23 & 36.3 & 2.68 & 12.2 & 1.27 \\
\hline \multirow[t]{4}{*}{$7 / 13 / 2019$} & Big Spring & $<0.50$ & $<0.1$ & $<0.50$ & $<1$ & $<0.50$ & 31.7 & 1.6 & 8.64 & 1.72 \\
\hline & Greer Spring & $<0.50$ & 0.4 & $<0.50$ & $<1$ & $<0.50$ & 36.7 & 2.1 & 8.43 & $<0.50$ \\
\hline & Hodgson Mill Spring & $<0.50$ & 0.78 & $<0.50$ & $<1$ & $<0.50$ & 41.4 & 3.11 & 8.83 & 0.94 \\
\hline & Mammoth Spring & $<0.50$ & 0.94 & $<0.50$ & $<1$ & 1.31 & 36.7 & 3 & 12.1 & 2.4 \\
\hline \multirow[t]{4}{*}{$7 / 20 / 2019$} & Big Spring & $<0.50$ & $<0.1$ & $<0.50$ & $<1$ & $<0.50$ & 31.8 & 2.15 & 9.64 & 2.95 \\
\hline & Greer Spring & $<0.50$ & 0.39 & $<0.50$ & $<1$ & $<0.50$ & 36.7 & 2.08 & 8.61 & $<0.50$ \\
\hline & Hodgson Mill Spring & $<0.50$ & 0.63 & $<0.50$ & $<1$ & $<0.50$ & 41.1 & 2.9 & 9.67 & 1.96 \\
\hline & Mammoth Spring & $<0.50$ & 0.78 & $<0.50$ & $<1$ & 1 & 36.3 & 2.57 & 11.4 & 5.8 \\
\hline
\end{tabular}




\begin{tabular}{|c|c|c|c|c|c|c|c|c|c|c|}
\hline Date & Location & $\mathrm{Cu}$ & $\mathbf{K}$ & $\mathbf{N i}$ & $\mathbf{V}$ & Mn & $\mathbf{B a}$ & $\mathbf{Z n}$ & Ti & Sn \\
\hline & & $(\mathrm{ug} / \mathrm{L})$ & $(\mathrm{mg} / \mathrm{L})$ & $(\mathrm{ug} / \mathrm{L})$ & $(\mathrm{ug} / \mathrm{L})$ & $(\mathrm{ug} / \mathrm{L})$ & $(\mathrm{ug} / \mathrm{L})$ & $(\mathrm{ug} / \mathrm{L})$ & $(\mathrm{ug} / \mathrm{L})$ & $(\mathrm{ug} / \mathrm{L})$ \\
\hline \multirow[t]{4}{*}{$7 / 27 / 2019$} & Big Spring & $<0.50$ & 0.79 & 2.46 & $<1$ & $<0.50$ & 31.9 & 1.45 & 14.6 & $<0.50$ \\
\hline & Greer Spring & 4.93 & 1.3 & 2.36 & $<1$ & $<0.50$ & 37.6 & 2.14 & 14 & 0.91 \\
\hline & Hodgson Mill Spring & $<0.50$ & 1.53 & 2.82 & $<1$ & $<0.50$ & 41.7 & 2.98 & 17.8 & 2.49 \\
\hline & Mammoth Spring & $<0.50$ & 1.66 & 3.06 & $<1$ & 0.85 & 36.6 & 2.42 & 16.2 & 4.04 \\
\hline \multirow[t]{4}{*}{$8 / 24 / 2019$} & Big Spring & 2.31 & 0.69 & 0.63 & 1.18 & $<0.50$ & 31.8 & 4.04 & $<.5$ & $<0.50$ \\
\hline & Greer Spring & $<0.50$ & 1.25 & $<0.50$ & $<1$ & $<0.50$ & 37.3 & 3.14 & $<.5$ & $<0.50$ \\
\hline & Hodgson Mill Spring & 0.62 & 1.43 & $<0.50$ & 2.67 & $<0.50$ & 40.5 & 4.33 & $<.5$ & $<0.50$ \\
\hline & Mammoth Spring & 2.69 & 1.6 & 0.84 & $<1$ & 1.77 & 38 & 7.82 & $<.5$ & 3.17 \\
\hline \multirow[t]{4}{*}{ 9/7/2019 } & Big Spring & $<0.50$ & 0.67 & 1.82 & 1.39 & $<0.50$ & 29.4 & 1.9 & 16.5 & $<0.50$ \\
\hline & Greer Spring & $<0.50$ & 1.47 & 1.84 & 1.24 & $<0.50$ & 64.6 & 5.68 & 16.5 & 1.2 \\
\hline & Hodgson Mill Spring & $<0.50$ & 2.1 & 2.06 & 1.23 & $<0.50$ & 39.2 & 3.06 & 18.7 & $<0.50$ \\
\hline & Mammoth Spring & $<0.50$ & 1.91 & 2.27 & $<1$ & 0.99 & 34.1 & 2.67 & 20 & 6.3 \\
\hline \multirow[t]{4}{*}{$9 / 28 / 2019$} & Big Spring & $<0.50$ & 0.8 & 1.57 & 1.67 & $<0.50$ & 28.1 & 1.16 & 16 & $<0.50$ \\
\hline & Greer Spring & $<0.50$ & 1.47 & 1.65 & 2.56 & $<0.50$ & 33.7 & 1.58 & 17.2 & 1.1 \\
\hline & Hodgson Mill Spring & $<0.50$ & 1.7 & 1.96 & 1.85 & $<0.50$ & 37 & 2.4 & 19 & $<0.50$ \\
\hline & Mammoth Spring & $<0.50$ & 1.75 & 2.05 & 1.54 & 0.81 & 32.7 & 2.18 & 19.6 & 5.76 \\
\hline \multirow[t]{4}{*}{$10 / 13 / 2019$} & Big Spring & $<0.50$ & $<0.1$ & 2.13 & $<1$ & $<0.50$ & 29.2 & 1.25 & 17.6 & $<0.50$ \\
\hline & Greer Spring & $<0.50$ & 0.79 & 2.27 & $<1$ & $<0.50$ & 35.2 & 1.47 & 17 & $<0.50$ \\
\hline & Hodgson Mill Spring & $<0.50$ & 1.27 & 2.57 & 1.26 & $<0.50$ & 41.9 & 3.14 & 19.6 & $<0.50$ \\
\hline & Mammoth Spring & $<0.50$ & 0.98 & 2.76 & $<1$ & 0.66 & 34.7 & 2.24 & 22.5 & 3.66 \\
\hline
\end{tabular}




\begin{tabular}{|c|c|c|c|c|c|c|c|c|c|c|c|c|}
\hline Date & Location & pH & Temp. & Cond. & Alk. & $\mathrm{Ca}$ & Mg & Iron & Nitrogen & Sulfate & $\mathbf{N a}$ & Cl \\
\hline & & & $\left({ }^{\circ} \mathrm{C}\right)$ & $(\mathrm{uS} / \mathrm{cm})$ & $\begin{array}{c}\text { (CaCO3, } \\
\mathrm{mg} / \mathrm{L})\end{array}$ & $(\mathrm{mg} / \mathrm{L})$ & $(\mathrm{mg} / \mathrm{L})$ & (ug/L) & $(\mathrm{mg} / \mathrm{L})$ & $(\mathrm{mg} / \mathrm{L})$ & $(\mathrm{mg} / \mathrm{L})$ & $(\mathrm{mg} / \mathrm{L})$ \\
\hline \multirow[t]{4}{*}{$6 / 2 / 2019$} & Big Spring & 7.06 & 18.5 & 259 & 108 & 30.6 & 17.5 & 3.53 & 0.6 & 5.09 & 1.39 & $<1.5$ \\
\hline & Greer Spring & 7.1 & 16.6 & 260 & 116 & 28.7 & 16.4 & 9.37 & 1.11 & 5.72 & 1.81 & 2.64 \\
\hline & $\begin{array}{l}\text { Hodgson Mill } \\
\text { Spring }\end{array}$ & 7.08 & 19.7 & 340 & 170 & 37 & 21 & 4.97 & 1.97 & 6.51 & 2.44 & 5.08 \\
\hline & Mammoth Spring & 6.98 & 19.8 & 389 & 177.8 & 44.7 & 24.8 & 4.91 & 1.64 & 7.06 & 2.73 & 4.58 \\
\hline \multirow[t]{4}{*}{$6 / 15 / 2019$} & Big Spring & 7.3 & 16.6 & 308 & 111 & 35.8 & 20.3 & 4.01 & 0.62 & 3.53 & 1.81 & 1.76 \\
\hline & Greer Spring & 7.05 & 15.4 & 290 & 88 & 32.7 & 18.9 & 5.94 & 1.17 & 4.03 & 1.71 & 2.5 \\
\hline & $\begin{array}{l}\text { Hodgson Mill } \\
\text { Spring }\end{array}$ & 7.07 & 19.5 & 355 & 185 & 38.8 & 22.1 & 12.4 & 1.79 & 4.92 & 2.32 & 4.94 \\
\hline & Mammoth Spring & 7.18 & 20.6 & 405 & 185 & 47 & 27 & 5.26 & 1.57 & 5.32 & 2.65 & 4.52 \\
\hline \multirow[t]{4}{*}{$6 / 30 / 2019$} & Big Spring & 7.26 & 19.8 & 319 & 76 & 35.6 & 21.5 & $<1$ & 0.61 & 6.16 & 1.39 & $<1.5$ \\
\hline & Greer Spring & 7.13 & 16.4 & 310 & 74 & 33.8 & 20.4 & 18.1 & 1.21 & 5.8 & 1.54 & 2.14 \\
\hline & $\begin{array}{l}\text { Hodgson Mill } \\
\text { Spring }\end{array}$ & 7.2 & 19.2 & 380 & 139 & 41.5 & 24.8 & $<1$ & 1.85 & 7.77 & 2.28 & 5.53 \\
\hline & Mammoth Spring & 7.16 & 21.4 & 394 & 168 & 44.4 & 26.2 & 5.38 & 1.57 & 5.76 & 2.22 & 4.42 \\
\hline \multirow[t]{4}{*}{$7 / 13 / 2019$} & Big Spring & 7.38 & 17.7 & 340 & 90 & 37.5 & 22.9 & $<1$ & 0.6 & $<3.50$ & 1.36 & $<1.5$ \\
\hline & Greer Spring & 7.27 & 15.7 & 323 & 62 & 36.1 & 21.4 & $<1$ & 1.14 & 4.32 & 1.57 & $<1.5$ \\
\hline & $\begin{array}{l}\text { Hodgson Mill } \\
\text { Spring }\end{array}$ & 7.28 & 18.4 & 408 & 251 & 45.4 & 26.4 & $<1$ & 1.61 & 5.41 & 2.32 & 4.58 \\
\hline & Mammoth Spring & 7.18 & 21.2 & 422 & 184 & 49.5 & 29.4 & $<1$ & 1.44 & 5.44 & 2.29 & 3.04 \\
\hline
\end{tabular}




\begin{tabular}{|c|c|c|c|c|c|c|c|c|c|c|c|c|}
\hline Date & Location & pH & Temp. & Cond. & Alk. & $\mathrm{Ca}$ & Mg & Iron & Nitrogen & Sulfate & $\mathbf{N a}$ & Cl \\
\hline & & & $\left({ }^{\circ} \mathrm{C}\right)$ & (uS/cm) & $\begin{array}{c}\text { (CaCO3, } \\
\mathrm{mg} / \mathrm{L})\end{array}$ & $(\mathrm{mg} / \mathrm{L})$ & $(\mathrm{mg} / \mathrm{L})$ & $(\mathrm{ug} / \mathrm{L})$ & $(\mathrm{mg} / \mathrm{L})$ & $(\mathrm{mg} / \mathrm{L})$ & $(\mathrm{mg} / \mathrm{L})$ & $(\mathrm{mg} / \mathrm{L})$ \\
\hline \multirow[t]{4}{*}{$7 / 20 / 2019$} & Big Spring & 7.3 & 18.9 & 360 & 133 & 39.8 & 23.6 & $<1$ & 0.56 & 4.53 & 1.44 & $<1.5$ \\
\hline & Greer Spring & 7.29 & 16.2 & 348 & 171 & 39.3 & 23.6 & $<1$ & 1.09 & $<3.50$ & 1.66 & 1.5 \\
\hline & $\begin{array}{l}\text { Hodgson Mill } \\
\text { Spring }\end{array}$ & 7.25 & 17.9 & 405 & 137 & 44.6 & 26.1 & $<1$ & 1.59 & 6.34 & 2.22 & 4.82 \\
\hline & Mammoth Spring & 7.08 & 19.7 & 432 & 215 & 51.7 & 29.2 & $<1$ & 1.38 & 6.47 & 2.1 & 3.77 \\
\hline \multirow{4}{*}{ 7/27/2019 } & Big Spring & 7.37 & 16.3 & 356 & 88 & 39.7 & 22.7 & 14.8 & 0.62 & $<3.50$ & 1.49 & 2.51 \\
\hline & Greer Spring & 7.25 & 16.4 & 361 & 128 & 38.3 & 21.9 & 20.2 & 1.1 & $<3.50$ & 1.59 & 3.75 \\
\hline & $\begin{array}{l}\text { Hodgson Mill } \\
\text { Spring }\end{array}$ & 7.33 & 18.4 & 416 & 230 & 46 & 25.9 & 16.7 & 0.62 & 5.96 & 2.16 & 5.28 \\
\hline & Mammoth Spring & 7.17 & 19 & 439 & 244 & 48.3 & 27.9 & 41.5 & 1.34 & 4.11 & 2.07 & 4.83 \\
\hline \multirow[t]{4}{*}{$8 / 24 / 2019$} & Big Spring & 7.29 & 15.7 & 370 & 241 & 38.2 & 23.1 & 2.05 & 0.63 & $<3.50$ & 1.74 & 1.61 \\
\hline & Greer Spring & 7.2 & 15.7 & 360 & 155 & 38.9 & 23.4 & $<1$ & 1.23 & $<3.50$ & 1.66 & 2.56 \\
\hline & $\begin{array}{l}\text { Hodgson Mill } \\
\text { Spring }\end{array}$ & 7.28 & 15.4 & 433 & 198 & 44.5 & 26.1 & $<1$ & 1.64 & 4.29 & 2.13 & 5.21 \\
\hline & Mammoth Spring & 7.2 & 17.6 & 467 & 215 & 47.9 & 28.7 & $<1$ & 1.38 & 5.29 & 2.09 & 3.86 \\
\hline \multirow[t]{4}{*}{ 9/7/2019 } & Big Spring & 7.32 & 15.8 & 370 & 213 & 40.8 & 23.7 & $<1$ & 0.55 & $<3.50$ & 1.62 & 1.52 \\
\hline & Greer Spring & 7.25 & 15.3 & 342 & 156 & 38.2 & 22 & $<1$ & 1.19 & $<3.50$ & 1.86 & 2.58 \\
\hline & $\begin{array}{l}\text { Hodgson Mill } \\
\text { Spring }\end{array}$ & 7.17 & 16.4 & 397 & 202 & 42.7 & 24 & $<1$ & 1.75 & 4.55 & 2.31 & 4.78 \\
\hline & Mammoth Spring & 7.16 & 17.4 & 437 & 201 & 47.5 & 27.1 & 1.61 & 1.31 & 3.85 & 2.04 & 3.42 \\
\hline
\end{tabular}




\begin{tabular}{|c|c|c|c|c|c|c|c|c|c|c|c|c|}
\hline Date & Location & pH & Temp. & Cond. & Alk. & $\mathrm{Ca}$ & Mg & Iron & Nitrogen & Sulfate & $\mathbf{N a}$ & Cl \\
\hline & & & $\left({ }^{\circ} \mathrm{C}\right)$ & $(\mathrm{uS} / \mathrm{cm})$ & $\begin{array}{c}\text { (CaCO3, } \\
\mathrm{mg} / \mathrm{L})\end{array}$ & $(\mathrm{mg} / \mathrm{L})$ & $(\mathrm{mg} / \mathrm{L})$ & $(\mathrm{ug} / \mathrm{L})$ & $(\mathrm{mg} / \mathrm{L})$ & $(\mathrm{mg} / \mathrm{L})$ & $(\mathrm{mg} / \mathrm{L})$ & $(\mathrm{mg} / \mathrm{L})$ \\
\hline \multirow[t]{4}{*}{$9 / 28 / 2019$} & Big Spring & 7.32 & 15.5 & 400 & 109 & 40.9 & 23.6 & $<1$ & 0.5 & 3.86 & 1.62 & 2 \\
\hline & Greer Spring & 7.27 & 15.8 & 366 & 128 & 40.1 & 23 & $<1$ & 1.17 & 4.11 & 1.72 & 2.55 \\
\hline & $\begin{array}{l}\text { Hodgson Mill } \\
\text { Spring }\end{array}$ & 7.28 & 16.3 & 416 & 173 & 48.4 & 26.4 & $<1$ & 1.57 & 5.62 & 2.1 & 5 \\
\hline & Mammoth Spring & 7.21 & 18.2 & 438 & 148 & 49.9 & 28.7 & $<1$ & 1.27 & 5.02 & 1.96 & 3.37 \\
\hline \multirow[t]{4}{*}{$10 / 13 / 2019$} & Big Spring & 7.38 & 14.3 & 367 & 186 & 39.9 & 23.5 & $<1$ & 0.44 & 4.15 & 1.4 & 2.67 \\
\hline & Greer Spring & 7.4 & 13.8 & 374 & 81 & 39.2 & 23.5 & $<1$ & 1.02 & 4.15 & 1.46 & 2.25 \\
\hline & $\begin{array}{l}\text { Hodgson Mill } \\
\text { Spring }\end{array}$ & 7.31 & 13.6 & 444 & 201 & 45.9 & 26.6 & $<1$ & 2.09 & 5.32 & 2.46 & 6.67 \\
\hline & Mammoth Spring & 7.38 & 14.5 & 470 & 170 & 48.3 & 28.9 & $<1$ & 1.1 & 4.88 & 1.76 & 3.03 \\
\hline
\end{tabular}


Appendix B - Statistical Data
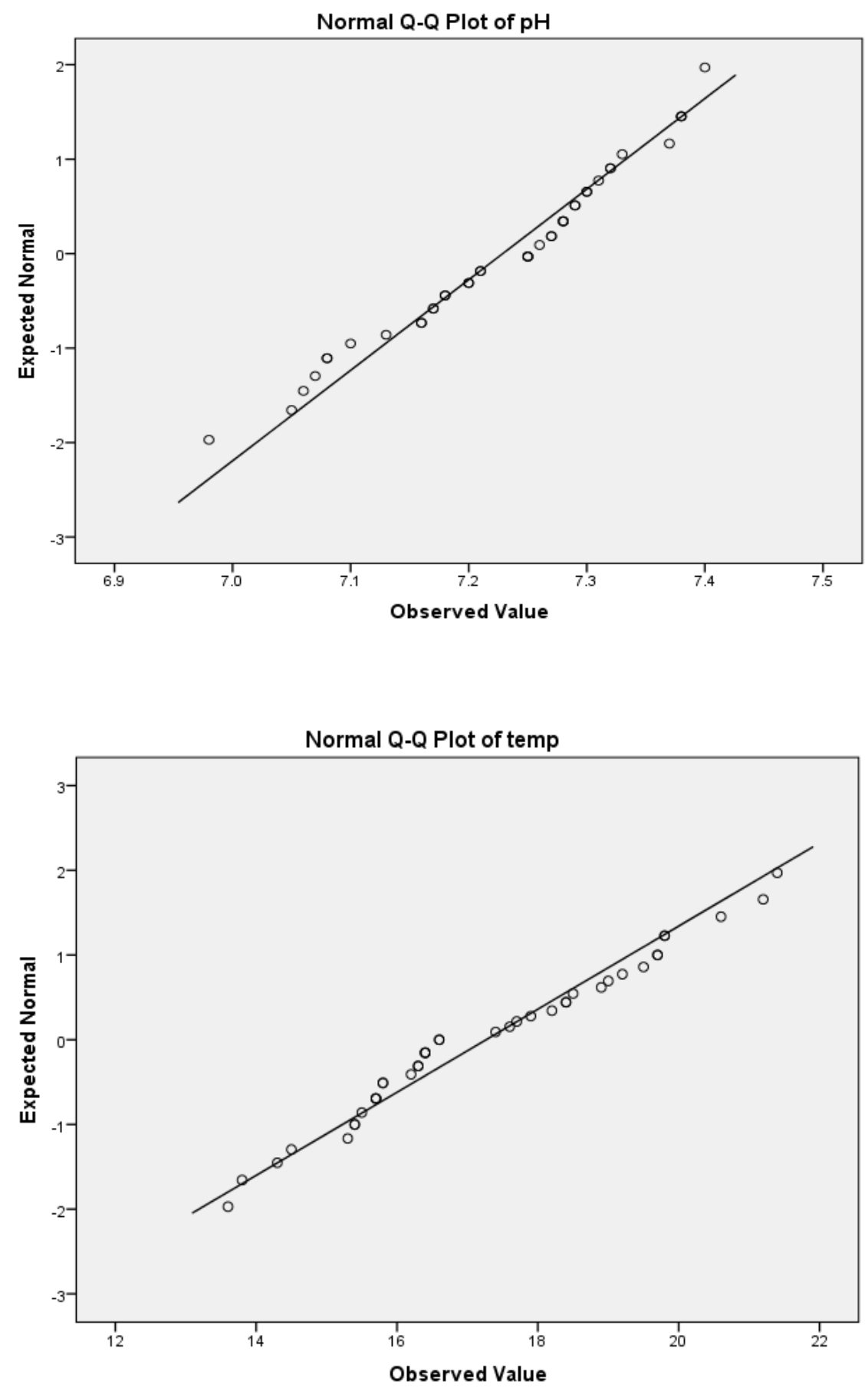

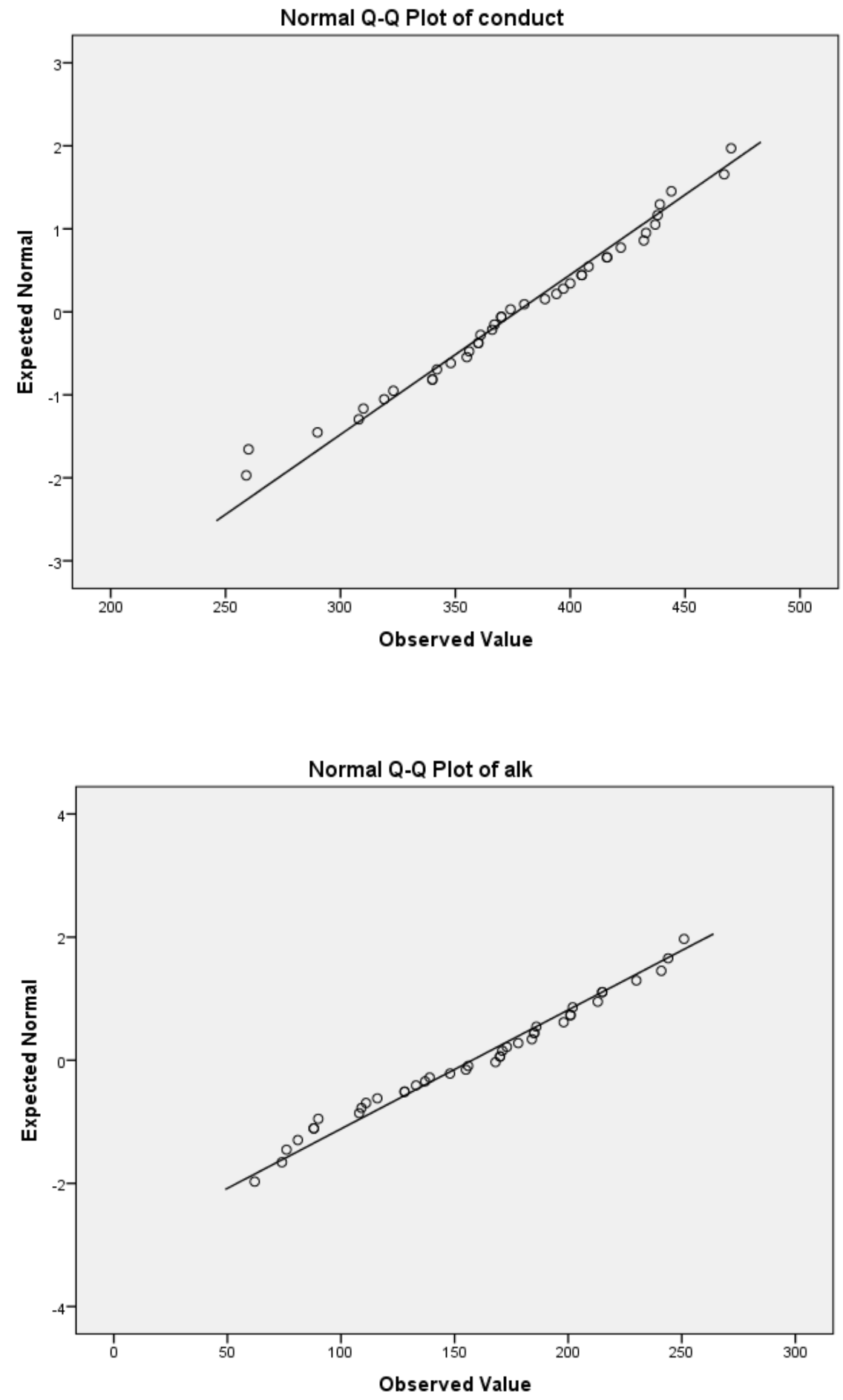

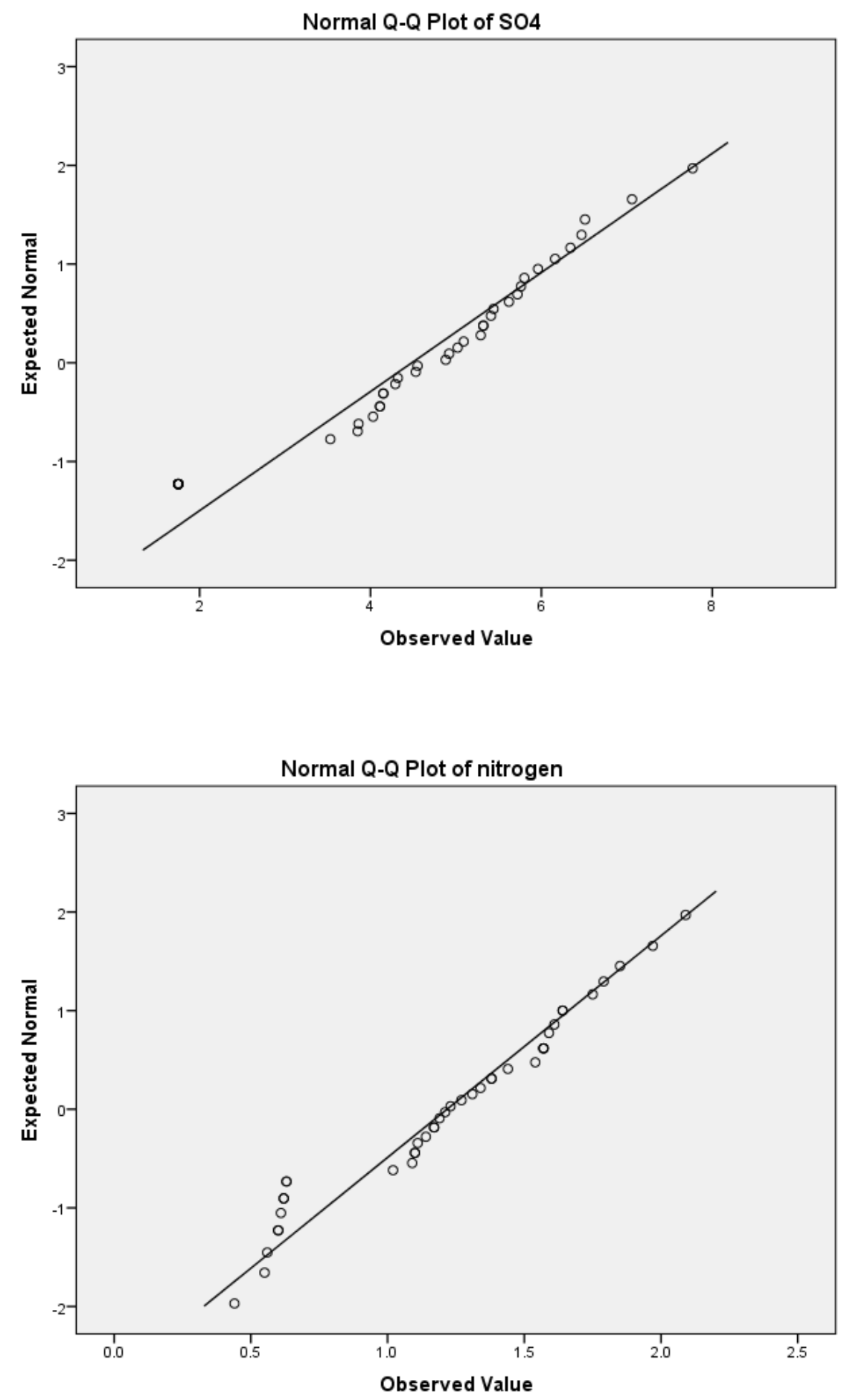

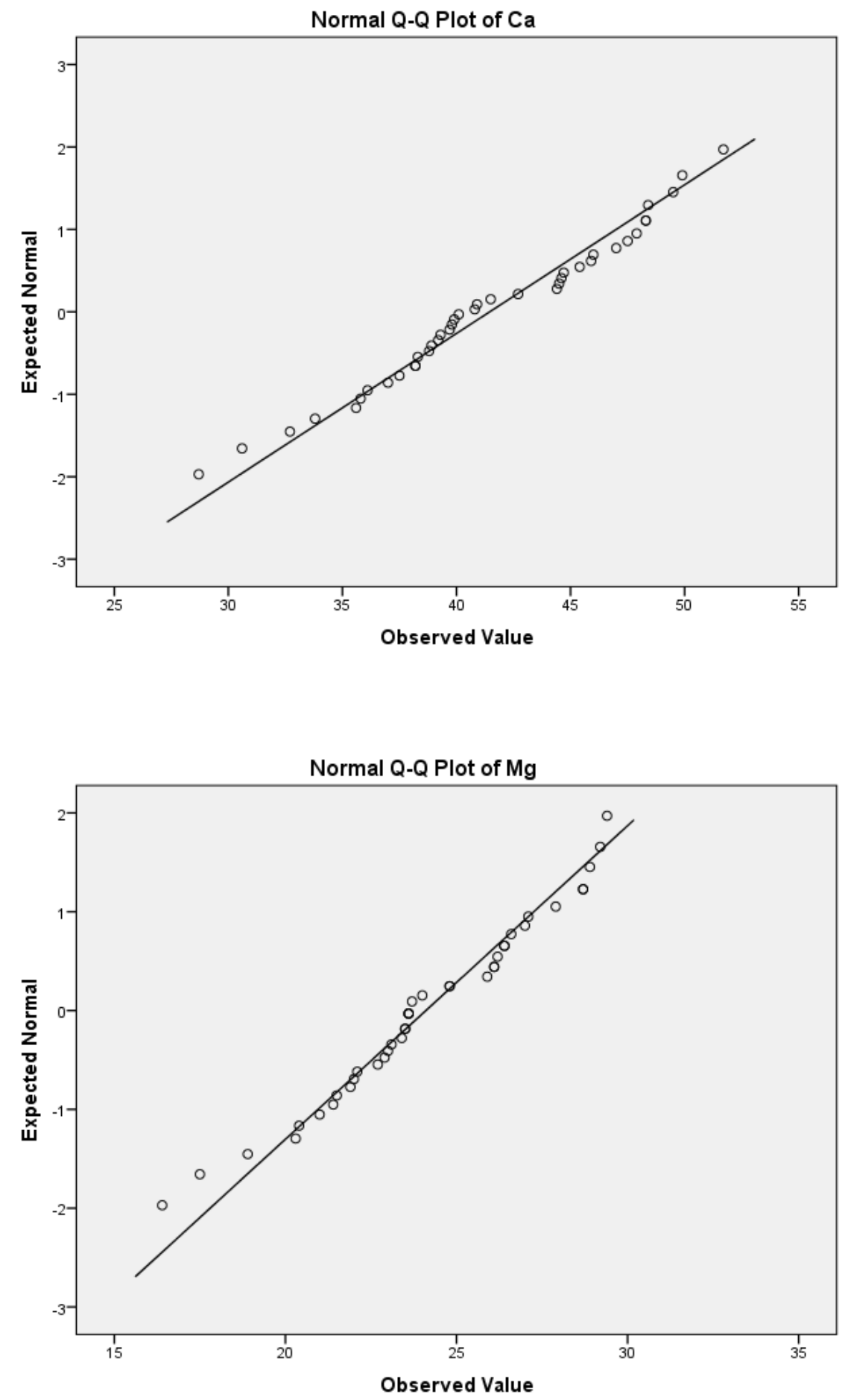


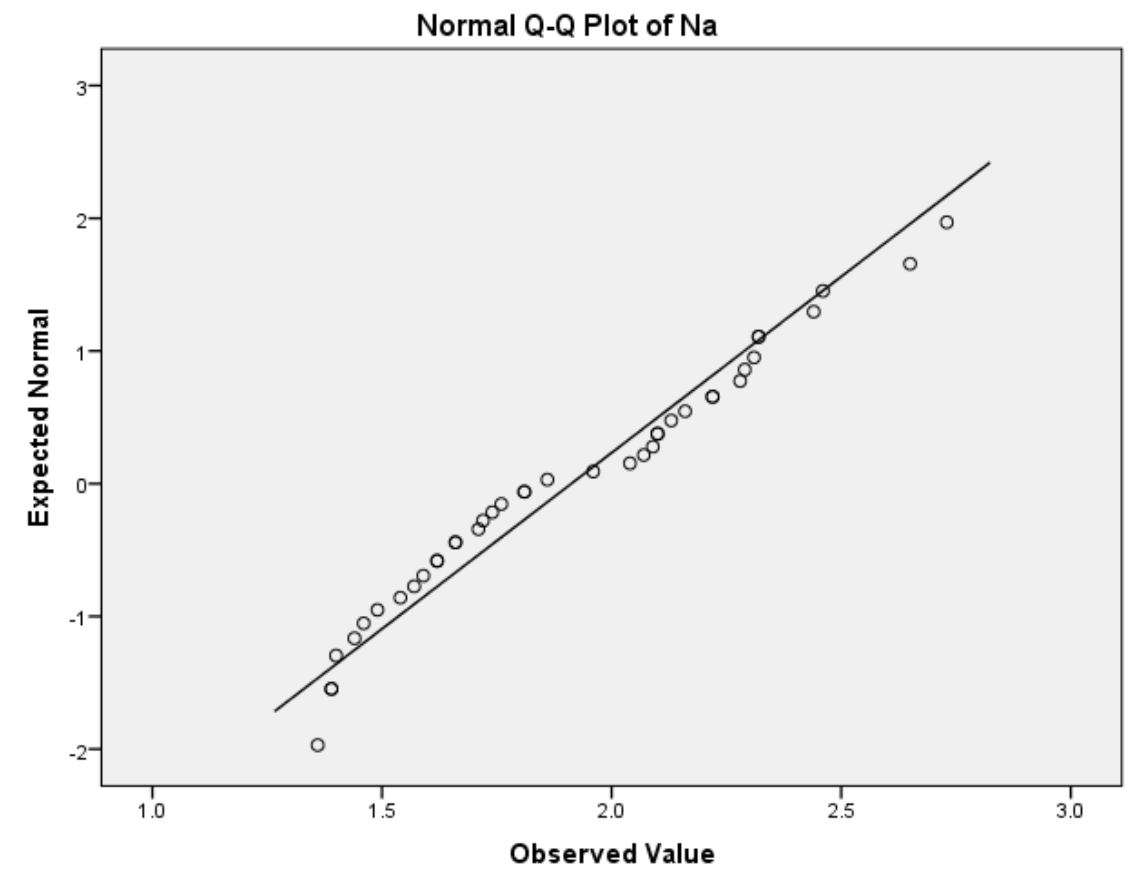

SAS 9.4 Linear Discriminant Analysis Model One Output Model One Squared Distance to Basin

From Basin

Big Spring

Greer Spring

Hodgson Mill Spring

Mammoth Spring
Big Spring Greer Spring Hodgson Mill Spring Mammoth Spring

$0 \quad 27.07637$

97.01405

71.12383

27.07637

0

29.38633

0

27.29814

97.01405

29.38633

10.41478
27.29814
71.12383

27.29814

Prob > Mahalanobis Distance for Squared Distance to Basin Model One

From Basin

Big Spring

Greer Spring

Hodgson Mill Spring

Mammoth Spring
Big Spring Greer Spring

$\begin{array}{ll}1.0000 & <.0001 \\ <.0001 & 1.0000 \\ <.0001 & <.0001 \\ <.0001 & <.0001\end{array}$

Hodgson Mill Spring

Mammoth Spring

$<.0001$

$<.0001$

$<.0001$

$<.0001$

1.0000

$<.0001$

$<.0001$

1.0000 
The DISCRIM Procedure

Classification Summary for Calibration Data: WORK.MODELONE Cross-validation Summary using Linear Discriminant Function

Number of Observations and Percent Classified into Basin

From Basin

Big Spring

$\begin{array}{rr}8 & 0 \\ 100.00 & 0.00\end{array}$

Greer Spring

Hodgson Mill Spring

$\begin{array}{rr}0 & 8 \\ 0.00 & 100.00\end{array}$

0

0.00

0

0.00

0

0.00

12.50

8

25.00

0.25

0.25

9

28.13

18.75

0.25

0.25 Spring

Priors

$\begin{array}{llll}0.25 & 0.25 & 0.25 & 0.25\end{array}$

Error Count Estimates for Basin

Big Spring Greer Spring Hodgson Mill Mammoth Spring Total Spring

$\begin{array}{llllll}\text { Rate } & 0.0000 & 0.0000 & 0.2500 & 0.1250 & 0.0938 \\ \text { Priors } & 0.2500 & 0.2500 & 0.2500 & 0.2500\end{array}$


The DISCRIM Procedure

Classification Summary for Calibration Data: WORK.MODELONE Cross-validation Summary using Linear Discriminant Function

Number of Observations and Percent Classified into Basin

From Basin

Big Spring
Big Spring G

100.00

Greer Spring

Hodgson Mill Spring

Mammoth Spring

0
0.00

0

0.00

0

0.00

Priors
Greer Spring

$$
\text { g Hodgs }
$$

\section{Spring}

$\begin{array}{rrr}0 & 0 & 8 \\ 0.00 & 0.00 & 100.00\end{array}$

0.00

0

$\begin{array}{ll}0 & 8\end{array}$

0.00

$0.00 \quad 100.00$

$$
100.00
$$

0.00

6

75.00

$\begin{array}{rr}2 & 8\end{array}$

0.00

0

0.00

0

0.00

$\begin{array}{rr}8 & 8 \\ 100.00 & 100.00\end{array}$

\section{Total}

8

25.00

0.25

8
25.00

8

$$
25.00
$$

6

18.75

0.25

0.25 8

o


The DISCRIM Procedure

Classification Summary for Calibration Data: WORK.MODELONE Cross-validation Summary using Linear Discriminant Function

Number of Observations and Percent Classified into Basin

From Basin

Big Spring
Big Spring G

100.00

Greer Spring

Hodgson Mill Spring

Mammoth Spring

0
0.00

0

0.00

0

0.00

8

25.00

0.25

0.25

0.25

0.25

Error Count Estimates for Basin

Big Spring Greer Spring Hodgson Mill Mammoth Spring Total Spring

$\begin{array}{llllll}\text { Rate } & 0.0000 & 0.0000 & 0.2500 & 0.0000 & 0.0625 \\ \text { Priors } & 0.2500 & 0.2500 & 0.2500 & 0.2500\end{array}$


The DISCRIM Procedure

Classification Results for Calibration Data: WORK.MODELONE

Resubstitution Results using Linear Discriminant Function

Posterior Probability of Membership in Basin

\begin{tabular}{|c|c|c|c|c|c|c|}
\hline ID From Basin & $\begin{array}{l}\text { Classified into } \\
\text { Basin }\end{array}$ & & $\begin{array}{r}\text { Big } \\
\text { Spring }\end{array}$ & $\begin{array}{r}\text { Greer } \\
\text { Spring }\end{array}$ & $\begin{array}{r}\text { Hodgson Mill } \\
\text { Spring }\end{array}$ & $\begin{array}{r}\text { Mammoth } \\
\text { Spring }\end{array}$ \\
\hline $25 \begin{array}{l}\text { Hodgson Mill } \\
\text { Spring }\end{array}$ & $\begin{array}{l}\text { Mammoth } \\
\text { Spring }\end{array}$ & * & 0.0000 & 0.0000 & 0.1415 & 0.85 \\
\hline
\end{tabular}

${ }^{*}$ Misclassified observation

The DISCRIM Procedure

Classification Results for Calibration Data: WORK.MODELONE Cross-validation Results using Linear Discriminant Function

Posterior Probability of Membership in Basin

\begin{tabular}{|c|c|c|c|c|c|c|c|}
\hline ID & From Basin & $\begin{array}{l}\text { Classified into } \\
\text { Basin }\end{array}$ & & $\begin{array}{r}\text { Big } \\
\text { Spring }\end{array}$ & $\begin{array}{r}\text { Greer } \\
\text { Spring }\end{array}$ & $\begin{array}{r}\text { Hodgson Mill } \\
\text { Spring }\end{array}$ & $\begin{array}{r}\text { Mammoth } \\
\text { Spring }\end{array}$ \\
\hline 24 & $\begin{array}{l}\text { Hodgson Mill } \\
\text { Spring }\end{array}$ & $\begin{array}{l}\text { Mammoth } \\
\text { Spring }\end{array}$ & $*$ & 0.0000 & 0.0000 & 0.0046 & 0.9954 \\
\hline 25 & $\begin{array}{l}\text { Hodgson Mill } \\
\text { Spring }\end{array}$ & $\begin{array}{l}\text { Mammoth } \\
\text { Spring }\end{array}$ & * & 0.0000 & 0.0000 & 0.0250 & 0.9750 \\
\hline \multicolumn{8}{|c|}{${ }^{*}$ Misclassified observation } \\
\hline \multicolumn{8}{|c|}{$\begin{array}{l}\text { The DISCRIM Procedure } \\
\text { Classification Results for Calibration Data: WORK.MODELONE } \\
\text { Cross-validation Results using Linear Discriminant Function }\end{array}$} \\
\hline \multicolumn{8}{|c|}{ Posterior Probability of Membership in Basin } \\
\hline ID & From Basin & $\begin{array}{l}\text { Classified into } \\
\text { Basin }\end{array}$ & & $\begin{array}{r}\text { Big } \\
\text { Spring }\end{array}$ & $\begin{array}{r}\text { Greer } \\
\text { Spring }\end{array}$ & $\begin{array}{r}\text { Hodgson Mill } \\
\text { Spring }\end{array}$ & $\begin{array}{r}\text { Mammoth } \\
\text { Spring }\end{array}$ \\
\hline 24 & $\begin{array}{l}\text { Hodgson Mill } \\
\text { Spring }\end{array}$ & $\begin{array}{l}\text { Mammoth } \\
\text { Spring }\end{array}$ & * & 0.0000 & 0.0000 & 0.3626 & 0.6374 \\
\hline 25 & $\begin{array}{l}\text { Hodgson Mill } \\
\text { Spring }\end{array}$ & $\begin{array}{l}\text { Mammoth } \\
\text { Spring }\end{array}$ & * & 0.0000 & 0.0000 & 0.0072 & 0.9928 \\
\hline
\end{tabular}


Squared Distance to Basin Model Two

From Basin Big Spring Greer Spring Hodgson Mill Spring Mammoth Spring

$\begin{array}{llll}\text { Big Spring } & 0 & 27.23572 & 103.39264\end{array}$

$\begin{array}{lllll}\text { Greer Spring } & 27.23572 & 0 & 33.29041 & 25.83871\end{array}$

$\begin{array}{lllll}\text { Hodgson Mill Spring } & 103.39264 & 33.29041 & 0 & 11.86618\end{array}$

$\begin{array}{lllll}\text { Mammoth Spring } & 66.28622 & 25.83871 & 11.86618 & 0\end{array}$

Prob > Mahalanobis Distance for Squared Distance to Basin Model Two

From Basin Big Spring Greer Spring Hodgson Mill Spring Mammoth Spring

\begin{tabular}{|c|c|c|c|c|}
\hline Big Spring & 1.0000 & $<.0001$ & $<.0001$ & $<.0001$ \\
\hline Greer Spring & $<.0001$ & 1.0000 & $<.0001$ & $<.0001$ \\
\hline Hodgson Mill Spring & $<.0001$ & $<.0001$ & 1.0000 & 0.0035 \\
\hline Mammoth Spring & $<.0001$ & $<.0001$ & 0.0035 & 1.0000 \\
\hline
\end{tabular}


The DISCRIM Procedure

Classification Summary for Calibration Data: WORK.MODELTWO

Cross-validation Summary using Linear Discriminant Function

Number of Observations and Percent Classified into Basin

From Basin

Big Spring

Big Spring Grecting

100.00

Greer Spring

Hodgson Mill Spring

Mammoth Spring

0
0.00

0

0.00

0

0

0.00

8

25.00

0.25

Priors

Total

$\begin{array}{llll}0.25 & 0.25 & 0.25 & 0.25\end{array}$

Error Count Estimates for Basin

Big Spring Greer Spring Hodgson Mill Mammoth Spring Total Spring

$\begin{array}{llllll}\text { Rate } & 0.0000 & 0.0000 & 0.1250 & 0.2500 & 0.0938 \\ \text { Priors } & 0.2500 & 0.2500 & 0.2500 & 0.2500\end{array}$


The DISCRIM Procedure

Classification Summary for Calibration Data: WORK.MODELTWO

Cross-validation Summary using Linear Discriminant Function

Number of Observations and Percent Classified into Basin

From Basin

Big Spring
Big Spring G

100.00

0

0.00

0

0.00

0

0.00

8

25.00

0.25

8
25.00

$$
0
$$

0.00

8

100.00

Hodgs

\section{Spring}

Hodgson Mill Spring

Mammoth Spring

Total

Priors

8
25.00

0.25

0.25

$\begin{array}{rr}0 & 8 \\ 0.00 & 100.00\end{array}$

0

0.00

$\begin{array}{ll}0 & 8\end{array}$

$0.00 \quad 100.00$

7

87.50

$12.50 \quad 100.00$

$\begin{array}{rr}7 & 8 \\ 87.50 & 100.00\end{array}$

12.50

8

$\begin{array}{rr}8 & 32 \\ 25.00 & 100.00\end{array}$

0.25

Error Count Estimates for Basin

Big Spring Greer Spring Hodgson Mill Mammoth Spring Total Spring

$\begin{array}{llllll}\text { Rate } & 0.0000 & 0.0000 & 0.1250 & 0.1250 & 0.0625 \\ \text { Priors } & 0.2500 & 0.2500 & 0.2500 & 0.2500\end{array}$


The DISCRIM Procedure

Classification Summary for Calibration Data: WORK.MODELTWO

Cross-validation Summary using Linear Discriminant Function

Number of Observations and Percent Classified into Basin

From Basin

Big Spring
Big Spring G

100.00

Greer Spring

Hodgson Mill Spring

Mammoth Spring

0

0.00

0

0.00

0

0.00

8

25.00

0.25

0.25

0.25 Spring

Total

Priors

\begin{tabular}{|c|c|c|c|c|}
\hline \multicolumn{5}{|c|}{ Error Count Estimates for Basin } \\
\hline Big Spring & Greer Spring & $\begin{array}{r}\text { Hodgson Mill } \\
\text { Spring }\end{array}$ & Mammoth Spring & Total \\
\hline 0.0000 & 0.0000 & 0.1250 & 0.0000 & 0.0313 \\
\hline 0.2500 & 0.2500 & 0.2500 & 0.2500 & \\
\hline
\end{tabular}


The DISCRIM Procedure

Classification Results for Calibration Data: WORK.MODELTWO

Cross-validation Results using Linear Discriminant Function

Posterior Probability of Membership in Basin

\begin{tabular}{|c|c|c|c|c|c|c|c|}
\hline ID & From Basin & $\begin{array}{l}\text { Classified into } \\
\text { Basin }\end{array}$ & & $\begin{array}{r}\text { Big } \\
\text { Spring }\end{array}$ & $\begin{array}{r}\text { Greer } \\
\text { Spring }\end{array}$ & $\begin{array}{r}\text { Hodgson Mill } \\
\text { Spring }\end{array}$ & $\begin{array}{r}\text { Mammoth } \\
\text { Spring }\end{array}$ \\
\hline 24 & $\begin{array}{l}\text { Hodgson Mill } \\
\text { Spring }\end{array}$ & $\begin{array}{l}\text { Mammoth } \\
\text { Spring }\end{array}$ & * & 0.0000 & 0.0000 & 0.0180 & 0.9820 \\
\hline 33 & $\begin{array}{l}\text { Mammoth } \\
\text { Spring }\end{array}$ & $\begin{array}{l}\text { Hodgson Mill } \\
\text { Spring }\end{array}$ & * & 0.0000 & 0.0000 & 0.7435 & 0.2564 \\
\hline 40 & $\begin{array}{l}\text { Mammoth } \\
\text { Spring }\end{array}$ & Greer Spring & * & 0.0000 & 0.6062 & 0.0028 & 0.3910 \\
\hline
\end{tabular}

\section{* Misclassified observation}

Classification Results for Calibration Data: WORK.MODELTWO Cross-validation Results using Linear Discriminant Function

Posterior Probability of Membership in Basin

\begin{tabular}{|c|c|c|c|c|c|c|c|}
\hline ID & From Basin & $\begin{array}{l}\text { Classified into } \\
\text { Basin }\end{array}$ & & $\begin{array}{r}\text { Big } \\
\text { Spring }\end{array}$ & $\begin{array}{r}\text { Greer } \\
\text { Spring }\end{array}$ & $\begin{array}{r}\text { Hodgson Mill } \\
\text { Spring }\end{array}$ & $\begin{array}{r}\text { Mammoth } \\
\text { Spring }\end{array}$ \\
\hline 24 & $\begin{array}{l}\text { Hodgson Mill } \\
\text { Spring }\end{array}$ & $\begin{array}{l}\text { Mammoth } \\
\text { Spring }\end{array}$ & * & 0.0000 & 0.0000 & 0.0046 & 0.9954 \\
\hline 33 & $\begin{array}{l}\text { Mammoth } \\
\text { Spring }\end{array}$ & $\begin{array}{l}\text { Hodgson Mill } \\
\text { Spring }\end{array}$ & * & 0.0000 & 0.0000 & 0.6094 & 0.3906 \\
\hline & \multicolumn{7}{|c|}{${ }^{*}$ Misclassified observation } \\
\hline \multicolumn{8}{|c|}{$\begin{array}{l}\text { The DISCRIM Procedure } \\
\text { Classification Results for Calibration Data: WORK.MODELTWO } \\
\text { Cross-validation Results using Linear Discriminant Function }\end{array}$} \\
\hline \multicolumn{8}{|c|}{ Posterior Probability of Membership in Basin } \\
\hline ID & From Basin & $\begin{array}{l}\text { Classified into } \\
\text { Basin }\end{array}$ & & $\begin{array}{r}\text { Big } \\
\text { Spring }\end{array}$ & $\begin{array}{r}\text { Greer } \\
\text { Spring }\end{array}$ & $\begin{array}{r}\text { Hodgson Mill } \\
\text { Spring }\end{array}$ & $\begin{array}{r}\text { Mammoth } \\
\text { Spring }\end{array}$ \\
\hline 24 & $\begin{array}{l}\text { Hodgson Mill } \\
\text { Spring }\end{array}$ & $\begin{array}{l}\text { Mammoth } \\
\text { Spring }\end{array}$ & * & 0.0000 & 0.0000 & 0.0292 & 0.9708 \\
\hline
\end{tabular}

\section{* Misclassified observation}




\begin{tabular}{cccc}
\hline \multicolumn{4}{c}{ Linear discriminant analysis model one run 1 output } \\
\hline ID \# & Actual Basin & Placed Basin & Correct? \\
\hline 20 & Greer Spring & Greer Spring & Yes \\
27 & Hodgson Mill Spring & Hodgson Mill Spring & Yes \\
8 & Big Spring & Big Spring & Yes \\
7 & Big Spring & Big Spring & Yes \\
23 & Hodgson Mill Spring & Hodgson Mill Spring & Yes \\
34 & Mammoth Spring & Mammoth Spring & Yes \\
38 & Mammoth Spring & Mammoth Spring & Yes \\
12 & Greer Spring & Greer Spring & Yes \\
\hline
\end{tabular}

\section{Linear discriminant analysis model one run 2 output.}

\begin{tabular}{cccc}
\hline ID \# & Actual Basin & Placed Basin & Correct? \\
\hline 9 & Big Spring & Big Spring & Yes \\
16 & Greer Spring & Greer Spring & Yes \\
27 & Hodgson Mill Spring & Hodgson Mill Spring & Yes \\
34 & Mammoth Spring & Mammoth Spring & Yes \\
7 & Big Spring & Big Spring & Yes \\
13 & Greer Spring & Greer Spring & Yes \\
$26 *$ & Hodgson Mill Spring & Hodgson Mill Spring & Yes \\
37 & Mammoth Spring & Mammoth Spring & Yes \\
\hline
\end{tabular}




\begin{tabular}{cccc}
\multicolumn{4}{c}{ Linear discriminant analysis model one run 3 output } \\
\hline ID \# & Actual Basin & Placed Basin & Correct? \\
\hline 1 & Big Spring & Big Spring & Yes \\
20 & Greer Spring & Greer Spring & Yes \\
23 & Hodgson Mill Spring & Hodgson Mill Spring & Yes \\
33 & Mammoth Spring & Mammoth Spring & Yes \\
2 & Big Spring & Big Spring & Yes \\
11 & Greer Spring & Greer Spring & Yes \\
27 & Hodgson Mill Spring & Hodgson Mill Spring & Yes \\
36 & Mammoth Spring & Mammoth Spring & Yes \\
\hline
\end{tabular}

\begin{tabular}{cccc}
\multicolumn{4}{c}{ Linear discriminant analysis model two run 1 output } \\
\hline ID \# & Actual Basin & Placed Basin & Correct? \\
\hline 8 & Big Spring & Big Spring & Yes \\
20 & Greer Spring & Greer Spring & Yes \\
23 & Hodgson Mill Spring & Hodgson Mill Spring & Yes \\
34 & Mammoth Spring & Mammoth Spring & Yes \\
7 & Big Spring & Big Spring & Yes \\
12 & Greer Spring & Greer Spring & Yes \\
27 & Hodgson Mill Spring & Hodgson Mill Spring & Yes \\
38 & Mammoth Spring & Mammoth Spring & Yes \\
\hline
\end{tabular}


Linear discriminant analysis model two run 2 output

\begin{tabular}{cccc}
\hline ID \# & Actual Basin & Placed Basin & Correct? \\
\hline 9 & Big Spring & Big Spring & Yes \\
16 & Greer Spring & Greer Spring & Yes \\
26 & Hodgson Mill Spring & Hodgson Mill Spring & Yes \\
34 & Mammoth Spring & Mammoth Spring & Yes \\
7 & Big Spring & Big Spring & Yes \\
13 & Greer Spring & Greer Spring & Yes \\
27 & Hodgson Mill Spring & Hodgson Mill Spring & Yes \\
8 & Mammoth Spring & Mammoth Spring & Yes \\
\hline
\end{tabular}

Linear discriminant analysis model two run 3 output

\begin{tabular}{cccc}
\hline ID \# & Actual Basin & Placed Basin & Correct? \\
\hline 1 & Big Spring & Big Spring & Yes \\
11 & Greer Spring & Greer Spring & Yes \\
23 & Hodgson Mill Spring & Hodgson Mill Spring & Yes \\
$\mathbf{3 3}$ & Mammoth Spring & Hodgson Mill Spring & No \\
2 & Big Spring & Big Spring & Yes \\
20 & Greer Spring & Greer Spring & Yes \\
27 & Hodgson Mill Spring & Hodgson Mill Spring & Yes \\
8 & Mammoth Spring & Mammoth Spring & Yes \\
\hline
\end{tabular}




\begin{tabular}{|c|c|c|c|c|}
\hline Date & Sample ID & Spring Name & Mahalanobis Distance & P-value \\
\hline $6 / 2 / 2019$ & 1 & Big Spring & 5.34758 & 0.8668 \\
\hline $6 / 15 / 2019$ & 2 & Big Spring & 2.48304 & 0.9911 \\
\hline $6 / 30 / 2019$ & 3 & Big Spring & 2.19886 & 0.9946 \\
\hline $7 / 13 / 2019$ & 4 & Big Spring & 2.18864 & 0.9947 \\
\hline $7 / 20 / 2019$ & 5 & Big Spring & 2.01945 & 0.9962 \\
\hline $7 / 27 / 2019$ & 6 & Big Spring & 1.84245 & 0.9974 \\
\hline $8 / 24 / 2019$ & 7 & Big Spring & 1.98106 & 0.9965 \\
\hline 9/7/2019 & 8 & Big Spring & 1.98106 & 0.9965 \\
\hline $9 / 28 / 2019$ & 9 & Big Spring & 3.72653 & 0.9588 \\
\hline $10 / 13 / 2019$ & 10 & Big Spring & 3.44811 & 0.9688 \\
\hline $6 / 2 / 2019$ & 11 & Greer Spring & 5.71283 & 0.8388 \\
\hline $6 / 15 / 2019$ & 12 & Greer Spring & 3.258 & 0.9747 \\
\hline $6 / 30 / 2019$ & 13 & Greer Spring & 2.01043 & 0.9963 \\
\hline $7 / 13 / 2019$ & 14 & Greer Spring & 1.16386 & 0.9997 \\
\hline $7 / 20 / 2019$ & 15 & Greer Spring & 0.30931 & 1 \\
\hline $7 / 27 / 2019$ & 16 & Greer Spring & 0.1136 & 1 \\
\hline $8 / 24 / 2019$ & 17 & Greer Spring & 0.13881 & 1 \\
\hline 9/7/2019 & 18 & Greer Spring & 0.51187 & 1 \\
\hline $9 / 28 / 2019$ & 19 & Greer Spring & 0.04321 & 1 \\
\hline $10 / 13 / 2019$ & 20 & Greer Spring & 0.22023 & 1 \\
\hline 6/2/2019 & 21 & Mammoth Spring & 5.40935 & 0.8622 \\
\hline $6 / 15 / 2019$ & 22 & Mammoth Spring & 2.82708 & 0.9852 \\
\hline $6 / 30 / 2019$ & 23 & Mammoth Spring & 2.39774 & 0.9923 \\
\hline $7 / 13 / 2019$ & 24 & Mammoth Spring & 0.83914 & 0.9999 \\
\hline $7 / 20 / 2019$ & 25 & Mammoth Spring & 0.7428 & 1 \\
\hline $7 / 27 / 2019$ & 26 & Mammoth Spring & 0.76707 & 0.9999 \\
\hline $8 / 24 / 2019$ & 27 & Mammoth Spring & 1.45956 & 0.9991 \\
\hline 9/7/2019 & 28 & Mammoth Spring & 1.4541 & 0.9991 \\
\hline $9 / 28 / 2019$ & 29 & Mammoth Spring & 0.8388 & 0.9999 \\
\hline $10 / 13 / 2019$ & 30 & Mammoth Spring & 4.09497 & 0.943 \\
\hline $6 / 2 / 2019$ & 31 & Hodgson Mill Spring & 0.94056 & 0.9999 \\
\hline $6 / 15 / 2019$ & 32 & Hodgson Mill Spring & 0.67865 & 1 \\
\hline $6 / 30 / 2019$ & 33 & Hodgson Mill Spring & 0.62887 & 1 \\
\hline $7 / 13 / 2019$ & 34 & Hodgson Mill Spring & 0.77851 & 0.9999 \\
\hline $7 / 20 / 2019$ & 35 & Hodgson Mill Spring & 1.14326 & 0.9997 \\
\hline $7 / 27 / 2019$ & 36 & Hodgson Mill Spring & 1.50963 & 0.9989 \\
\hline $8 / 24 / 2019$ & 37 & Hodgson Mill Spring & 3.20408 & 0.9762 \\
\hline 9/7/2019 & 38 & Hodgson Mill Spring & 1.45216 & 0.9991 \\
\hline $9 / 28 / 2019$ & 39 & Hodgson Mill Spring & 1.57988 & 0.9987 \\
\hline $10 / 13 / 2019$ & 40 & Hodgson Mill Spring & 4.55487 & 0.9189 \\
\hline
\end{tabular}

